\title{
CARBONIZER TESTS WITH LAKELAND FEEDSTOCKS
}

\author{
Phase 2 Task 4 Topical Report By: \\ C. Lu \\ Z. Fan \\ R. Froehlich \\ A. Robertson
}

Issued September 2003

U.S. Department of Energy

Contract No: DE-AC21-86MC21023

SECOND GENERATION

PRESSURIZED FLUIDIZED BED RESEARCH AND DEVELOPMENT

Foster Wheeler Development Corporation

12 Peach Tree Hill Road

Livingston, New Jersey 07039 


\section{DISCLAIMER}

"This report was prepared as an account of work sponsored by an agency of the United States Government. Neither the United States Government nor any agency thereof, nor any of their employees, makes any warranty, express or implied, or assumes any legal liability or responsibility for the accuracy, completeness, or usefulness of any information, apparatus, product, or process disclosed, or represents that its use would not infringe upon privately owned rights. Reference herein to any specific commercial product, process, or service by trade name, trademark, manufacturer, or otherwise does not necessarily constitute or imply its endorsement by the United States Government or any agency thereof. The views and opinions of authors expressed herein do not necessarily state or reflect those of the United States Government or any agency thereof." 


\section{ABSTRACT}

Research has been conducted under United States Department of Energy Contract (USDOE) DE-AC21-86MC21023 to develop a new type of coal-fired plant for electric power generation. This new type of plant, called a Second Generation Pressurized Fluidized Bed Combustion Plant $\left(2^{\text {nd }}\right.$ Gen PFB), offers the promise of efficiencies greater than $48 \%$, with both emissions and a cost of electricity that are significantly lower than those of conventional pulverized coal-fired (PC) plants with wet flue gas desulfurization/scrubbers.

The $2^{\text {nd }}$ Gen PFB plant incorporates the partial gasification of coal in a carbonizer, the combustion of carbonizer char in a pressurized circulating fluidized (PCFB) bed boiler, and the combustion of carbonizer syngas in a topping combustor to achieve gas turbine inlet temperatures of $2700^{\circ} \mathrm{F}$ and higher.

Under the USDOE Clean Coal V Demonstration Plant Program, a nominal 260 MWe plant demonstrating $2^{\text {nd }}$ Gen PFB technology has been proposed for construction at the McIntosh Power Plant of the City of Lakeland, Florida. In the September-December 1997 time period, four test runs were conducted in Foster Wheeler's 12-inch diameter carbonizer pilot plant in Livingston New Jersey to ascertain carbonizer performance characteristics with the Kentucky No 9 coal and Florida limestone proposed for use in the Lakeland plant. The tests were of a shortterm nature exploring carbonizer carbon conversions, sulfur capture efficiencies and syngas alkali levels. The tests were successful; observed carbonizer performance was in agreement with predictions and no operating problems, attributed to the planned feedstocks, were encountered. The results of the four test runs are reported herein. 


\section{Table of Contents}

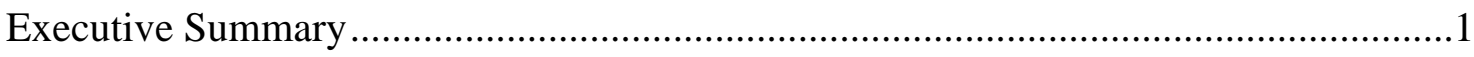

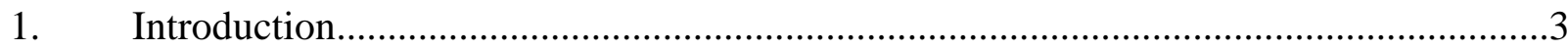

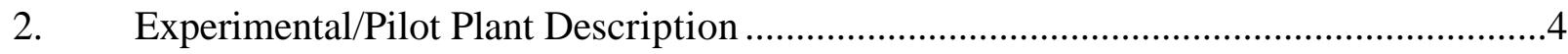

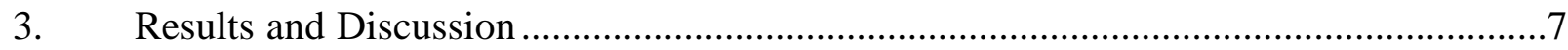

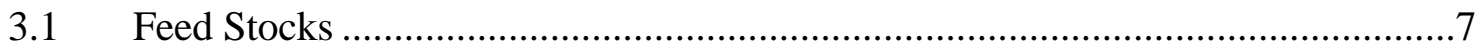

3.2 Sorbent Feed Size and Bed Agglomeration............................................... 17

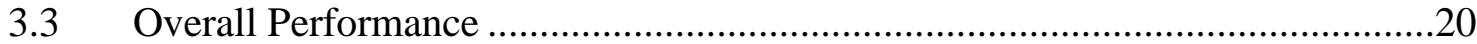

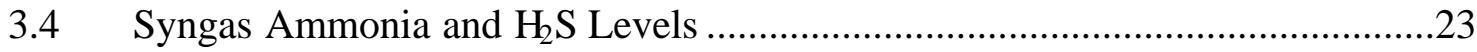

3.5 Bed Composition ....................................................................................29

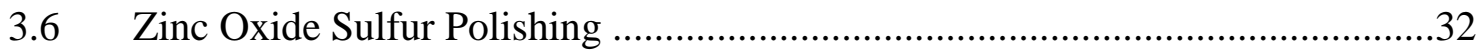

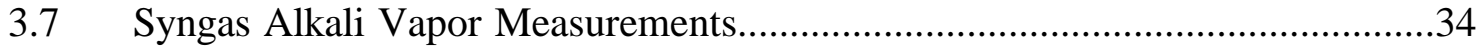

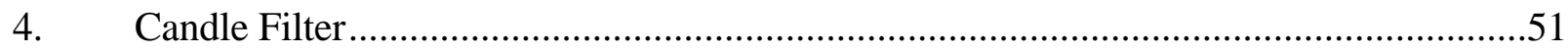

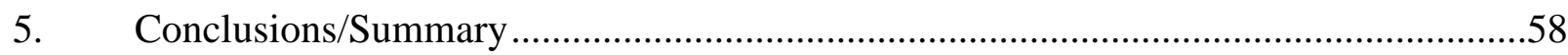

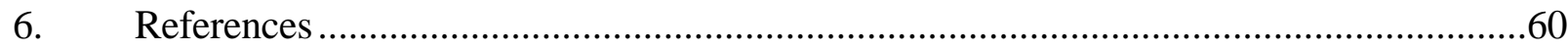

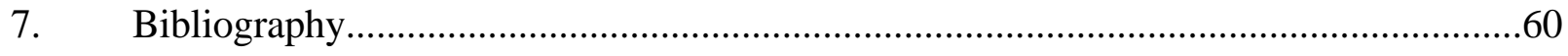

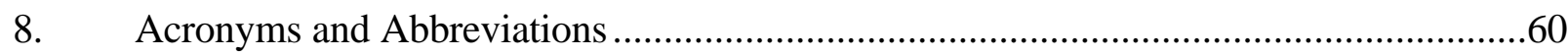




\section{$\underline{\text { Lists of Graphical Materials }}$}

\section{Figures}

$2.1 \quad$ 12-in. Carbonizer for Lakeland Tests .......................................................................

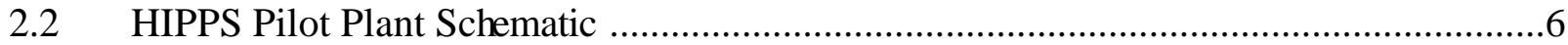

3.1.1 Size Distribution of Limestone Feed Samples from Test Run TR7 ...............................15

3.1.2 Size Distribution of Coal Feed Samples from Test Run TR7 …………........................16

3.2.1 Agglomeration Experienced in Carbonizer Test Run TR4 ……….................................18

3.2.2 TR6 Bed Temperatures and Cooler Flows...................................................................19

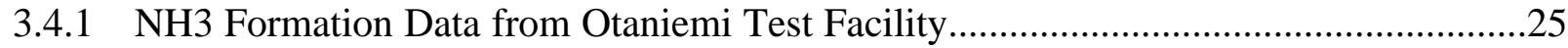

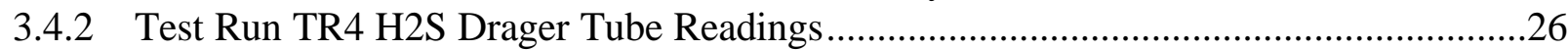

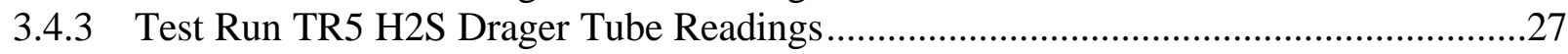

3.5.1 TR7.2 Bed Char Content via Post Run Inspection ........................................................30

3.5.2 TR7.2 Char Carbon Content via Post Run Inspection ...................................................31

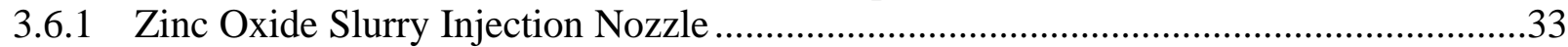

3.7.1 Syngas Equilibrium Total Alkali Vapor Estimate ………................................................35

3.7.2 Location of Carbonizer Syngas Alkali Measurements ......................................................36

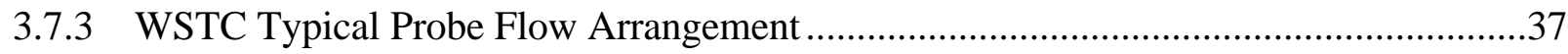

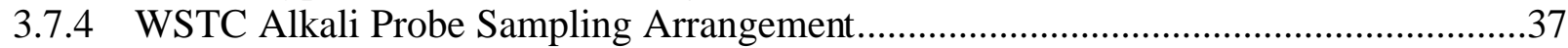

3.7.5 WSTC Probe with Alkali Sampling Tip ………...........................................................

3.7.6 Syngas Alkali Vapor Level Versus Temperature ………………..................................43

3.7.7 Syngas Alkali Vapor Level Versus Temperature (Expanded Scale) ...............................44

3.7.8 Alkali Results Extracted from [3-1] .........................................................................47

3.7.9 Predicted and Observed Alkali Data in Oxidizing PFB Flue Gas from [3-3] ................50

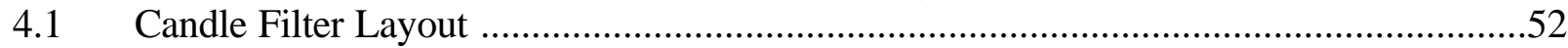

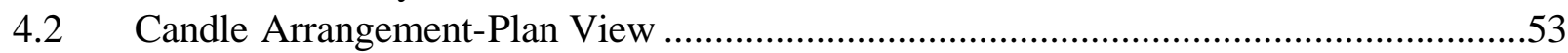

4.3 Typical Filter Performance During Test Run TR5 (22 Candles)....................................55

4.4 Typical filter Performance During Test Run TR7 (10 Candles)....................................56 


\section{Tables}

3.1.1 Typical Coal Analysis for Test Runs TR4 through TR7 ..........................................8

3.1.2 Typical Coal Ash Analysis for Test Runs TR4 through TR7 ......................................9

3.1.3 Typical Coke Analysis for Test Point TR7.1 .................................................... 10

3.1.4 Typical Coke Ash Analysis for Test Point TR7.1 ...............................................11

3.1.5 Typical Limestone Analysis for Test Runs TR4 and TR5 ......................................12

3.1.6 Typical Limestone Analysis for Test Runs TR6 and TR7 .....................................13

3.1.7 Typical Limestone Size Distribution for Test Runs TR4 and TR5 ..........................14

3.3.1 Lakeland Carbonizer Test Results ...................................................................21

3.3.2 Carbonizer Syngas Composition..........................................................................22

3.3.3 Carbon Content of Carbonizer Streams ..............................................................22

3.4.1 Syngas Ammonia Analyses of GC Data ..........................................................23

3.4.2 Typical NH3 and HCN Contents of the Product Gas w/Different Feedstocks ..............24

3.4.3 Carbonizer Sulfur Capture Efficiency............................................................28

3.7.1 Alkali Sampling Summary for Lakeland Test TR4 through TR7 (Sept. - Dec. 1997) ..41

3.7.2 Alkali Sample Chemical Analysis Summary for Lakeland Test

TR4 through TR7 (Sept. - Dec. 1997) ..............................................................42

3.7.3 Gasifier and Feedstock Data Extracted from [3-1] ................................................46

3.7.4 Wakamatsu Fuel and Test Conditions from [3-3] ............................................48

3.7.5 Wakamatsu Oxidizing PFB Flue Gas and Alkali Results from [3-3] ..........................49

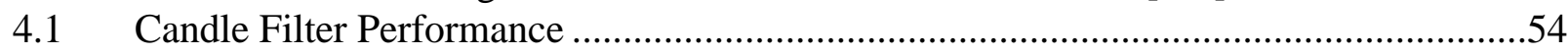




\section{Executive Summary}

The Kentucky No 9 coal and Florida limestone proposed for use in the Lakeland Clean Coal V Second Generation Pressurized Fluidized Bed ( $2^{\text {nd }}$ Gen PFB) Demonstration Plant were tested in Foster Wheeler's carbonizer pilot plant in the September-December 1997 time period. Four relatively short-term test runs were conducted and the feedstocks caused no operating problems in the carbonizer or its ceramic candle filter. In the first two runs a fine limestone feed size (d50 $\approx 150$ micron) was used, whereas in the second two runs a coarser minus $1 / 8 \mathrm{in}$. feed was employed. Since the carbonizer was operated on a once-through basis (no recycle of elutriated fines back to the bed), most of the fine sorbent elutriated and left behind a predominantly char bed. With less sorbent in the bed, the fine feed sulfur capture efficiency was less that that of the coarse feed (about 931/2 versus 95\%); and the coarse feed size 1/8" x 300 micron is recommended for the Lakeland demonstration plant carbonizer.

Agglomeration was experienced in the carbonizer during the tests and an examination of operating data traced the cause to inadequate fluidization around the feed pipe. By raising the velocity to $2 \mathrm{ft} / \mathrm{sec}$ in the drain annulus that surrounds the feed pipe, agglomeration was eliminated.

The carbon conversions and gas yields observed in the tests were in accordance with the performance predicted by Foster Wheeler's proprietary carbonizer computer model. A portion of the coal nitrogen that is released in the carbonizer is converted to ammonia. Previous testing has shown this conversion to be a function of the feedstocks and operating conditions. Ammonia conversion with the Lakeland coal and limestone ranged from 6.7 to $22.5 \%$ of the coal nitrogen released in the carbonizer.

Tests were also conducted to determine what increases in sulfur capture efficiency could be achieved by injecting zinc oxide ( $\mathrm{ZnO})$, a sulfur capturing/polishing agent, into the carbonizer syngas upstream of the candle filter. The $\mathrm{ZnO}$ was injected as a 5 to $15 \%$ by weight water slurry into the gas stream at the top of the carbonizer while the unit operated with the Lakeland 1.4\% sulfur coal and Florida limestone. The tests showed that large amounts of water injection can cause sulfur, already captured as calcium sulfide, to be released to the syngas from entrained particulate matter and the candle filter ash cake. By using the $15 \%$ by weight slurry it was possible to increase the carbonizer sulfur capture efficiency from $93.7 \%$ to over $98 \%$. Although this was achieved at a $\mathrm{Zn}$ to syngas sulfur molar feed ratio of 6.5 , lower feed ratios would be required if the injection were done with more dense slurries or by using a dry injection system.

Gas turbine limits on vapor phase alkali levels are in the parts per billion range; because their levels are low and gas temperatures and pressures are high, measurement of alkali vapor levels is difficult to make. Using an extractive probe that was designed and supplied by the Westinghouse Science and Technology Center (WSTC) together with their laboratory handling/analyses procedures, alkali measurements were conducted by Foster Wheeler in the Livingston carbonizer pilot plant. The measurements were made downstream of the ceramic candle filter with the carbonizer operating at proposed Lakeland conditions. The vapor phase alkali levels measured with the WSTC probe decreased, as expected, with decreasing gas 
temperature. Even though the alkali levels were very low, the temperature trend exhibited minimal scatter and the data indicates carbonizer syngas alkali levels should be less than 20 ppbw at $1200^{\circ} \mathrm{F}$, a value that should be acceptable to a gas turbine. The ceramic candle filter operated at about $1300 \mathrm{EF}$. During the first two runs, the filter operated without a pre-cleaning cyclone and, to accommodate the higher solids loading, a $1.9 \mathrm{ft} / \mathrm{min}$ candle face velocity was used ( 22 candles were installed in the filter). In the second run, a pre-cleaning cyclone was installed, and the face velocity was increased to about $4 \mathrm{ft} / \mathrm{min}$ by reducing the number of candles to 10. In all four runs the filter performed successfully showing no signs of blinding, bridging, or ash hopper agglomeration.

Although the carbonizer tests were of a relatively short duration, the feedstocks planned for the Lakeland plant caused no operating problems and their carbon conversions, syngas yields and heating values, and sulfur capture efficiencies agreed with the performance predicted by Foster Wheeler's proprietary carbonizer computer model. 


\section{$\underline{1.0}$ Introduction}

Under the U.S. Department of Energy Clean Coal V Demonstration Plant Program, a nominal 260 MWe plant demonstrating $2^{\text {nd }}$ Gen PFB technology has been proposed for construction at the McIntosh Power Plant of the City of Lakeland, Florida. In this new type of plant coal is partially gasified in a jetting/bubbling fluidized bed reactor called the carbonizer. The carbonizer produces a syngas that fuels a gas turbine and a char residue that fuels a pressurized circulating fluidized bed (PCFB) boiler which in turn powers a steam turbine. The PCFB boiler operates with relatively high excess air and the unused oxygen in its flue gas supports the combustion of the carbonizer syngas in a gas turbine topping combustor. Before these gases reach the topping combustor they are stripped of entrained particulate by barrier type candle filters.

The carbonizer, PCFB boiler, and candle filters are the new technologies of the $2^{\text {nd }}$ Gen PFB plant and, although each has been successfully tested at the pilot plant scale, operations to date have been limited to a few specific fuels. The coal and limestone sorbent proposed for use in the Lakeland plant are new untested feedstocks. In the September-December 1997 time period, four test runs were conducted in Foster Wheeler's 12-inch diameter carbonizer pilot plant carbonizer in Livingston, New Jersey, with the Kentucky No 9 coal and Florida limestone proposed for the Lakeland plant. The tests were of a short-term nature and were conducted to:

1. determine if the feedstocks caused any operating problems in the carbonizer or candle filter;

2. confirm that the feedstocks performed (carbon conversion, syngas yields and heating values, sulfur capture efficiency, etc.,) as predicted by Foster Wheeler's proprietary carbonizer computer models.

3. determine if the carbonizer would operate successfully with the fine limestone feed ( $\mathrm{d} 50 \approx 150$ micron) proposed for the Lakeland PCFB boiler (essentially all previous carbonizer testing had been conducted with a $1 / 8$ " x 0 feed with $\mathrm{d} 50 \approx 600$ micron).

4. investigate the feasibility of injecting zinc oxide $(\mathrm{ZnO})$ into the carbonizer syngas upstream of the candle filter to increase the carbonizer sulfur capture efficiency over and above that provided by in-bed limestone injection.

5. measure syngas alkali vapor levels exiting the candle filter 


\subsection{Experimental/Pilot Plant Description}

The Lakeland tests were conducted in the refractory lined, 12-inch diameter carbonizer/ pyrolyzer and pilot plant shown in Figures 2.1 and 2.2. Coal, limestone, and air entered as a vertical central jet at the base of the unit. The unit typically operated with about a 26-feet deep bed with syngas exiting from a 4-inch ID top radial nozzle. The char-sorbent residue generated in the process drained from the bottom through a 1-7/8 inch wide annulus that surrounded the feed pipe. A packed bed cooling section below the annulus cooled the residue with counterflowing nitrogen. Thereafter the residue was withdrawn in batches through a 4-inch pipeline to a lock hopper that was used to depressure the material. A bed overflow nozzle provided at the top of the bed was not used during these tests.

The syngas exited from the top of the carbonizer, passed through a WSTC ceramic candle filter that essentially removed all gas entrained particulate, an orifice plate that depressured the gas to ambient, a dry quench water spray tower that cooled the syngas to approximately $350 \mathrm{EF}$, a demister that removed any gas entrained water droplets, a baghouse filter, and a natural gas fired incinerator that burned the syngas and exhausted to the atmosphere. During the first two runs there was no precleaning cyclone between the carbonizer and the ceramic candle filter, and the latter operated with 22 candles yielding a syngas candle face velocity of about 1.9 feet per minute (fpm). In the last two runs a precleaning cyclone was added, and the particulate collected by the cyclone drained through a nitrogen aerated loop seal to the surge hopper beneath the filter. With the particulate loading to the filter reduced, the number of candles was reduced to 10 , which raised the candle face velocity to about 4 feet per minute. Within the filter the entrained particulate collected on the outside of the ceramic candles and the accumulation, called the filter cake, was removed/blown off the candles by intermittent pulses of nitrogen back flowing through the unit.

Blown free of the candles, the filter cake fell to the bottom and drained to a surge hopper provided directly below the filter vessel. Steam cooled tube coils provided in the surge hopper cooled the draining material. A lock hopper under the surge hopper was used to depressure the material and facilitate their pneumatic transport by nitrogen to a second baghouse; the drains from both baghouses were collected in drums and weighed before removal to storage.

Coal and limestone were pneumatically transported to and injected into the carbonizer as a blend via a lock hopper feed system. The air-to-coal feed ratio is the primary determinant of the carbonizer operating temperature and, since the pilot plant utilizes an orifice plate to depressure the syngas, their total flow rate/throughput determines the carbonizer operating pressure. 


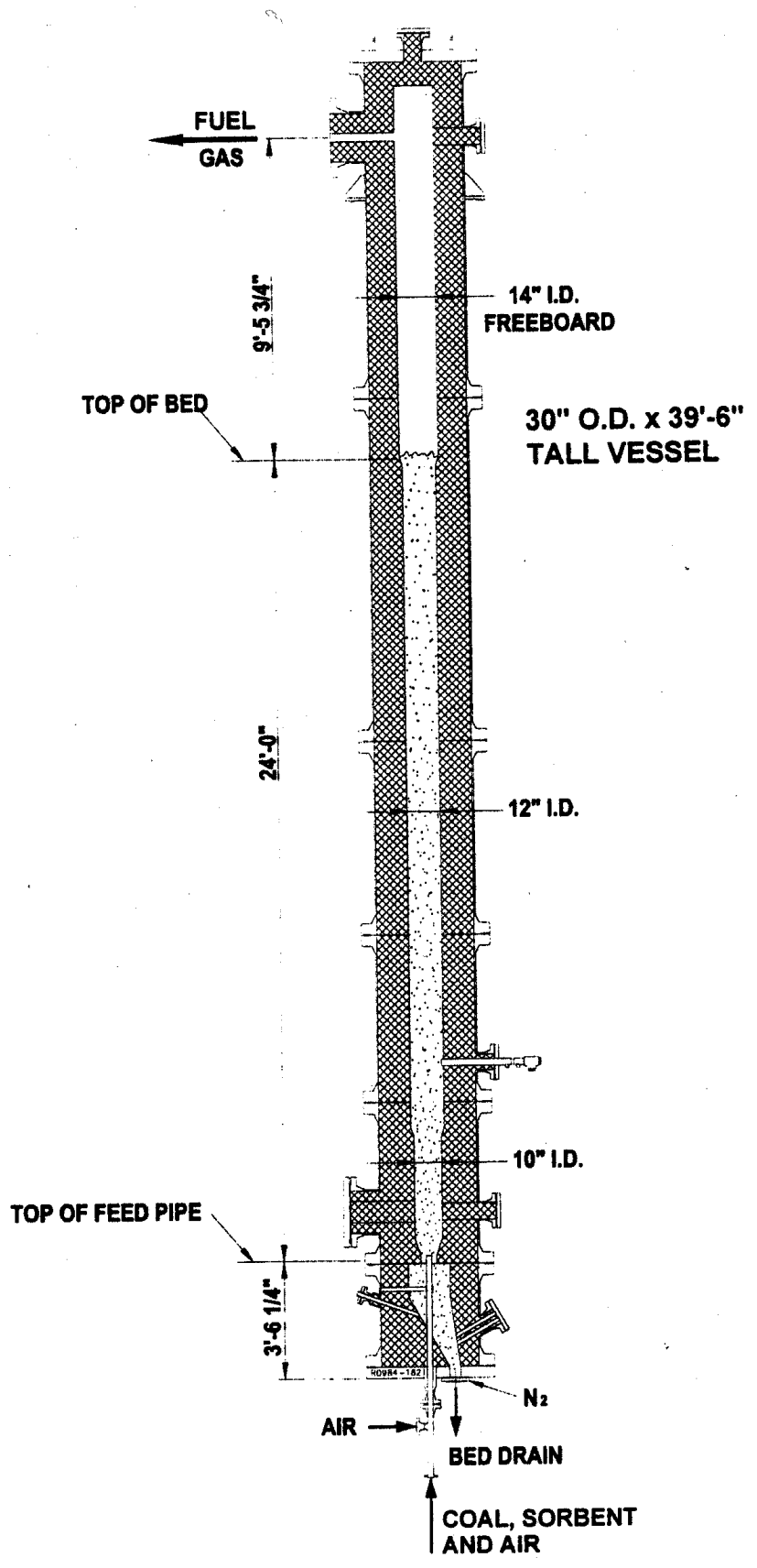

Figure 2.1 12-in. Carbonizer for Lakeland Tests 


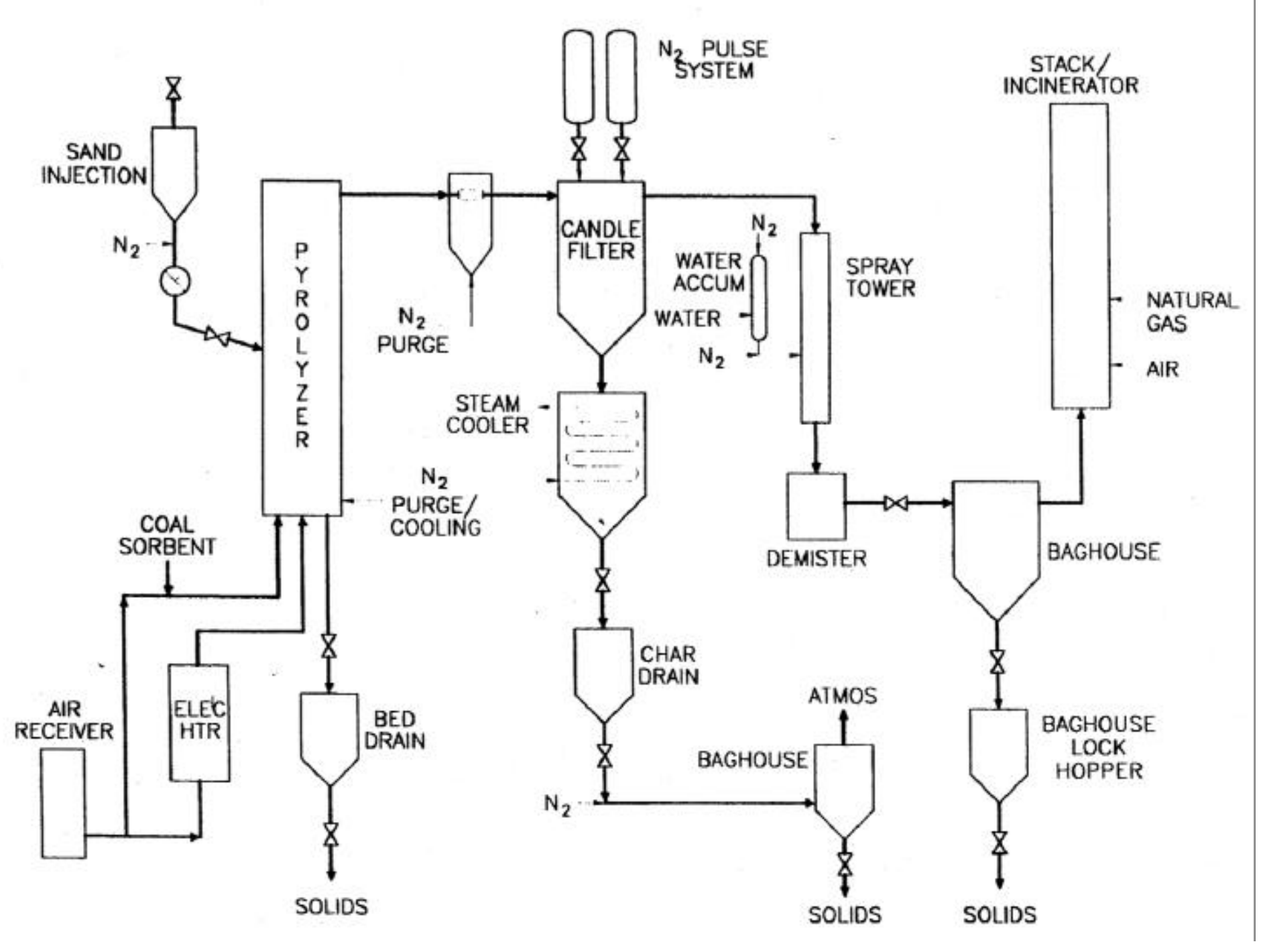

Figure 2.2 HIPPS Pilot Plant Schematic 


\subsection{Results and Discussion}

\section{1 $\quad$ Feedstocks}

A total of four carbonizer test runs (TR4 through TR7) were performed during the SeptemberDecember 1997 time period. Tables 3.1.1 through 3.1.7 and Figures 3.1.1 and 3.1.2 present typical analyses and particle size distributions of the feedstocks used in the tests. The limestone used during the runs came from two different shipments from the same supplier, Florida Crushed Stone Co. Noting that the second shipment had a significantly higher silica content than the first, a typical analysis has been presented for each shipment. With regard to the Kentucky No 9 coal, it had a 1.4\% sulfur content and, depending upon the sample analyzed, the Free Swelling Index varied from a low of 2.0 to a high of 4.5. 
Table 3.1.1 Typical Coal Analysis for Test Runs TR4 through TR7

\section{FOSTER WHEELER DEVELOPMENT CORPOAATION FUEL ANALYSIS}

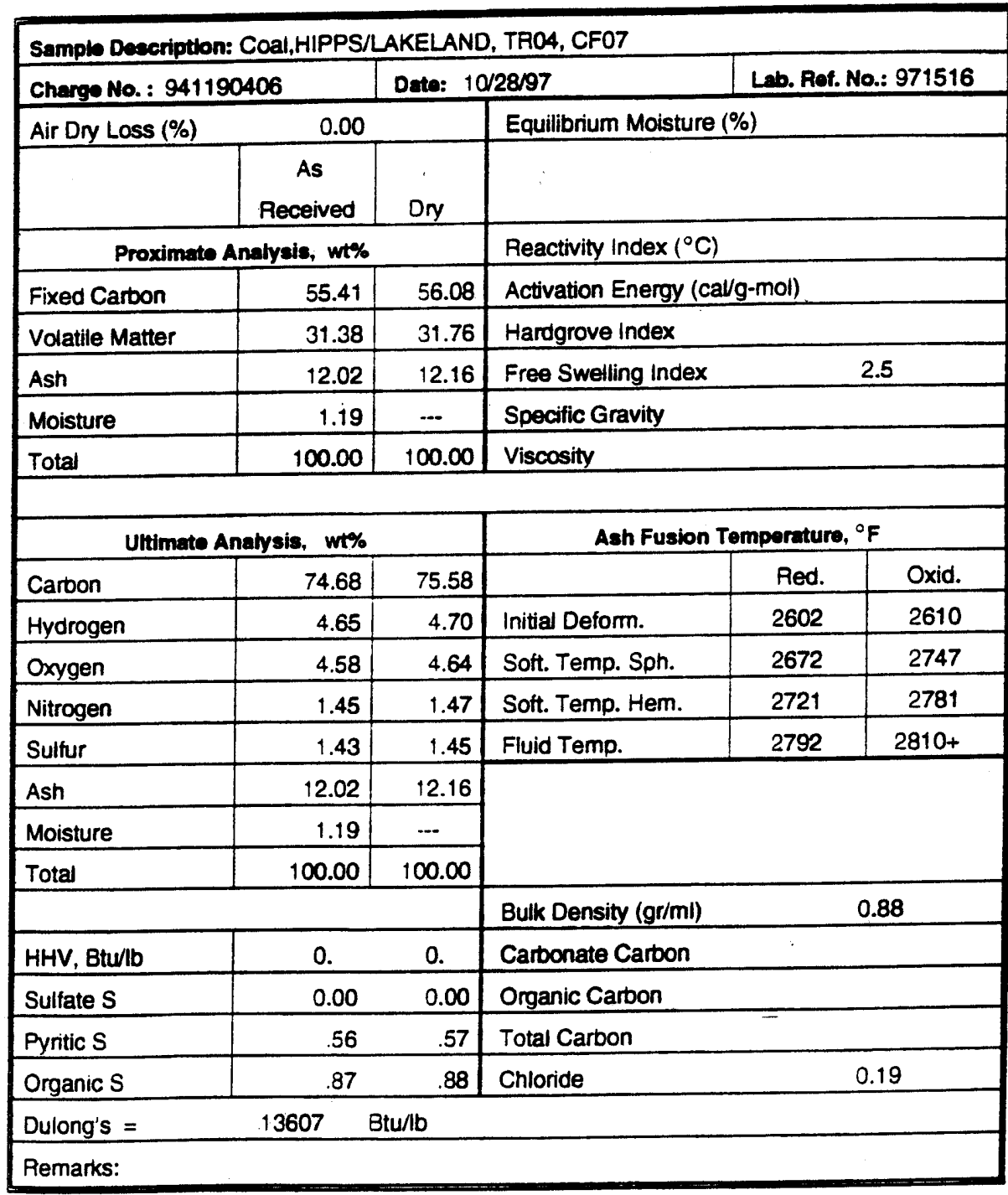

Analyst:

Approved: 
Table 3.1.2 Typical Coal Ash Analysis for Test Runs TR4 through TR7

\section{FOSTER WHEELER DEVELOPMENT CORPORATION ASHDEPOSTT ANALYSIS}

Sample Description: Coal,HIPPS/LAKELAND, TR04, CF07

Charge No.: $941190406 \quad$ Date: 12-19-1997 Lab. Ref. No. : 971516

\begin{tabular}{|c|c|c|c|c|c|}
\hline Anabite & As Element & Factor & & As Oxide & Anatyt sectared \\
\hline Silicon & Si & 2.140 & Silicon Dioxide & 50.8 & X-RAY \\
\hline Aluminum & $\mathrm{Al}$ & 1.890 & Aluminum Oxide & 29.8 & X-RAY \\
\hline Titanium & $\pi$ & 1.668 & Titanium Dioxide & 1.6 & $X$-RAY \\
\hline Iron & $\mathrm{Fe}$ & 1.430 & Ferric Oxide & 10.1 & $X$-AAY \\
\hline Calcium & $\mathrm{Ca}$ & 1.399 & Calcium Oxide & 1.9 & $X$-RAY \\
\hline Magnesium : & $\mathrm{Mg}$ & 1.658 & Magnesium Oxjde & 1.0 & $X$-RAY \\
\hline Sodium & $\mathrm{Na}$ & 1.348 & Sodium Oxide & $<0.1$ & X-RAY \\
\hline Potassium & $K$ & 1.205 & Potassium Oxide & 2.6 & X-RAY \\
\hline Sulfur & $\mathrm{s}$ & 2.500 & Sulfur Trioxide & 1.1 & $X$-RAY \\
\hline Phosphorus & $P$ & 2.291 & Phos. Pentoxide & 0.2 & X-RAY \\
\hline Nickel & $\mathrm{Ni}$ & 1.273 & Nickel(ic) oxide & & \\
\hline Vanadium & $v$ & 1.785 & Vand. Pentoxide & & \\
\hline Manganese & $\mathrm{Mn}$ & 1.583 & Mangan. Dioxide & & \\
\hline Chromium & $\mathrm{Cr}$ & 1.461 & Chromic Oxide & & \\
\hline Molybdenum: & Mo & 1.500 & Moly. Trioxide & & \\
\hline Zinc & $\mathrm{Zn}$ & 1.245 & Zinc Oxide & & \\
\hline Lead & $\mathrm{Pb}$ & 1.077 & Lead Oxide & & \\
\hline $\operatorname{Tin}$ & Sn & 1.270 & Stannic Oxide & & \\
\hline Copper & $\mathrm{Cu}$ & 1.252 & Cupric Oxide & & \\
\hline Silver & $\mathrm{Ag}$ & 1.074 & Silver Oxide & & \\
\hline Antimony & Sb & 1.197 & Antimony Trioxide & & \\
\hline Chlorine & $\mathrm{Cl}$ & 1.000 & Chloride & & \\
\hline \multirow[t]{3}{*}{ Remarks: } & & & Total Percentage & 99.1 & \\
\hline & & & & Analyst: & \\
\hline & & & & Approved: & \\
\hline
\end{tabular}


Table 3.1.3 Typical Coke Analysis for Test Point TR7.1

FOSTER WHEELEA DEVELOPMENT CORPORATION FUEL ANALYSIS

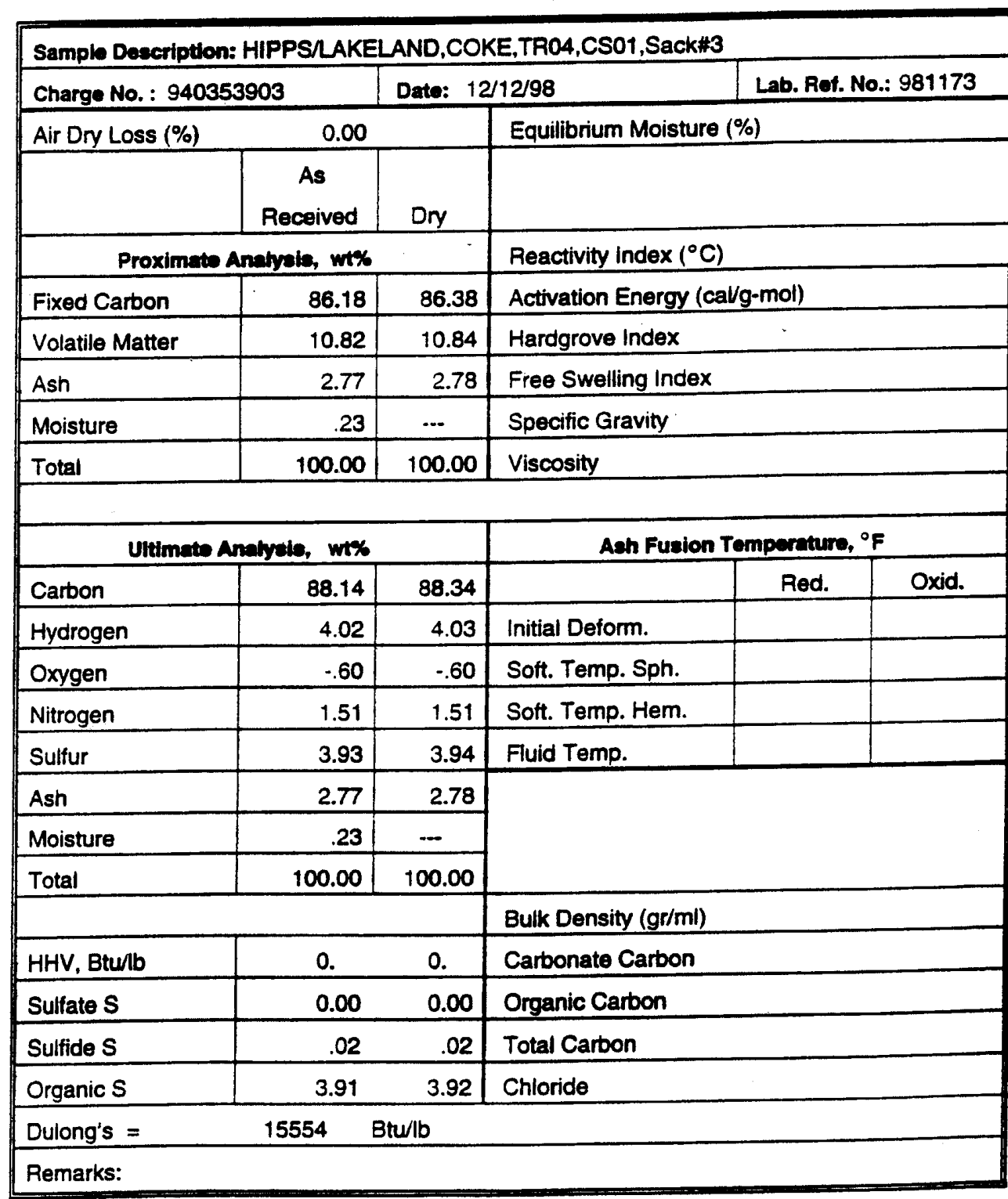

Analyst:

Approved:

$30-5$ L VISTC 
Table 3.1.4 Typical Coke Ash Analysis for Test Point TR7.1

\section{FOSTER WHEELER DEVELOPMENT CORPORATION ASH/DEPOSIT ANALYSIS}

Sample Description: HIPPS/LAKELAND,COKE,TR07,CS01,Sack\#3

Charge No. : 940353903

Date: 11-24-1998 Lab. Ref. No. : 981173

\begin{tabular}{|c|c|c|c|c|c|}
\hline Analyte & As Element & Factor & & As Oxide & Analyt. Mothod \\
\hline Silicon & Si & 2.140 & Silicon Dioxide & 37.5 & X-RAY \\
\hline Aluminum & $\mathrm{Al}$ & 1.890 & Aluminum Oxide & 13.5 & X-RAY \\
\hline Titanium & $\mathrm{Ti}$ & 1.668 & Titanium Dioxide & 0.9 & X-RAY \\
\hline Iron & $\mathrm{Fe}$ & 1.430 & Ferric Oxide & 12.3 & X-RAY \\
\hline Calcium & $\mathrm{Ca}$ & 1.399 & Calcium Oxide & 10.5 & X-RAY \\
\hline Magnesium : & $\mathrm{Mg}$ & 1.658 & Magnesium Oxide & 1.5 & X-RAY \\
\hline Sodium & $\mathrm{Na}$ & 1.348 & Sodium Oxide & 1.0 & X-RAY \\
\hline Potassium & $\mathrm{K}$ & 1.205 & Potassium Oxide & 2.2 & X-RAY \\
\hline Sulfur & $S$ & 2.500 & Sulfur Trioxide & 12.7 & $X$-RAY \\
\hline Phosphorus ! & $\mathbf{P}$ & 2.291 & Phos. Pentoxide & 0.2 & X-RAY \\
\hline Nickel & $\mathrm{Ni}$ & 1.273 & Nickel(ic) oxide & 1.7 & SEMIQUANT \\
\hline Vanadium & V & 1.785 & Vand. Pentoxide & 4.7 & SEMIQUANT \\
\hline Manganese ! & $\mathrm{Mn}$ & 1.583 & Mangan. Dioxide & & \\
\hline Chromium & $\mathrm{Cr}$ & 1.461 & Chromic Oxide & & \\
\hline Molybdenumi & Mo & 1.500 & Moly. Trioxide & & \\
\hline Zinc & Zn & 1.245 & Zinc Oxide & 0.1 & SEMIQUANT \\
\hline Lead & $\mathrm{Pb}$ & 1.077 & Lead Oxide & & \\
\hline Tin & Sn & 1.270 & Stannic Oxide & & \\
\hline Copper & $\mathrm{Cu}$ & 1.252 & Cupric Oxide & & \\
\hline Silver & $\mathrm{Ag}$ & 1.074 & Silver Oxide & & \\
\hline Antimony & $\mathrm{Sb}$ & 1.197 & Antimony Trioxide & & \\
\hline Chlorine & $\mathrm{Cl}$ & 1.000 & Chloride & & \\
\hline \multirow[t]{2}{*}{ Remarks: } & & & Total Percentage & 98.8 & \\
\hline & & & & Analyst: & 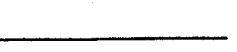 \\
\hline
\end{tabular}


Table 3.1.5 Typical Limestone Analysis for Test Runs TR4 and TR5

\section{FOSTER WHEELER DEVELOPMENT CORPORATION ASHDEPOST ANALYSIS}

Sample Description: Limestone,HIPPS/LAKELAND, TR04, \&F-06

Charge No. : $941190406 \quad$ Date: 12-19-1997 Lab. Ref. No. : 971520

\begin{tabular}{|c|c|c|c|c|c|}
\hline Analyte & As Elomont & Factor & & As Oxige & Analyt. Mothod \\
\hline Silicon & Si & 2.140 & Silicon Dioxide & 9.3 & X-RAY \\
\hline Aluminum & $\mathrm{Al}$ & 1.890 & Aluminum Oxide & 0.8 & $X$-RAY \\
\hline Titanium & $\mathrm{Ti}$ & 1.668 & Titanium Dioxide & NIL & X-RAY \\
\hline Iron & $\mathrm{Fe}$ & 1.430 & Ferric Oxide & 0.4 & X-RAY \\
\hline Calcium & $\mathrm{Ca}$ & 1.399 & Calcium Oxide & 88.0 & $X$-RAY \\
\hline Magnesium & $\mathrm{Mg}$ & 1.658 & Magnesium Oxide & 0.5 & $X$-RAY \\
\hline Sodium & $\mathrm{Na}$ & 1.348 & Sodium Oxide & $<0.1$ & $X$-RAY \\
\hline Potassium & $K$ & 1.205 & Potassium Oxide & 0.1 & $X$-RAY \\
\hline Sulfur & $\mathrm{S}$ & 2.500 & Sulfur Trioxide & 0.4 & $X$-RAY \\
\hline Phosphorus & $P$ & 2.291 & Phos. Pentoxide & 0.1 & X-RAY \\
\hline Nickel & $\mathrm{Ni}$ & 1.273 & Nickel(ic) oxide & & \\
\hline Vanadium & V & 1.785 & Vand. Pentoxide & & \\
\hline Manganese & Mn & 1.583 & Mangan. Dioxide & & \\
\hline Chromium & $\mathrm{Cr}$ & 1.461 & Chromic Oxide & & \\
\hline Molybdenum: & Mo & 1.500 & Moly. Trioxide & & \\
\hline Zinc & $\mathrm{Zn}$ & 1.245 & Zinc Oxide & & \\
\hline Lead & $\mathrm{Pb}$ & 1.077 & Lead Oxide & & \\
\hline Tin & Sn & 1.270 & Stannic Oxide & & \\
\hline Copper & $\mathrm{Cu}$ & 1.252 & Cupric Oxide & & \\
\hline Silver & $\mathrm{Ag}$ & 1.074 & Silver Oxide & & \\
\hline Antimony & $\mathrm{Sb}$ & 1.197 & Antimony Trioxide & 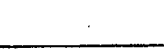 & \\
\hline Chlorine & $\mathrm{Cl}$ & 1.000 & Chloride & - & \\
\hline Remarks: & & & Total Percentage & 99.6 & \\
\hline LOI $=43.16 \%$ & & & & Analyst: & \\
\hline
\end{tabular}

Approved: 3R:A P LANT 
Table 3.1.6 Typical Limestone Analysis for Test Runs TR6 and TR7

\section{FOSTER WHEELER DEVELOPMENT CORPORATION ASHVEPOSTT ANALYSIS}

Sample Description: HIPPS/LLAKELAND, Limestone, TRO7-SF01

Charge No. : $940353905 \quad$ Date: 01-23-1998 Lab. Ref. No. : 971861

\begin{tabular}{|c|c|c|c|c|c|}
\hline Analyte & As Eloment & Factor & & As Oxide & Analyt. Method \\
\hline Silicon & $\mathrm{Si}$ & 2.140 & Silicon Dloxide & 19.5 & X-RAY \\
\hline Aluminum & Al & 1.890 & Aluminum Oxide & 4.8 & X-RAY \\
\hline Titanium & $\mathrm{Ti}$ & 1.668 & Titanium Dioxide & 0.2 & X-RAY \\
\hline Iron & $\mathrm{Fe}$ & 1.430 & Ferric Oxide & 1.9 & $X$-RAY \\
\hline Calcium & $\mathrm{Ca}$ & 1.399 & Calcium Oxide & 69.4 & X-RAY \\
\hline Magnesium & $\mathrm{Mg}$ & 1.658 & Magnesium Oxide & 0.9 & $X$-RAY \\
\hline Sodium & $\mathrm{Na}$ & 1.348 & Sodium Oxide & $<0.1$ & $X$-RAY \\
\hline Potassium & $\mathrm{K}$ & 1.205 & Potassium Oxide & 1.0 & X-RAY \\
\hline Sulfur & $\mathrm{s}$ & 2.500 & Sulfur Trioxide & 0.3 & X-RAY \\
\hline Phosphorus & $P$ & 2.291 & Phos. Pentoxide & 0.1 & X-RAY \\
\hline Nickel & $\mathrm{Ni}$ & 1.273 & Nickel(ic) oxide & & \\
\hline Vanadium & v & 1.785 & Vand. Pentoxide & & \\
\hline Manganese & $\mathrm{Mn}$ & 1.583 & Mangan. Dioxide & & \\
\hline Chromium & $\mathrm{Cr}$ & 1.461 & Chromic Oxide & & \\
\hline Molybdenum: & Mo & 1.500 & Moly. Trioxide & & \\
\hline Zinc & $\mathrm{Zn}$ & 1.245 & Zinc Oxide & & \\
\hline Lead & $\mathrm{Pb}$ & 1.077 & Lead Oxide & & \\
\hline Tin & Sn & 1.270 & Stannic Oxide & & \\
\hline Copper & $\mathrm{Cu}$ & 1.252 & Cupric Oxide & & \\
\hline Silver & $\mathrm{Ag}$ & 1.074 & Silver Oxide & & \\
\hline Antimony & Sb & 1.197 & Antimony Trioxide & & \\
\hline Chlorine & $\mathrm{Cl}$ & 1.000 & Chloride & & \\
\hline Remarks: & & & Total Percentage & 98.1 & \\
\hline LOH $=36.52 \%$ & & & & Analyst: & \\
\hline
\end{tabular}

Approved: 
Table 3.1.7 Typical Limestone Size Distribution for Test Runs TR4 and TR5

Sleve Analysis

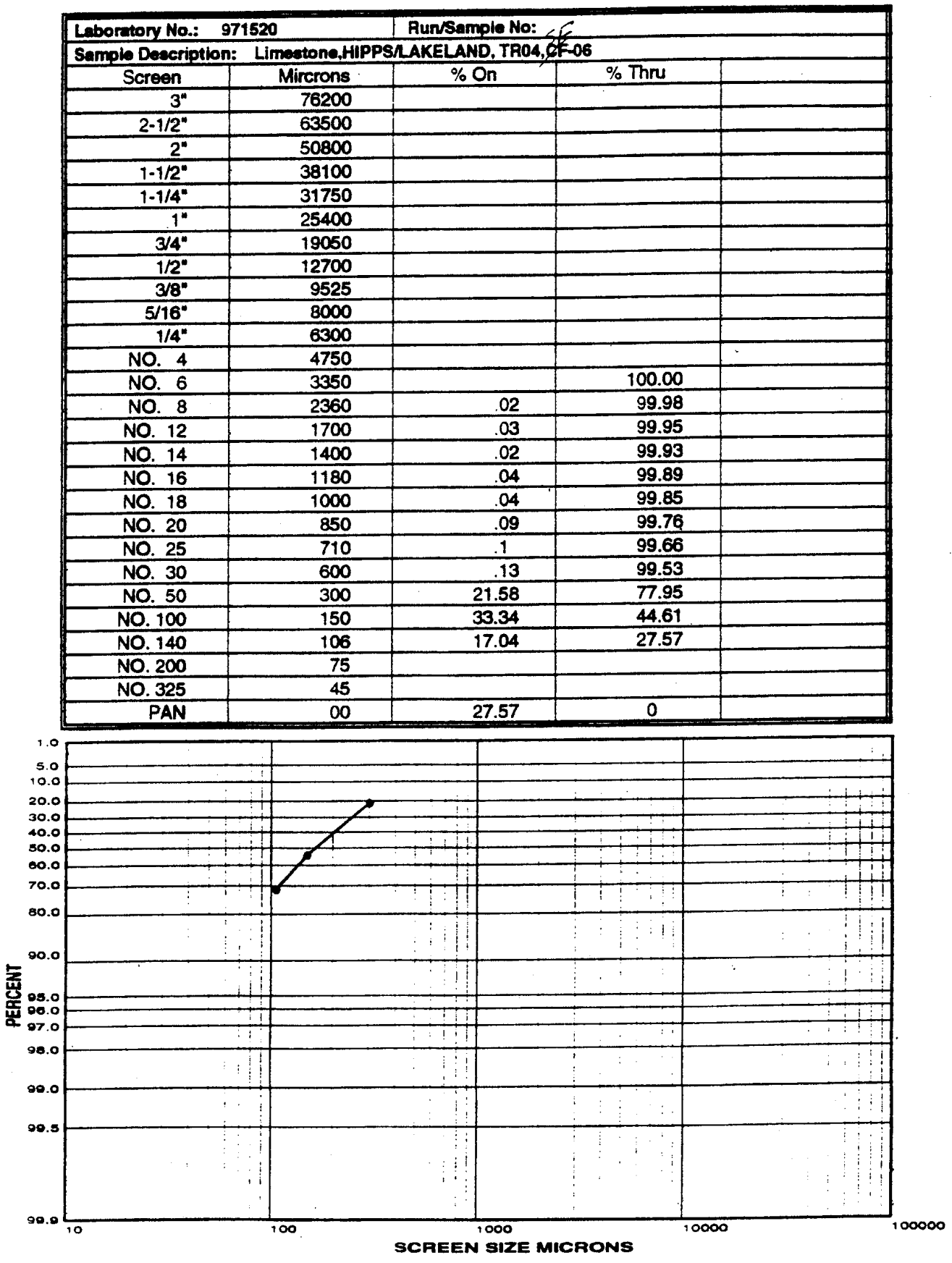




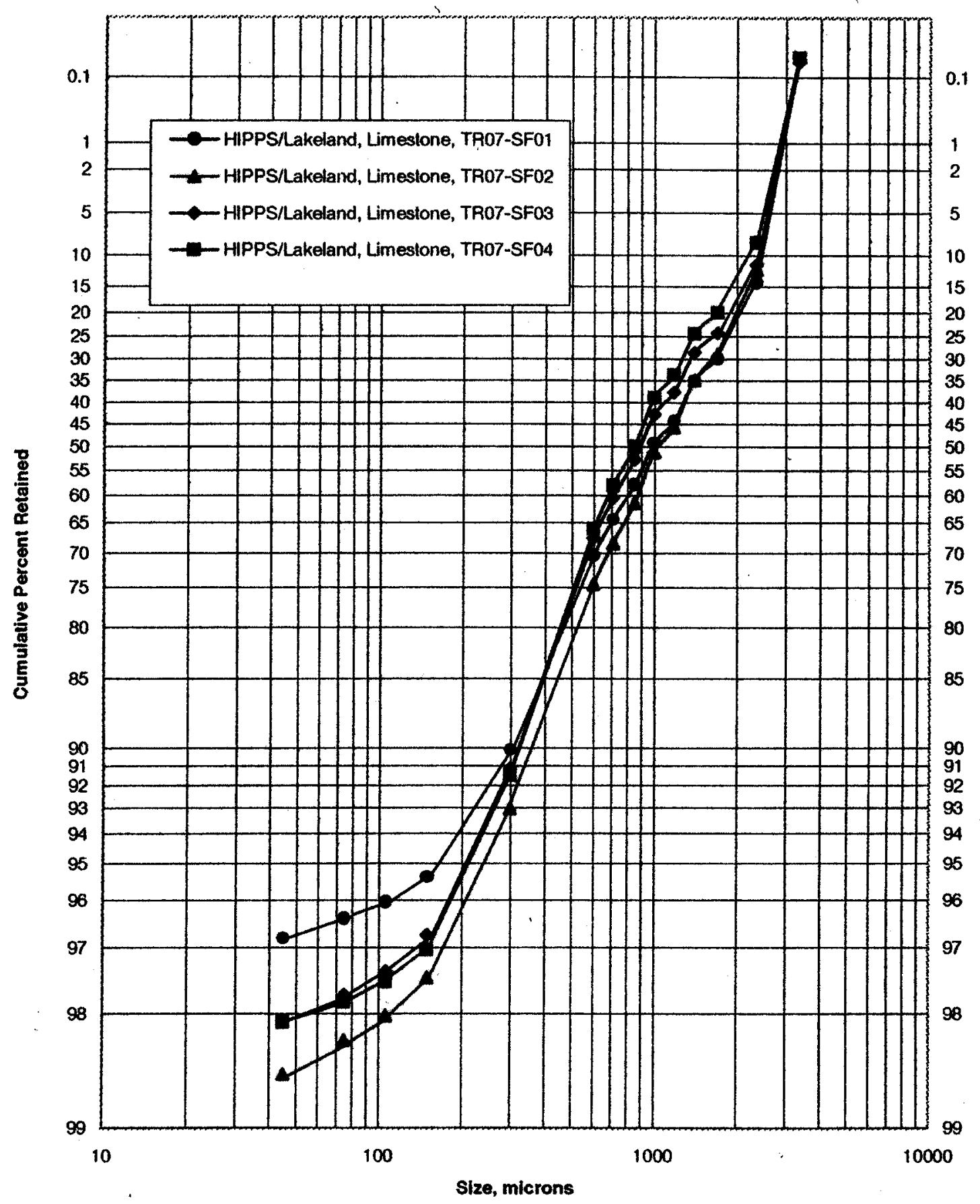

Figure 3.1.1 Size Distribution of Limestone Feed Samples from Test Run TR7 


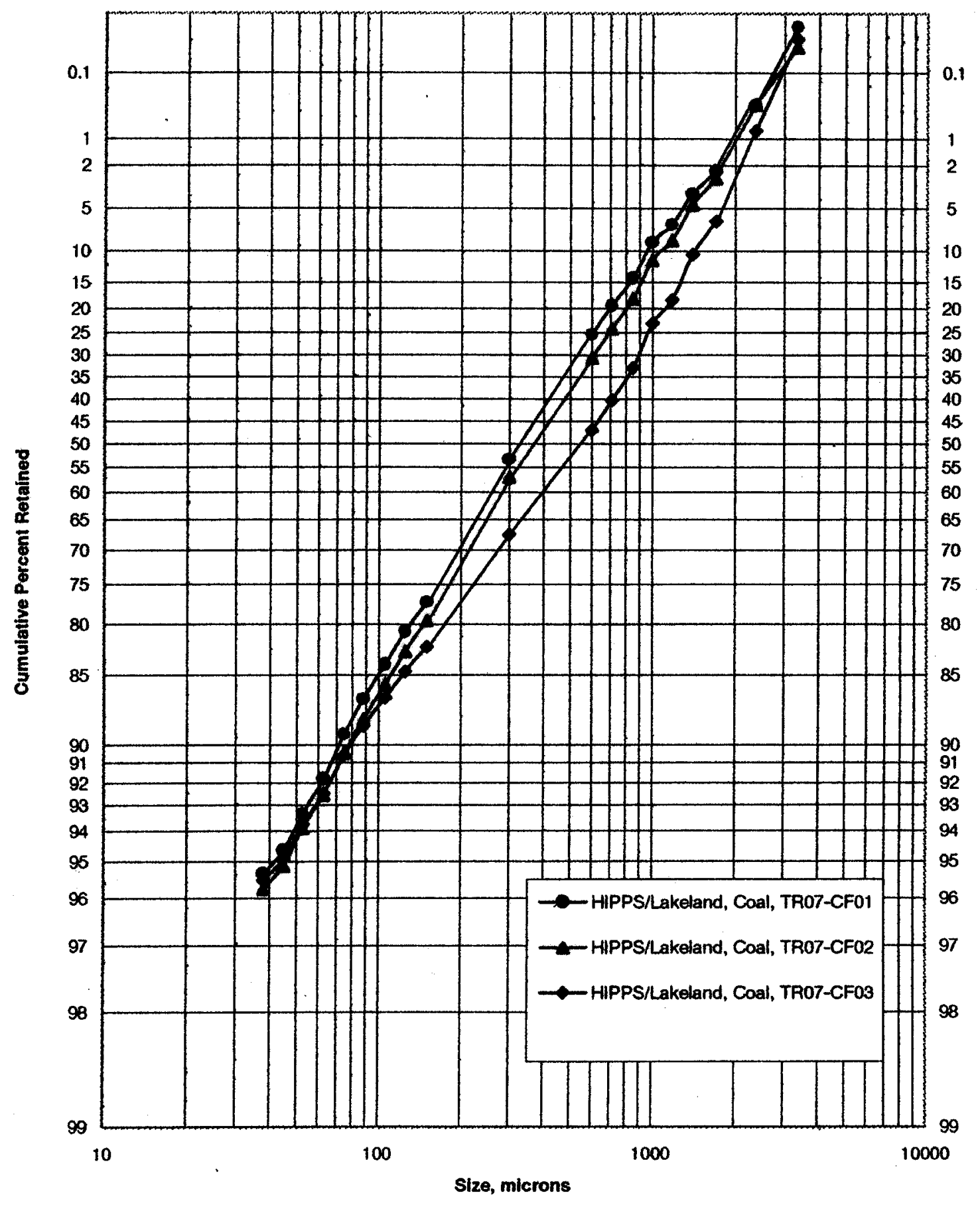

Figure 3.1.2 Size Distribution of Coal Feed Samples from Test Run TR7 


\subsection{Sorbent Feed Size and Bed Agglomeration}

In the first two test runs (TR4 and 5) the Florida limestone was crushed to the fine size distribution $(\mathrm{d} 50 \approx 150 \mu)$ planned for the Lakeland PCFB boiler, the attempt being made to use the same feed size in both the carbonizer and PCFB to minimize feedstock preparation costs. With the carbonizer being a bubbling bed unit, essentially all previous testing had been conducted with a $1 / 8$ " x 0 limestone feed size $(\mathrm{d} 50 \approx 600 \mu)$. In addition, the carbonizer had been operated on a simple, once through basis (particulate elutriated from the bed and captured by a downstream cyclone were not recycled back to the bed). As expected, when the fine feed size was used, most of the sorbent elutriated from the bed and left behind a predominantly char bed. With the bed limestone content reduced, a sulfur capture efficiency of only $93.5 \%$ was achieved with the $1.4 \%$ sulfur Kentucky No 9 coal. Analysis of the minus 300 micron limestone that had been elutriated from the bed revealed little sulfur content. With this size fraction contributing little to the carbonizer sulfur capture efficiency (SCE), a 1/8" x 300 micron feed was tested next by screening out the minus $300 \mu$ material (in the Lakeland plant the minus 300 micron limestone would be saved for use in the $\mathrm{PCFB} \mathrm{SO} 2$ trim system). In the two test runs conducted with the fine sorbent (TR4 and 5) and the first run with the coarse sorbent (TR6), agglomeration was experienced at the bottom of the bed (see Figure 3.2.1). Initially it was thought the low sorbent content of the bed caused by fine sorbent feed was allowing agglomerates to form. Then when agglomeration was experienced with coarse sorbent feed which yielded a sorbent bed, operating conditions were reviewed to seek a cause for the agglomeration.

TI-3021A, located 15-1/2 inches above the top of the carbonizer feed pipe, is the lowest thermocouple in the bed and TI-3016, 12.5 feet above the feed pipe, is the reference bed temperature. Figure 3.2.1 plots these temperatures versus time along with the nitrogen flow (FI-3028) to the drain cooler and the velocity (V) of this nitrogen as it passes through the drain annulus for Test Run TR 6. It is observed that about one hour after the packed bed nitrogen flow is reduced, TI-3021A begins to depart from TI-3016 and about one hour later a temperature excursion/upset occurs. A review of Test Runs TR 4 and 5 revealed a similar relationship, e.g., a reduction in nitrogen flow/velocity is soon followed by excursions in TI-3021 A and a bed upset.

Suspecting a lack of fluidization to be the cause of the agglomeration, it was decided to keep the fluidizing velocity in the drain annulus surrounding the feed pipe at a value of $2 \mathrm{ft} / \mathrm{sec}$ regardless of whether or not cooling flow was needed. Using this higher velocity, TR7 was conducted without experiencing any agglomeration problems and the unit operated successfully until a high baghouse back pressure forced the termination of the run. The first setpoint completed (TR7.1) was performed with $4.1 \%$ sulfur coke at a sorbent-to-coal mass feed ratio of $0.22 \mathrm{lbs}$ per $\mathrm{lb}$ of coal; this yielded a calcium-to-sulfur molar feed ratio of 1.4. When the fuel was switched to $1.4 \%$ sulfur Kentucky No 9 coal, the $0.20 \mathrm{lbs}$ of limestone per $\mathrm{lb}$ of coal feed rate yielded a 3.4 molar feed ratio. Although we had intended to systematically reduce the sorbent-to-coal mass feed ratio to see what minimum level, if any, would cause agglomeration with the $2 \mathrm{ft} / \mathrm{sec}$ annulus velocity and Kentucky No 9 coal, the forced shutdown of the plant prevented us from doing so. In Test Run TR5 the carbonizer operated for 30 hours with fine sorbent and Kentucky No 9 coal before the packed bed nitrogen flow was reduced and agglomeration problems developed. Based on this, it is surmised that the coarse sorbent would yield agglomeration-free operation at a sorbent-to-coal mass feed ratio as low as 0.07 , the value used in TR5. 


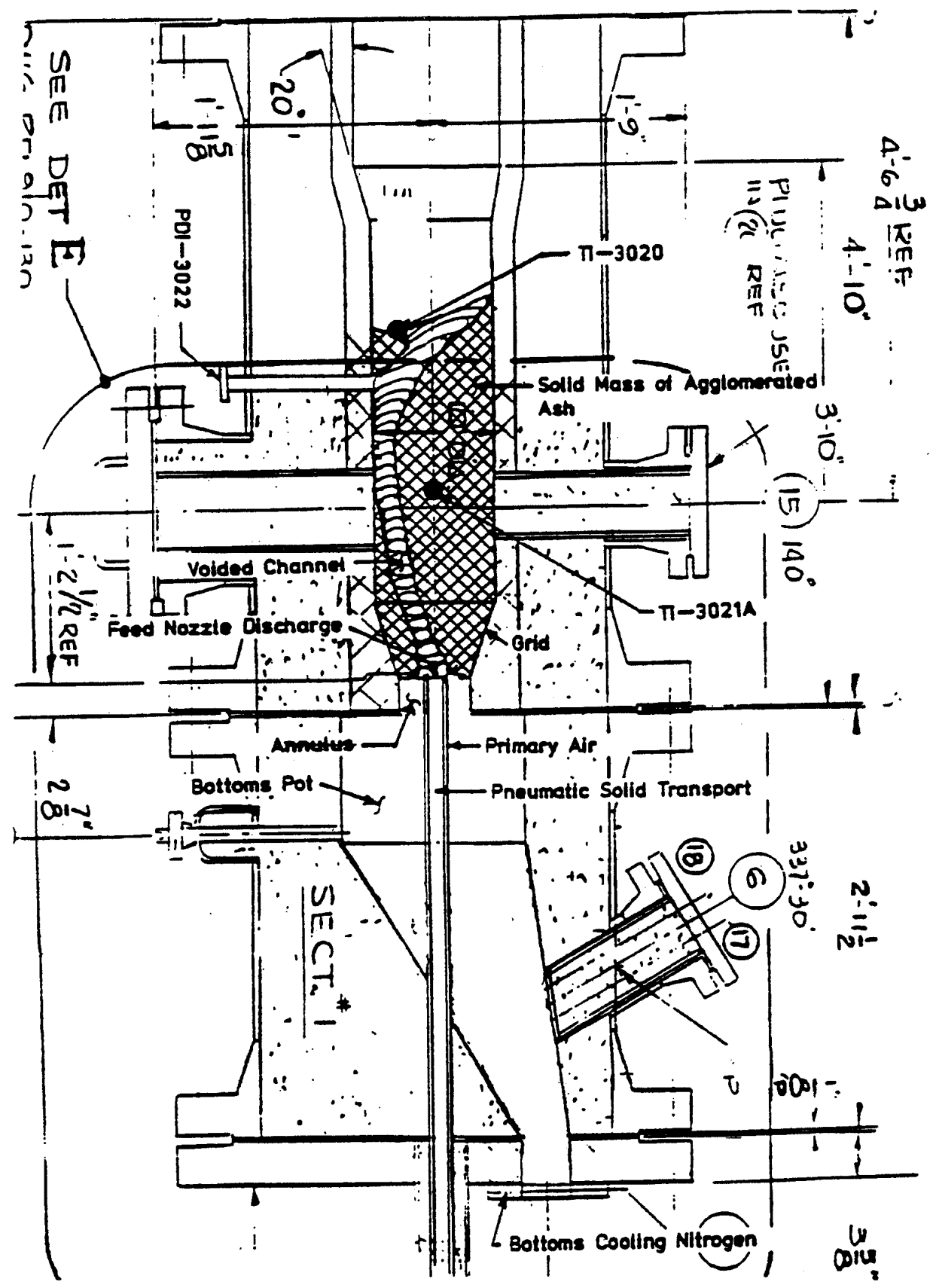

Figure 3.2.1 Agglomeration Experienced in Carbonizer Test Run TR4 


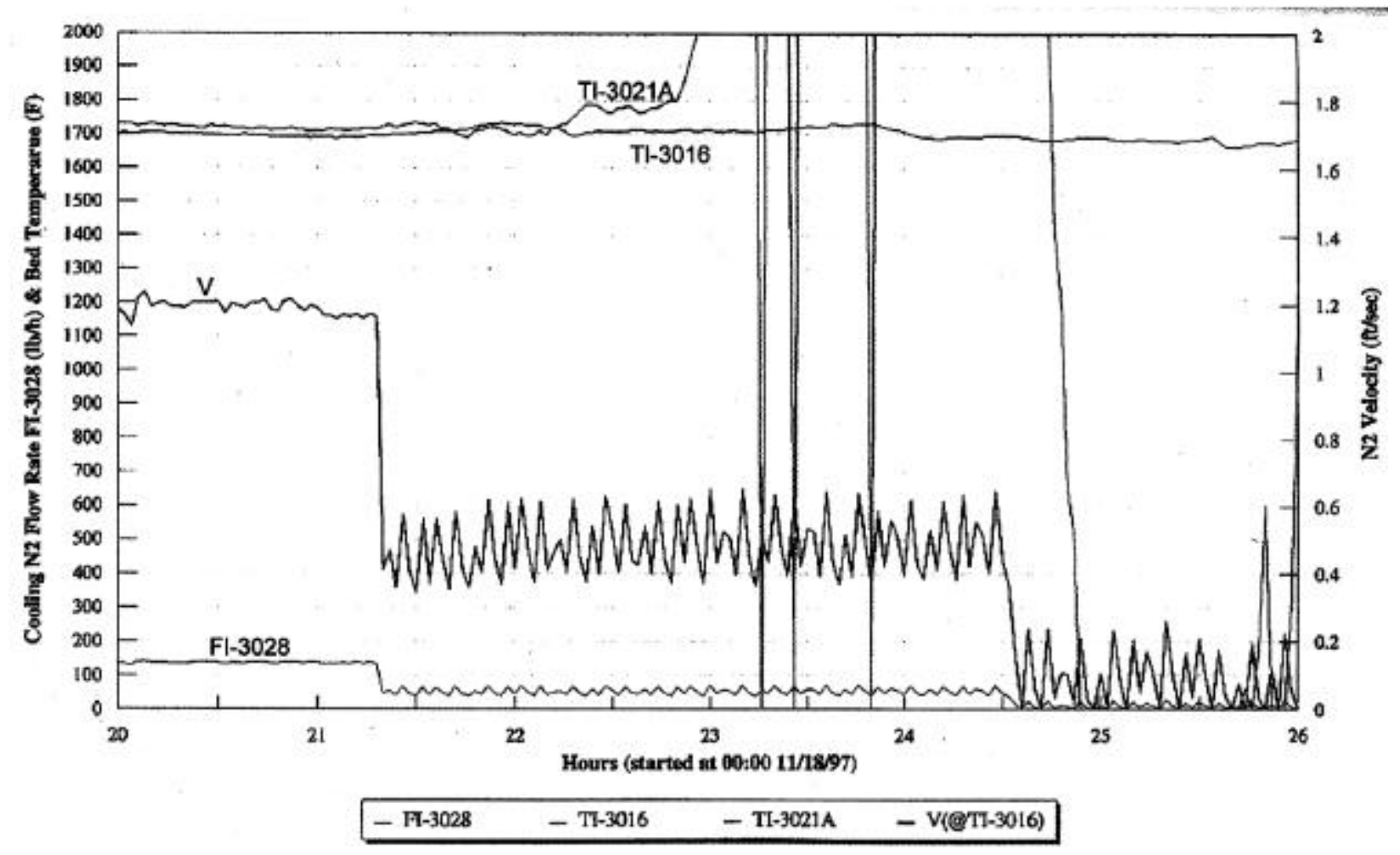

Figure 3.2.2 TR6 Bed Temperatures and Cooler Flows 


\subsection{Overall Performance}

Table 3.3.1 summarizes the pilot plant operating conditions and test results. Carbonizer test pressures, temperatures, and bed heights ranged from 90 to $165 \mathrm{psig}, 1718$ to $1808 \mathrm{EF}$, and 23.5 to 27.7 feet respectively. The syngas produced by the carbonizer was sampled at the outlet of the demister after the gas had been depressured and water spray quenched to approximately $350 \mathrm{EF}$. With the syngas being slightly pressurized at this point, two 3 liter Kevlar bags were easily filled with the gas for analysis in a gas chromatograph (GC) usually within 24 hours of collection. After collection hydrochloric acid $(\mathrm{HCl})$ was injected into one bag to convert the ammonia $\left(\mathrm{NH}_{3}\right)$ in the fuel gas to ammonium chloride $\left(\mathrm{NH}_{4} \mathrm{CL}\right)$ while awaiting analysis. Similarly, sodium hydroxide was injected into the other bag to convert hydrogen sulfide $\left(\mathrm{H}_{2} \mathrm{~S}\right)$ to sodium sulfide or sodium hydrosulfide $\left(\mathrm{Na}_{2} \mathrm{~S} / \mathrm{NaHS}\right)$. During each set point the syngas was sampled at least 5 times yielding 10 bags for analysis. In addition, multiple hydrogen sulfide $\left(\mathrm{H}_{2} \mathrm{~S}\right)$ and ammonia $\left(\mathrm{NH}_{3}\right)$ Drager tube measurements (DT) were made during each set point at the sampling location as a check that equilibrium/steady state conditions had been achieved before the start of and throughout the set point plus allowing a check of the GC measurement; both the GC and Drager tubes were found to be in close agreement. Table 3.3.2 presents the GC analysis on a moisture free basis and includes all nitrogen purges, i.e., bed drain cooler, pressure taps, water spray atomization, etc.

Because of all the nitrogen flows, calculated gas heating values are low and coal syngas values rise to 104 to $118 \mathrm{Btu} / \mathrm{SCF}$ on a purge nitrogen free basis (only air nitrogen included); correcting for the pilot plant high heat loss, they rise to typical, predicted commercial plant values of 126 to $138 \mathrm{Btu} / \mathrm{SCF}$. Corresponding petroleum coke values are less because of the coke's lower volatile content (10.8 vs. $31.4 \%$ ). The carbonizer syngas and the char sorbent residue were separately analyzed to determine the amount of fuel carbon that had been consumed (carbon conversion) in each of the runs, an effort that requires subtraction of sorbent carbon from the total carbon content. The residue streams are identified in Table 3.3.3 as drains from the bottom of the bed (bot) and combined drains, where applicable, from the cyclone and filter as overheads (ovhd).

Since the elutriated fine material/overheads are not reinjected back into the bed, their shorter inbed residence time results in carbon conversion levels (fc) that are much lower than that of the bed bottom drains (note that overheads carbon-to-ash ratios are also higher and closer to that of the fuel fed - C/Ash (fed)). The carbon conversion of the combined overhead and bottom streams are reported as fc (solid). Despite numerous analyses, we have always observed that the carbon conversion calculated from an analysis of the solids residue is higher than that calculated from a syngas analysis. The disparity decreases with increasing temperature, and we suspect that higher hydrocarbons are being missed in the gas bomb gas chromatograph process. Consistent with this previous experience, Table 3.3.3 syngas analyses yield lower carbon conversion levels than solid residue analyses and for conservatism we continue to report and base our predictive correlations on the lower/former as varying from 32.5 to $41.4 \%$. 
Table 3.3.1 Lakeland Carbonizer Test Results

\begin{tabular}{|c|c|c|c|c|c|c|}
\hline Test Run & \multicolumn{2}{|c|}{4} & \multirow{2}{*}{$\begin{array}{c}5 \\
5.1\end{array}$} & \multirow{2}{*}{$\begin{array}{c}6 \\
6.1\end{array}$} & \multicolumn{2}{|c|}{7} \\
\hline Set Point & 4.1 & 4.2 & & & 7.1 & 7.2 \\
\hline Sorbent Size & fine & fine & fine & coarse & coarse & coarse \\
\hline Bed Temperature, ${ }^{\circ} \mathrm{F}^{*}$ & 1761 & 1808 & 1756 & 1695 & 1752 & 1718 \\
\hline Freeboard Pressure, psig & 90 & 105 & 122 & 146 & 160 & 165 \\
\hline Bed Height, $\mathrm{ft}$ & 27.3 & 27.4 & 27.7 & 27.5 & 23.5 & 26.0 \\
\hline Ky No 9 Coal Flow Rate, lb/h & 289 & 289 & 380 & 373 & $281^{+}$ & 304 \\
\hline Air Flow Rate, lb/h & 582 & 672 & 733 & 713 & 791 & 754 \\
\hline Limestone Flow Rate, lb/h & 20 & 23 & 29 & 64 & 63 & 60 \\
\hline $\mathrm{Ca} / \mathrm{S}$ Molar Feed Ratio & 1.50 & 1.70 & 1.58 & 3.57 & 1.38 & 3.36 \\
\hline Set Point Duration, hrs. & 10 & 19 & 39 & 6 & 3 & 6 \\
\hline Syngas Flow Rate**, lb/h & 965 & 1082 & 1213 & 1460 & 1641 & 1597 \\
\hline Syngas HHV ${ }^{\Delta}$, Btu/SCF & 138 & 126 & 133 & 133 & 111 & 132 \\
\hline Carbon Conversion $^{\mathrm{G}}, \%$ & 36.2 & 40.8 & 32.9 & 32.5 & 35.6 & 41.4 \\
\hline Fuel Sulfur Released, \% & 58.4 & 74.0 & 65.0 & 58.5 & 79.5 & 79.0 \\
\hline Sulfur Capture Eff., \% & 93.7 & 93.6 & 93.6 & 94.5 & 98.7 & 95.1 \\
\hline Fuel Nitrogen Released, \% & 53.6 & 51.2 & 55.1 & 54.6 & 33.3 & 57.0 \\
\hline Rel'd Nitrogen to $\mathrm{NH}_{3}, \%$ & 8.0 & 7.2 & 6.7 & 16.7 & 17.7 & 22.5 \\
\hline Nitrogen flow, lb/h & 303 & 310 & 392 & 371 & 528 & 519 \\
\hline Bed Drain, lb/h & 15 & 15 & 21 & 36 & 211 & 103 \\
\hline Overhead Drain, lb/h & 149 & 149 & 182 & 183 & 77 & 101 \\
\hline
\end{tabular}

\footnotetext{
*at $12.5 \mathrm{ft}$ height

${ }^{+}$pet coke

${ }^{\Delta} \mathrm{N}_{2}$ and heat loss free

$\mathrm{G}_{\text {gas analysis }}$

**includes all $\mathrm{N}_{2}$ flows and water spray
} 
Table 3.3.2 Carbonizer Syngas Composition*

\begin{tabular}{|l|c|c|c|c|c|c|}
\hline Test Run & \multicolumn{2}{|c|}{ TR4 } & TR5 & TR6 & \multicolumn{3}{c|}{ TR7 } \\
\hline Set Point & TR4.1 & TR4.2 & TR5.1 & TR6.1 & TR7.1 & TR7.2 \\
\hline H2, \%v & 7.49 & 7.34 & 7.18 & 5.43 & 4.69 & 5.50 \\
\hline CO, \%v & 9.06 & 10.89 & 8.81 & 7.77 & 6.43 & 7.39 \\
\hline CH4, \%v & 1.82 & 1.05 & 2.05 & 1.78 & 0.27 & 1.29 \\
\hline C'2, \%v & 0.02 & 0.00 & 0.01 & 0.01 & 0.00 & 0.00 \\
\hline CO2, \%v & 5.78 & 5.35 & 6.09 & 5.67 & 5.50 & 4.99 \\
\hline N2, \%v & 76.28 & 75.81 & 76.22 & 79.48 & 83.14 & 79.42 \\
\hline Ar, \%v & 0.48 & 0.51 & 0.51 & 0.46 & 0.42 & 0.42 \\
\hline gasC/Ar & 34.79 & 33.90 & 33.27 & 33.13 & 29.05 & 32.55 \\
\hline HHV, Btu/SCF & 76 & 73 & 76 & 64 & 41 & 57 \\
\hline HHV (N2 free), Btu/SCF & 118 & 109 & 114 & 108 & 78 & 104 \\
\hline HHV (commercial), Btu/SCF & 138 & 126 & 133 & 133 & 111 & 132 \\
\hline
\end{tabular}

* moisture free basis but including all cooling, purge, and atomizing nitrogen flows.

Table 3.3.3 Carbon Content of Carbonizer Streams

\begin{tabular}{|l|c|c|c|c|c|c|}
\hline Test Run & \multicolumn{2}{|c|}{ TR4 } & TR5 & TR6 & \multicolumn{2}{c|}{ TR7 } \\
\hline Set Point & TR4.1 & TR4.2 & TR5.1 & TR6.1 & TR7.1 & TR7.2 \\
\hline C Fuel, \% & 74.87 & 74.87 & 75.58 & 75.49 & 88.90 & 75.49 \\
\hline C/Ash (fed), \% & 6.47 & 6.47 & 7.08 & 7.21 & 80.09 & 7.21 \\
\hline C/Ash (ovhd), \% & 4.23 & 3.28 & 4.71 & 4.44 & 56.97 & 4.86 \\
\hline C/Ash (bot), \% & 2.17 & NA & 2.13 & 1.64 & 12.29 & 2.40 \\
\hline gas C/Ar, \% & 34.79 & 33.90 & 33.27 & 33.13 & 29.05 & 32.55 \\
\hline fuel C/Ar, \% & 96.00 & 83.14 & 101.06 & 101.85 & 81.54 & 78.57 \\
\hline fc, \% (gas)* & 36.24 & 40.77 & 32.92 & 32.53 & 35.63 & 41.43 \\
\hline fc, \% (ovhd) & 34.51 & 49.28 & 33.57 & 38.42 & 28.87 & 32.56 \\
\hline fc, \% (bot) & 66.46 & NA & 69.94 & 77.25 & 84.65 & 66.69 \\
\hline fc, \% (solid) & 37.43 & NA & 37.39 & 42.49 & 69.88 & 50.33 \\
\hline *Carbonate C included & & & & & & \\
\hline
\end{tabular}




\subsection{Syngas Ammonia and $\mathrm{H}_{2} \underline{\underline{S} \text { Levels }}$}

Syngas $\mathrm{NH}_{3}$ and $\mathrm{H}_{2} \mathrm{~S}$ Drager tube measurements were, for the most part, in close agreement with the GC results. Analysis of the syngas GC data and residue compositions (see Table 3.4.1) indicate that the Lakeland coal nitrogen $(\mathrm{N})$ release rates ranged from 51.2 to $57.0 \%$ and that 6.7 to $22.5 \%$ of the released nitrogen was converted to ammonia. The conversion of released nitrogen to ammonia varies with the feedstock and decreases with increasing temperature. Despite this, we (as well as other investigators) have been unable to develop a correlation for predicting this conversion. In previous tests, our conversions have in some instances approached $100 \%$ with an overall average of about $60 \%$; this range in conversion is similar to data collected in the Otaniemi Finland 6-inch ID bubbling bed gasifier with operating conditions and results shown in Table 3.4.2 and Figure 3.4.1 [3-1]*. When reviewing Figure 3.4.1 note that the Otaniemi conversions are based on the fuel nitrogen fed rather than fuel nitrogen actually released; if the former was used, conversions will be higher. We note that TR6 and TR7 nitrogen to ammonia conversion levels and limestone feed rates are much higher than TR4 and TR5.

Table 3.4.1 Syngas Ammonia Analyses of GC Data

\begin{tabular}{|l|c|c|c|c|c|c|}
\hline Test Run & \multicolumn{2}{|c|}{ TR4 } & TR5 & TR6 & \multicolumn{2}{c|}{ TR7 } \\
\hline Set Point & TR4.1 & TR4.2 & TR5.1 & TR6.1 & TR7.1 & TR7.2 \\
\hline N Fuel, \% & 1.52 & 1.52 & 1.53 & 1.57 & 1.46 & 1.57 \\
\hline N/C (fed), \% & 0.0203 & 0.0203 & 0.0202 & 0.0208 & 0.0164 & 0.0208 \\
\hline N/C (ovhd), \% & 0.0167 & 0.0155 & 0.0167 & 0.0174 & 0.0160 & 0.0194 \\
\hline N/C (bot), \% & 0.0132 & 0.0132 & 0.0136 & 0.0119 & 0.0127 & 0.0150 \\
\hline Average NH3, ppm & 350 & 267 & 314 & 650 & 283 & 713 \\
\hline NH3/N fuel, \% & 4.3 & 3.7 & 3.7 & 9.1 & 5.9 & 12.8 \\
\hline NOx Stack, lb/h & 0.19 & 0.34 & 0.85 & 0.97 & 0.52 & 1.02 \\
\hline NOx/N Fuel, \% & 2.0 & 3.7 & 5.8 & 9.6 & 5.6 & 10.1 \\
\hline N Released, \% & 53.6 & 51.2 & 55.1 & 54.6 & 33.3 & 57.0 \\
\hline NH3/N Released, \% & 8.0 & 7.2 & 6.7 & 16.7 & 17.7 & 22.5 \\
\hline
\end{tabular}

* Numbers in brackets designate references given in Section 6

In TR4 the unit was started with a sand bed and $\mathrm{H}_{2} \mathrm{~S}$ Drager tube values start high as shown in Figure 3.4.2 and decrease with time to a steady state value that reflects the establishment of a char-sorbent bed. In all other test runs the unit was started with a limestone bed and $\mathrm{H}_{2} \mathrm{~S}$ levels start low and increase with time to a steady state value again reflecting establishment of a charsorbent bed (see Figure 3.4.3). In TR4 and 5 a pulverized zinc oxide ( $\mathrm{ZnO}$ ) water slurry was sprayed horizontally into the top of the carbonizer directly opposite the syngas outlet pipe. These spray injections were conducted to demonstrate that $\mathrm{ZnO}$ could be used as a second sulfur 
capturing/polishing step to increase the carbonizer overall sulfur capture efficiency. The Figure 3.4.2 and 3.4.3 Drager tube data confirms this and results are discussed in Section 3.6.

Table 3.4.2 Typical $\mathrm{NH}_{3}$ and HCN Contents of the Product Gas w/Different Feedstocks

\begin{tabular}{|c|c|c|c|c|c|c|c|}
\hline & $\begin{array}{c}\text { Pine } \\
\text { Sawdust }\end{array}$ & Peat A & Peat B & $\begin{array}{c}\text { Brown } \\
\text { Coal }\end{array}$ & $\begin{array}{l}\text { Iowa } \\
\text { Coal }\end{array}$ & $\begin{array}{c}\text { Polish } \\
\text { Coal }\end{array}$ & $\begin{array}{c}\text { Illinois } \\
\text { No.6 Coal }\end{array}$ \\
\hline $\begin{array}{l}\text { Nitrogen } \\
\text { content in the } \\
\text { fuel, wt } \%\end{array}$ & $0.1-0.15$ & $0.7-0.8$ & $1.7-2.0$ & 0.8 & $0.6-0.8$ & $1.2-1.4$ & $1.2-1.3$ \\
\hline Pressure, $\mathrm{MPa}$ & 0.4 & $0.4-0.8$ & $0.4-1.0$ & $0.5-0.7$ & $0.5-0.8$ & 0.5 & 0.5 \\
\hline $\begin{array}{l}\text { Freeboard } \\
\text { temp., EC }\end{array}$ & $900-1000$ & $855-920$ & $800-940$ & $860-940$ & 920 & $940-1000$ & $950-970$ \\
\hline NH3, ppm-v & $300-950$ & $4200-4900$ & $5800-9200$ & $2000-2600$ & $2400-2500$ & $1600-2600$ & $950-1300$ \\
\hline $\mathrm{HCN}, \mathrm{ppm-v}$ & $10-30$ & $60-120$ & $40-300$ & $50-90$ & $12-14$ & $20-160$ & $10-30$ \\
\hline
\end{tabular}




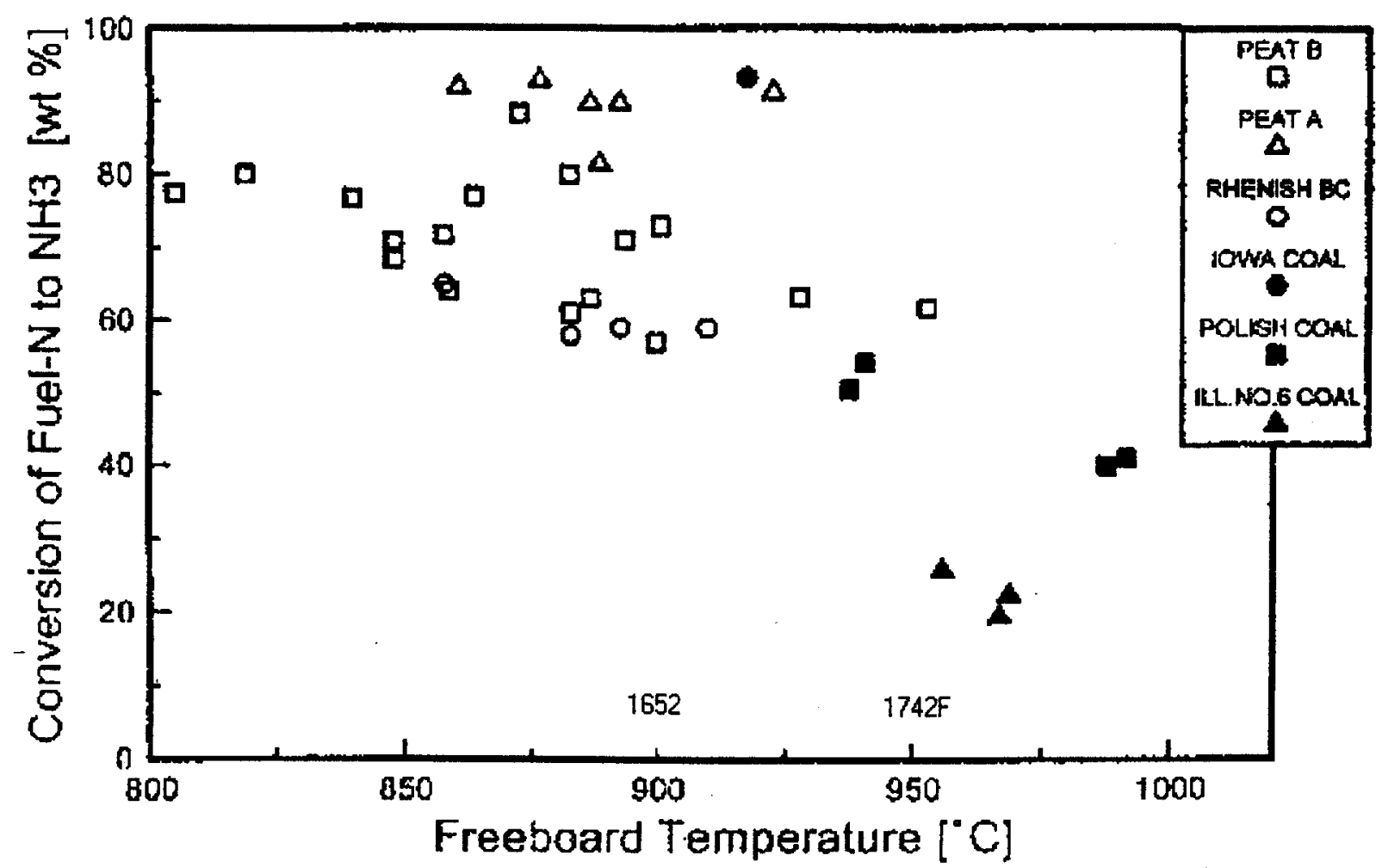

The conversion of fuel nitrogen to $\mathrm{NH}_{3}$ in test runs with different feedstocks

Figure 3.4.1 $\mathrm{NH}_{3}$ Formation Data from Otaniemi Test Facility 


\section{Lakeland Test Run TR04 H2S Sampling Results (fine limestone)}

(Total 73 H2S Drager tube samples were taken. Total avg. H2S: 102 ppm)

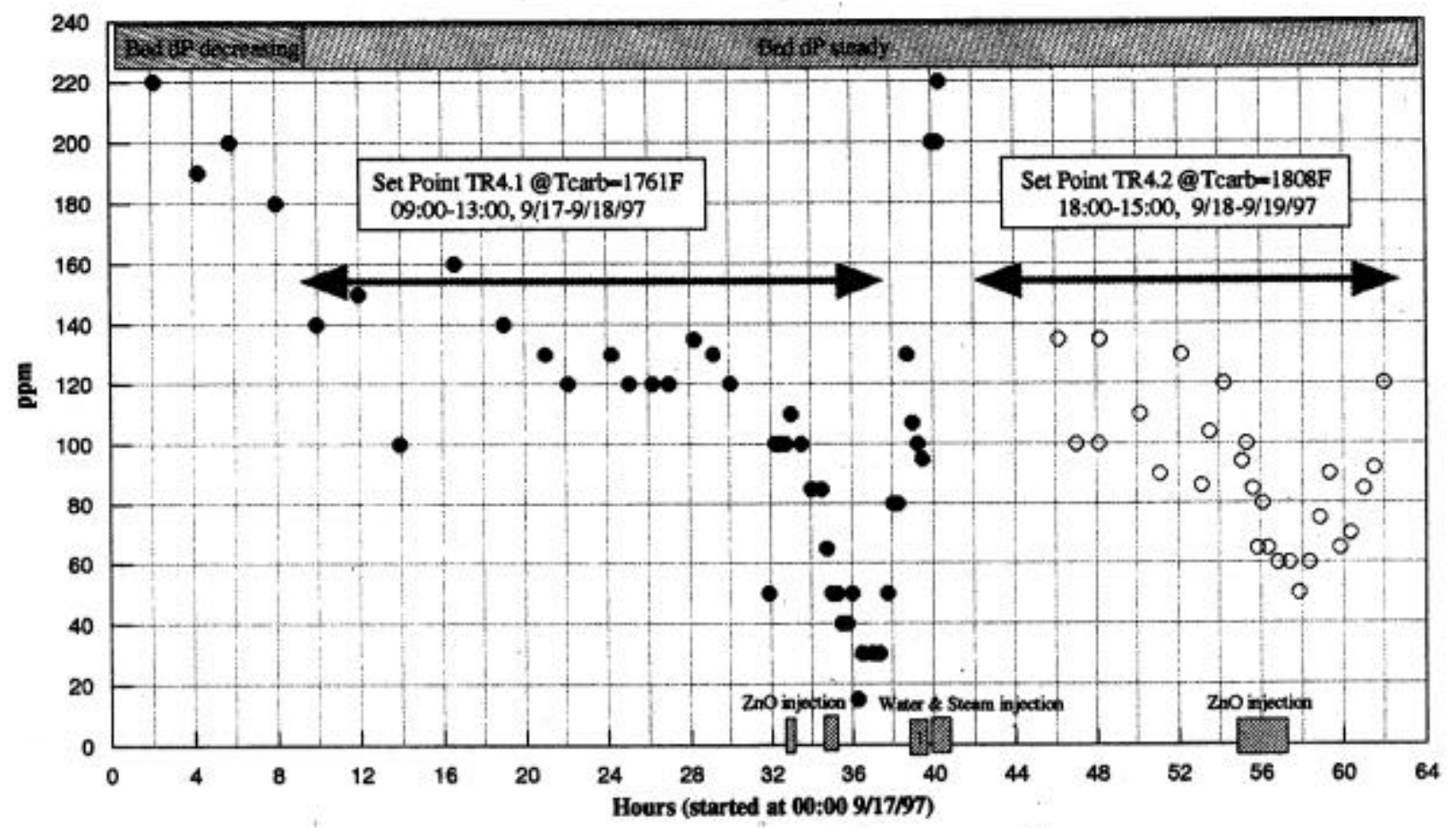

- H2S (by Drager tubes) o H2S (by Drager tubes)

Figure 3.4.2 Test Run TR4 H2S Drager Tube Readings 


\section{Lakeland Test Run TR05 H2S Sampling Results (fine limestone)}

(Total 77 H2S Drager tube samples were taken, total avg. H2S: 107 ppm)

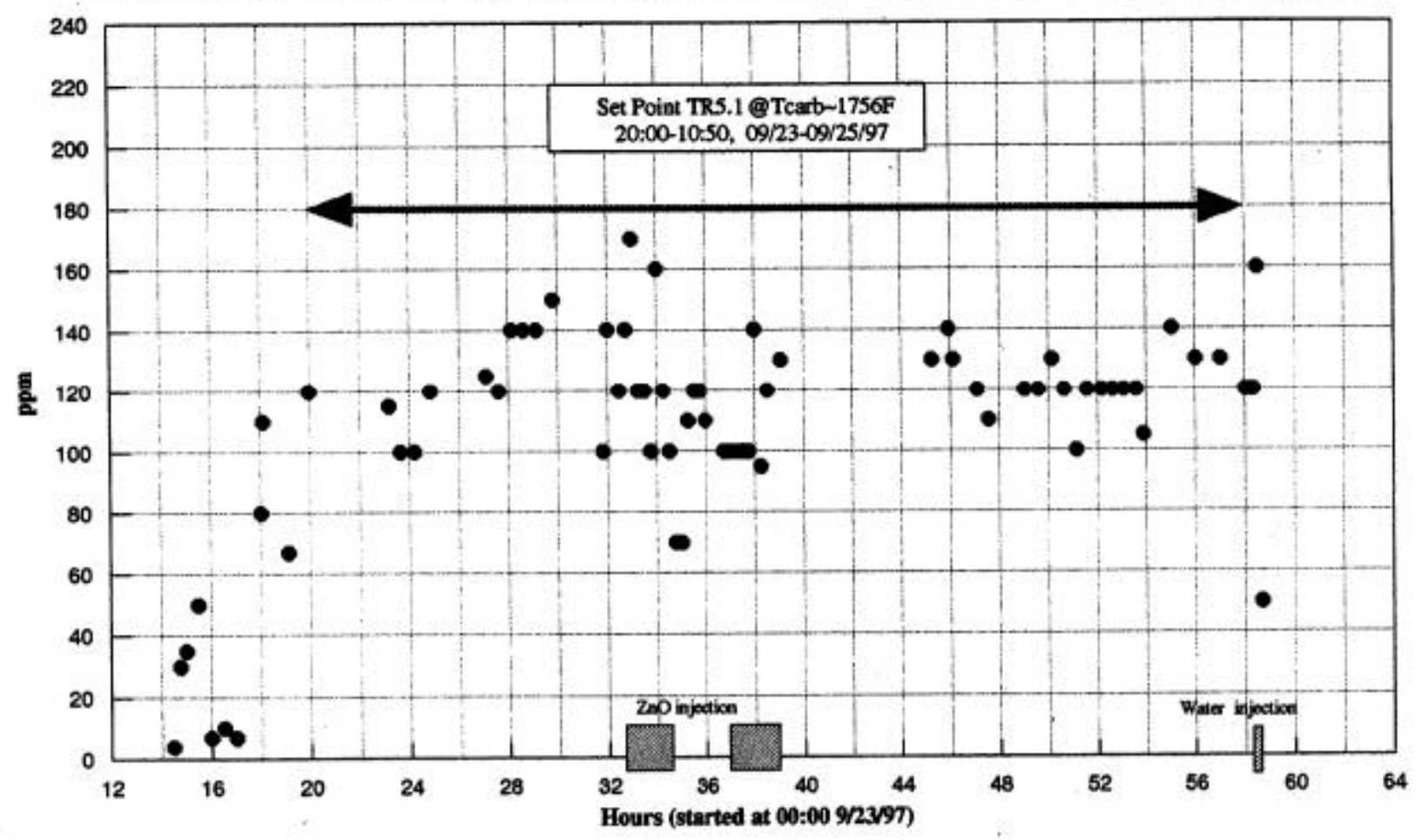

- H2S (by Drager Tubes)

Figure 3.4.3 Test Run TR5 H2S Drager Tube Readings 
By analysis of the syngas and measurement of the syngas flow rate via the choked orifice the amount of hydrogen sulfide/sulfur escaping to the stack was determined. By forming the ratio of escaping sulfur to released sulfur and subtracting it from one, the carbonizer sulfur capture efficiencies (SCE) were determined in Table 3.4.3. Set points 4.1, 4.2, and 5.1, which were conducted with fine limestones, evidenced an SCE of approximately 93.6\%. Set point 6.1 was conducted with coarse (1/8" x 0$)$ limestone at a higher calcium to sulfur molar feed ratio (3.6) and evidenced an SCE of 94.5\%. In Set Points 7.1 and 7.2 a 1/8" x 300 micron limestone feed was used to further increase the sorbent content of the bed and the SCE increased to $95.1 \%$ with the $1.4 \%$ sulfur coal. When $3.9 \%$ sulfur coke was used in Set Point 7.1, the SCE increased to $98.7 \%$.

Table 3.4.3 Carbonizer Sulfur Capture Efficiency

\begin{tabular}{|l|c|c|c|c|c|c|}
\hline Test Run & \multicolumn{2}{|c|}{ TR4 } & TR5 & \multicolumn{2}{c|}{ TR6 } & \multicolumn{2}{c|}{ TR7 } \\
\hline Set Point & TR4.1 & TR4.2 & TR5.1 & TR6.1 & TR7.1 & TR7.2 \\
\hline S Fuel, \% & 1.43 & 1.43 & 1.43 & 1.43 & 4.05 & 1.44 \\
\hline S/C (fed) & 0.019 & 0.019 & 0.019 & 0.019 & 0.046 & 0.019 \\
\hline S/C (ovhd) & 0.013 & 0.011 & 0.014 & 0.014 & 0.022 & 0.011 \\
\hline S/C (bot) & 0.012 & 0.012 & 0.008 & 0.031 & 0.018 & 0.013 \\
\hline H2S, ppm (DT) & 130 & 111 & 118 & 98 & 60 & 86 \\
\hline H2S, ppm (GC) & 115 & 100 & 113 & 114 & 36 & 87 \\
\hline H2S/S fuel, \% & 3.67 & 3.51 & 3.18 & 3.24 & 1.04 & 3.79 \\
\hline SO2 Stack, lb/h & 0.42 & 0.37 & 0.59 & 0.38 & 0.26 & 0.34 \\
\hline SO2/S Fuel, \% & 5.16 & 4.54 & 5.51 & 3.62 & 1.16 & 3.94 \\
\hline S Released, \% & 58.40 & 74.00 & 65.00 & 58.50 & 79.50 & 79.00 \\
\hline Captured/Released, \% & 93.72 & 93.58 & 93.58 & 94.46 & 98.69 & 95.06 \\
\hline
\end{tabular}




\subsection{Bed Composition}

Except during startup, the carbonizer bed is a mixture of char and limestone. Since the char is much lighter than the limestone, the char tends to rise to the upper part of the bed and represents more than half of the material elutriated from the unit. Conversely, the limestone being heavier tends to sink to the lower part of the bed and represents most of the material drained from the bottom of the bed. At the end of Set Point 7.2, which was conducted with coarse $(1 / 8$ " x 300 micron) limestone, the bed was emptied in equal volume batches via the bottom drain. The char content of each batch was measured and Figure 3.5.1 shows that the char content varied linearly with height ranging from about $35 \%$ at the bottom to almost $100 \%$ at the top of the bed. The carbon content of the char was also measured and Figure 3.5.2 shows a linear variation in carbon conversion ranging from $80 \%$ at the bottom, where material is exposed to the air jet, to about $40 \%$ at the top of the bed.

From Figure 3.5.1 it is seen that the carbonizer bed was predominantly char with the latter tending to the top of the bed. This high char content, and conversely low limestone content, bed was the result of operating with the bed overflow drain nozzle blanked off. The latter had been disconnected as a requirement of another test program that utilized pulverized coal (the four Lakeland runs were squeezed in between these other tests). If the overflow drain had been operational, the bed would have had a markedly higher sorbent content and probably would also have exhibited a higher level of sulfur capture. 


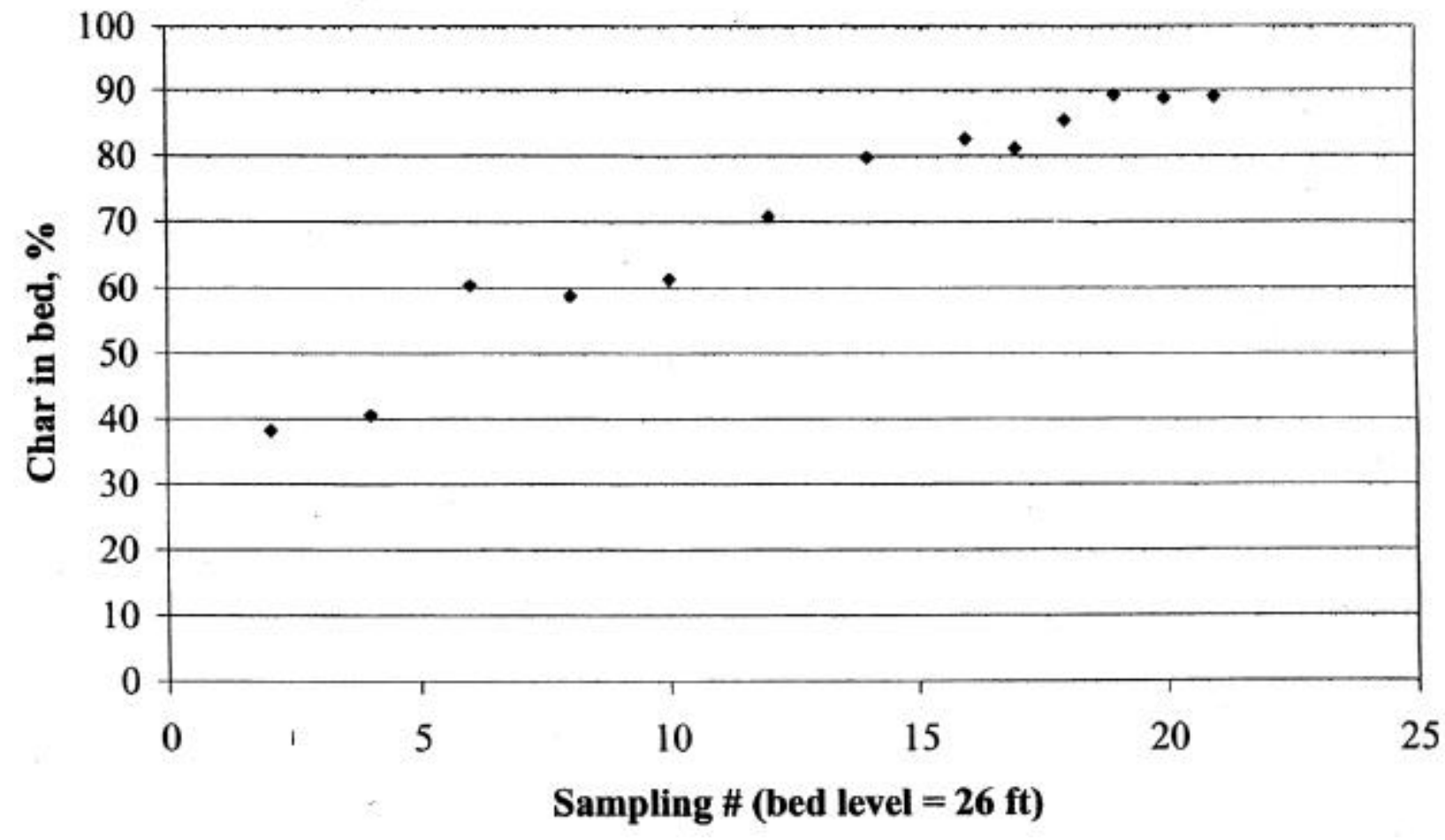

Figure 3.5.1 TR7.2 Bed Char Content via Post Run Inspection 


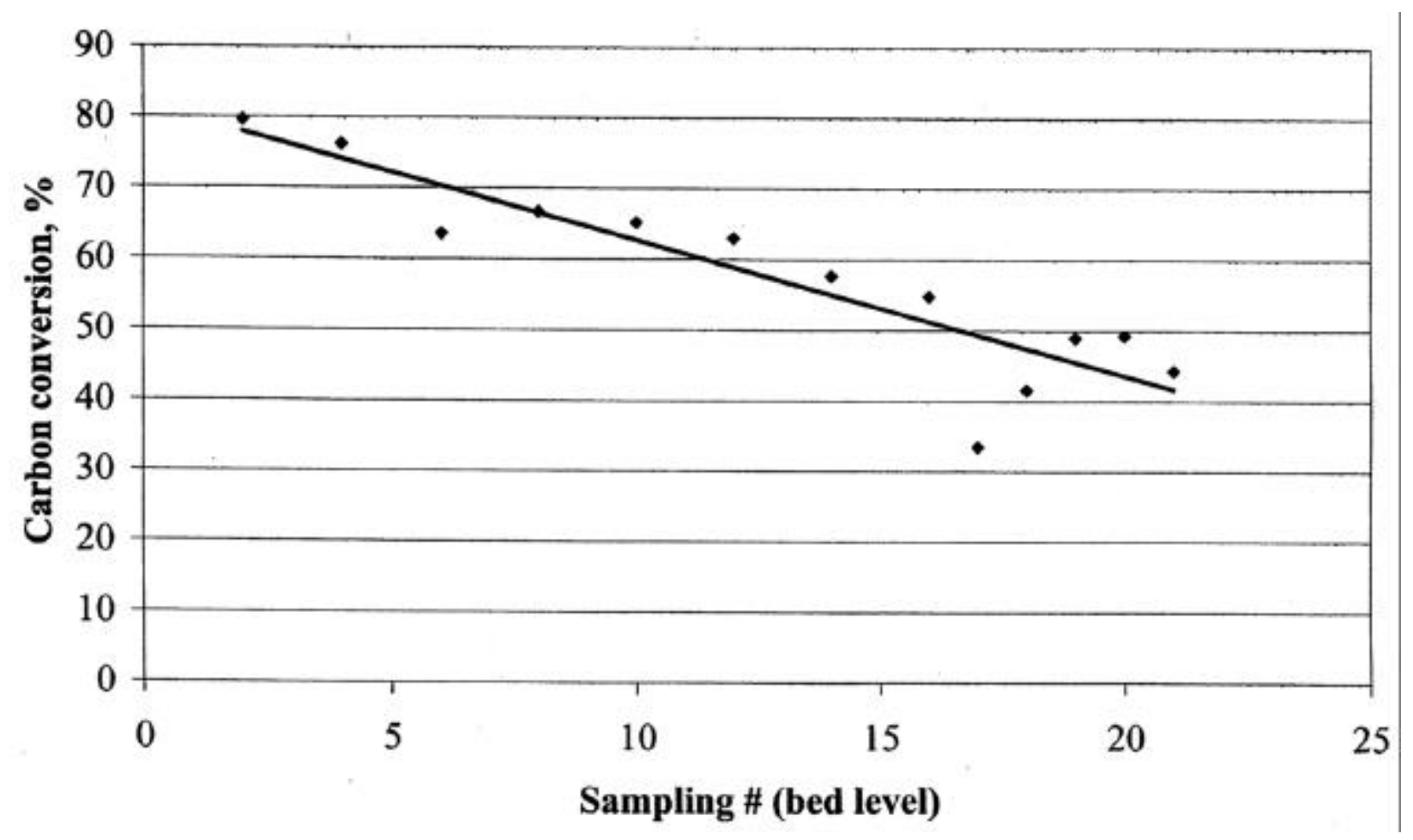

Figure 3.5.2 TR7.2 Char Carbon Content via Post Run Inspection 
Zinc oxide has a higher affinity for capturing sulfur from gases containing hydrogen sulfide than either calcium oxide or calcium carbonate. To increase the carbonizer sulfur capture efficiency to greater than $95 \%$ when partially gasifying low sulfur coals with a limestone bed and/or increase the sulfur capture efficiency of an under performing unit, pulverized zinc oxide can be injected into the carbonizer syngas upstream of the ceramic candle filter. A series of tests involving zinc oxide injection were conducted in the 12-inch diameter Livingston pilot plant carbonizer to determine what improvement in sulfur capture efficiency might be achieved.

The pulverized zinc oxide was injected as 5 to $15 \%$ by weight water slurry into the top of the carbonizer via a horizontal, nitrogen atomized nozzle inserted through a cleanout plug provided opposite the syngas outlet (see Figure 3.6.1). The injection nozzle was a Delavan Spray Technologies Swirl-Air Atomizing Nozzle P/N 32740-13 with a 32742 adapter. Although the nominal rating of the nozzle is $1.0 \mathrm{gpm}$ and the flow rate requirements of the testing were only in the range of 1 to $4 \mathrm{gph}$, the vendor indicated performance would be satisfactory. Since the major source of energy for liquid atomization in this gas-assisted nozzle is the pneumatic energy of the gas, the liquid flow rate has only a minor effect on the nozzle overall pressure drop. Bench testing of the nozzle at atmospheric pressure and test run flow rates of liquid confirmed this.

At the nominal nozzle capacity of 1.0 gpm the nozzle effects a spray angle of 50E which rapidly collapses into a straight columnar type pattern within the first couple feet from the nozzle discharge. The maximum pattern diameter at an 80 psig atomizing gas pressure drop is predicted by the vendor to be 18 inches in ambient air conditions. At the low flow rate at which this nozzle operated in the test run, the vendor predicted a maximum pattern diameter of under 12 inches in ambient air conditions. The vendor also predicted that in the $1700 \mathrm{EF}$ environment of the carbonizer the liquid should evaporate almost immediately at the nozzle discharge. The vendor's predicted Sauter mean droplet diameter for the carbonizer conditions was 27 microns.

The piping run length from the carbonizer syngas outlet nozzle to the candle filter was about 30 feet long (there was no cyclone) and the syngas pipe velocity was about $60 \mathrm{ft} / \mathrm{sec}$. The residence of the zinc oxide in the overhead system is of the order of one second or less. Therefore, the major dwell time of the zinc oxide occurred on the filter. 


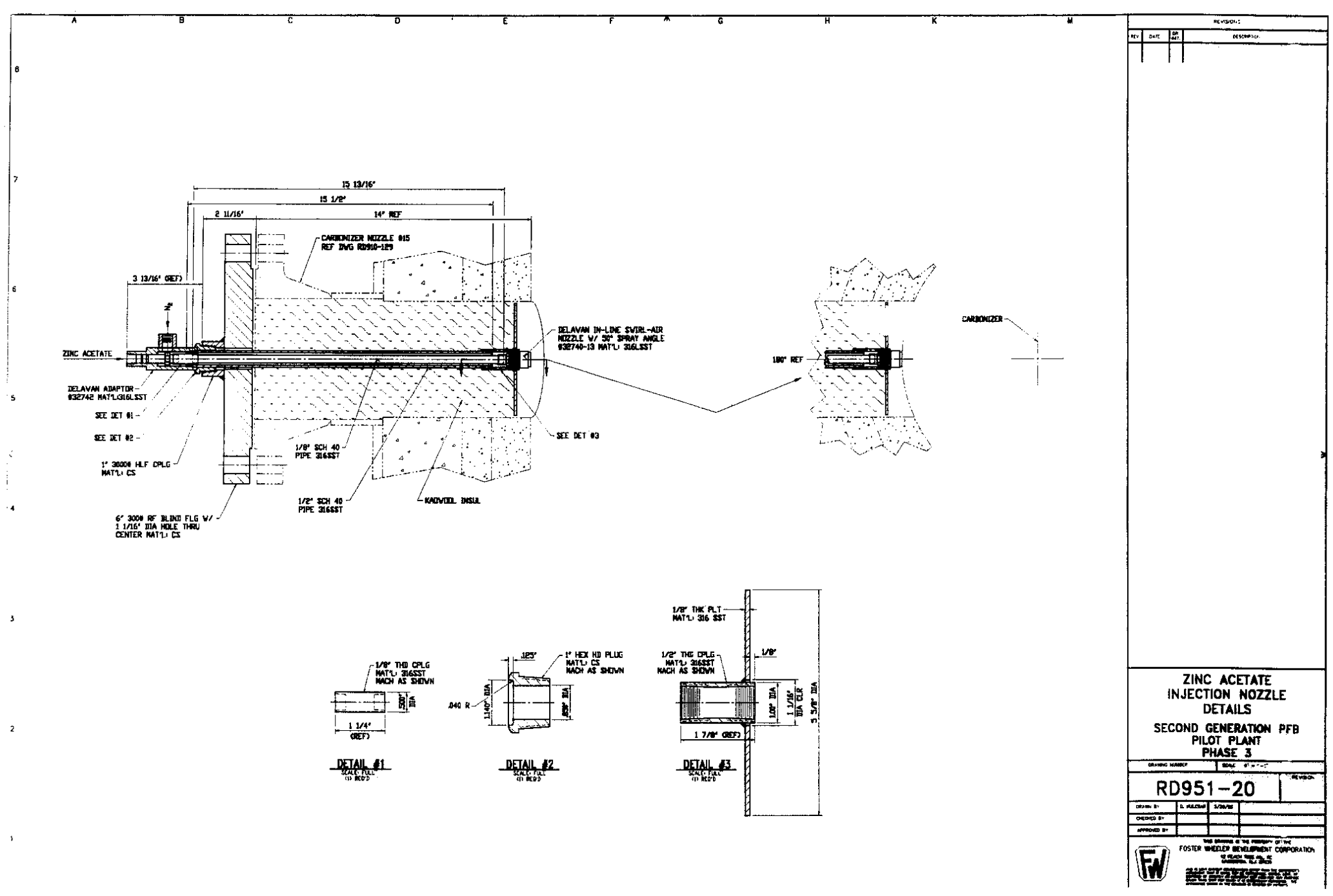

Figure 3.6.1 Zinc Oxide Slurry Injection Nozzle Arrangement 
The zinc oxide slurries tests were performed during Test Runs TR04 and TR05 (see Figures 3.4.2 and 3.4.3). In Test Run TR04, the carbonizer was started with a sand bed and sorbent feed commenced simultaneously with coal feed at about 6:00 p.m. on September 16, 1997. After about 8 hours of operation, $\mathrm{H}_{2} \mathrm{~S}$ levels were at about $225 \mathrm{ppm}$ and over the next 20 hours decreased to steady state value of about $125 \mathrm{ppm}$, the latter corresponding to $93.7 \%$ sulfur capture efficiency. Injecting $\mathrm{ZnO}$ at a $\mathrm{Zn} / \mathrm{S}$ molar feed ratio of 2.0 reduced $\mathrm{H}_{2} \mathrm{~S}$ levels to about $100 \mathrm{ppm}$ and raised the overall sulfur capture efficiency to about 94.9\% (1-.063x 100/125). Increasing the feed ratio to 6.5 further reduced $\mathrm{H}_{2} \mathrm{~S}$ to about $25 \mathrm{ppm}$, for a carbonizer overall sulfur capture efficiency of about $98.7 \%$ (1-.063x25/125). Reducing the feed ratio to 4.3 allowed the $\mathrm{H}_{2} \mathrm{~S}$ to increase to about $60 \mathrm{ppm}$ for an overall sulfur capture efficiency of $97 \%$ (1$.063 \times 60 / 125)$.

In Test Run TR05 the carbonizer was started at 12:13 hours on September 23, 1997, with a bed of limestone rather than sand. Because the bed was totally filled with sorbent $\mathrm{H}_{2} \mathrm{~S}$ levels were minimal in the beginning and, as expected, increased with time as a portion of the limestone bed was displaced by char and a steady state char-used limestone composition was reached. $\mathrm{H}_{2} \mathrm{~S}$ levels are observed to line out at about $125 \mathrm{ppm}$ as in TR04. Although $\mathrm{ZnO}$ was injected at $\mathrm{Zn} / \mathrm{S}$ molar feed ratios of 2.2, 4.0, and 4.4, the slurry concentrations used this time were much more dilute and gains were marginal if at all. Returning to TR04, the injection of water without zinc oxide into the syngas was observed to about double the $\mathrm{H}_{2} \mathrm{~S}$ level, increasing it from about 125 $\mathrm{ppm}$ to $210 \mathrm{ppm}$. The water vapor raises the equilibrium partial pressure of $\mathrm{H}_{2} \mathrm{~S}$ over calcium oxide/ calcium carbonate and causes $\mathrm{H}_{2} \mathrm{~S}$ to be released from the calcium sulfide $(\mathrm{CaS})$ entrained in the the gas stream and collected in the ash cake in the candle filter. The large quantity of water sprayed into the syngas in TR05 thus appears to have negated the gains provided by the zinc oxide; hence, commercial plant injections should be done with slurries containing high solids contents ( 15 weight per cent and higher) or use dry injection systems to maximize sulfur capture efficiency.

\subsection{Syngas Alkali Vapor Measurements}

In 1987 Westinghouse Science and Technology Center (WSTC) conducted equilibrium calculations to determine the amount of alkali vapor that could be released to the carbonizer syngas from Pittsburgh No. 8 coal and dolomite [3-2]. WSTC's calculations indicated the reducing conditions of the carbonizer enhance the release of alkali which appear as chlorides at levels well in excess of suggested gas turbine limits. Reducing the syngas temperature, however, will reduce the alkali level as shown in WSTC's Figure 3.7.1. To protect the Lakeland gas turbine from alkali induced corrosion, the carbonizer syngas will be cooled to $1200 \mathrm{EF}$ by a tubular heat exchanger located between the syngas cyclone and ceramic candle filter. This cooling will cause alkali vapor to condense on the fine particulate entrained in the syngas; the particulate will be captured/removed from the syngas by the candle filter thereby protecting the gas turbine. Although Figure 3.7.1 is insightful, equilibrium calculations are dependent on the assumptions and compounds taken into consideration and generally over predict gas phase alkali levels. In addition, these calculations do not account for alkali absorption by the coal fly ash and sorbent, which tend to reduce gas phase alkali levels, or the distribution of the alkali within the feedstocks which, together with operating conditions, affect the actual alkali release. As a result, 
alkali measurements were made in the Livingston carbonizer pilot plant to determine the range of syngas alkali levels expected at Lakeland with Kentucky No. 9 and Florida limestone.

The vapor phase measurements were made at a point approximately 6 feet downstream of the candle filter outlet nozzle (see Figure 3.7.2) via a probe supplied by Westinghouse and used by Foster Wheeler in a previous test program. Since alkali levels in the parts per billion range are to be measured and since the vapor has been shown by other investigators to be absorbed by the stainless steel tubing used to extract gas samples, WSTC has developed a probe that minimizes gas sample heat loss and extraction run length; in addition the probe can be used, depending upon tip configuration, for either isokinetic particle or alkali gas sampling. The Westinghouse probe flow and sampling arrangements are shown in Figures 3.7.3 and 3.7.4.

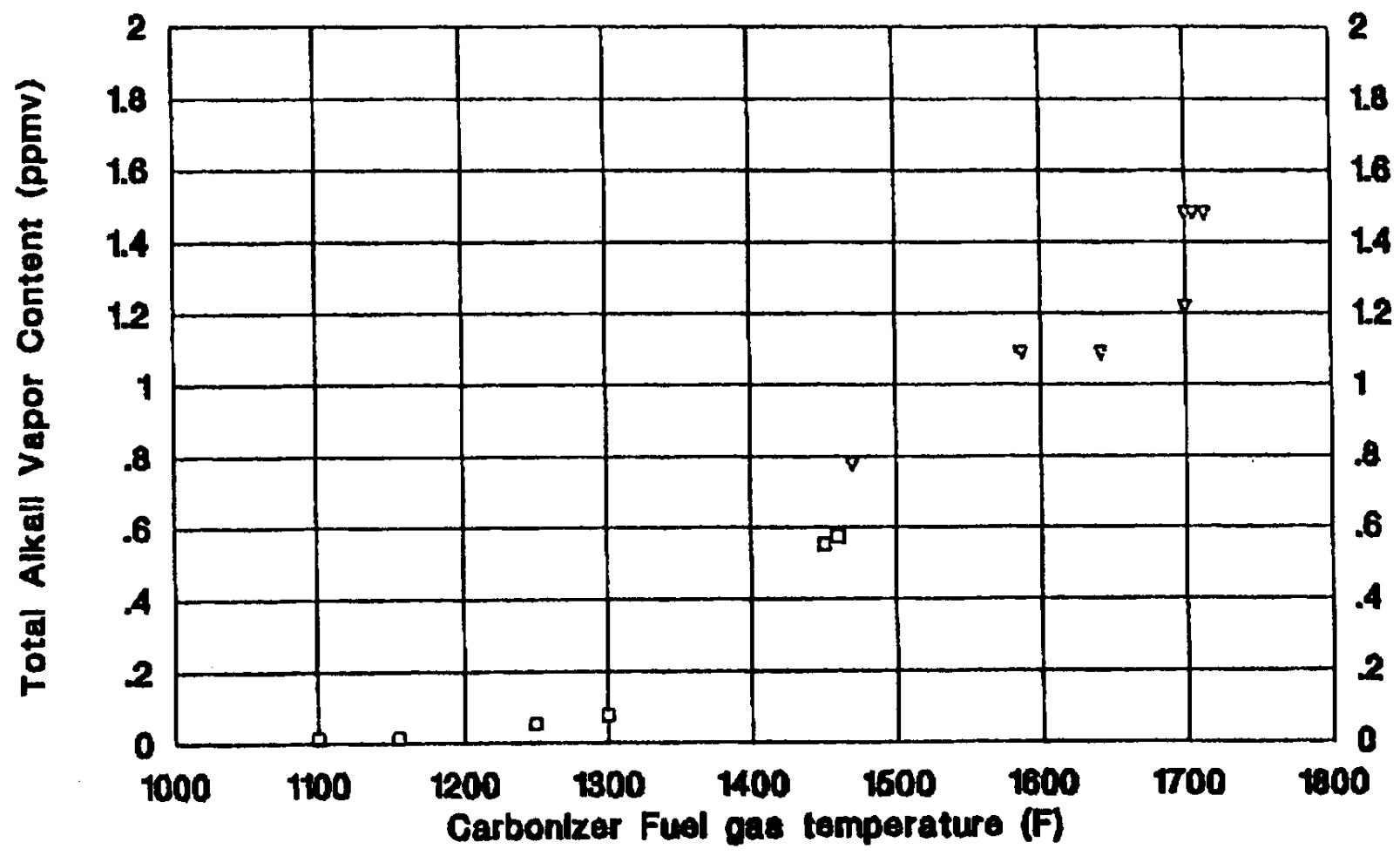

Figure 3.7.1 Syngas Equilibrium Total Alkali Vapor Estimate 


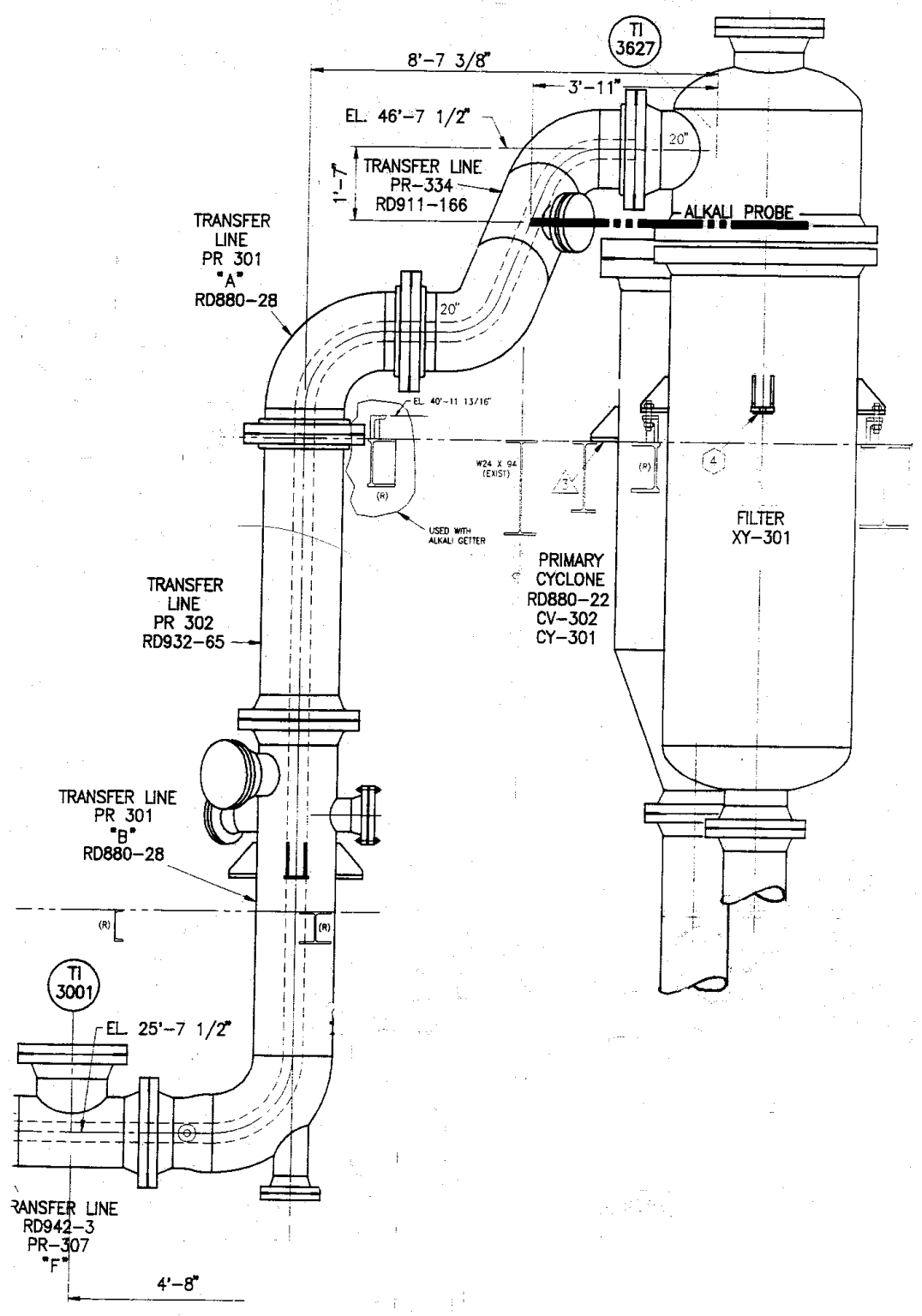

Figure 3.7.2 Location of Carbonizer Syngas Alkali Measurements 


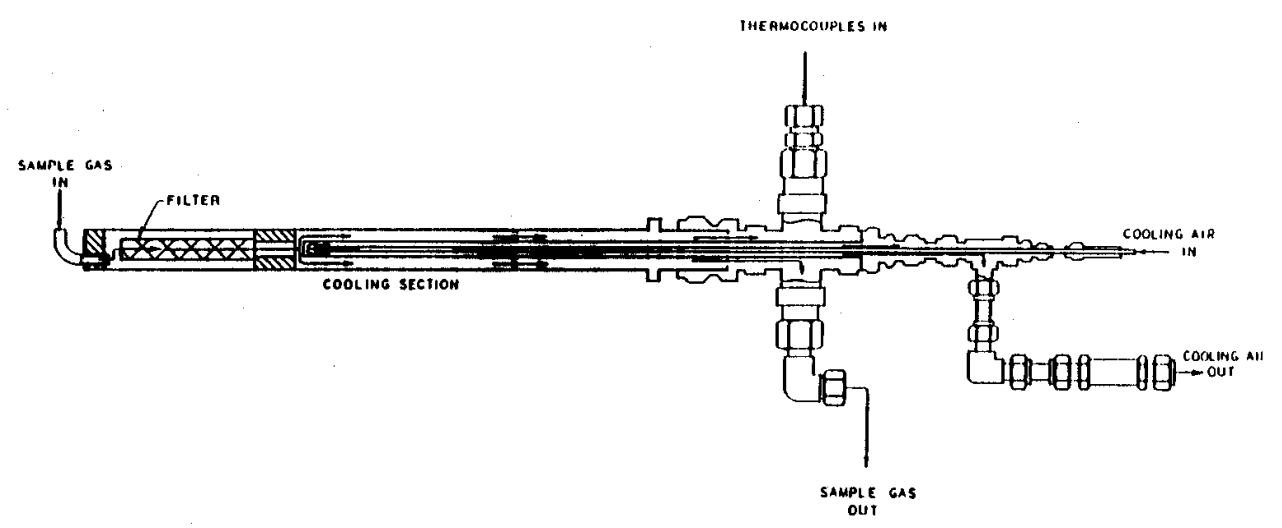

Figure 3.7.3 WSTC Typical Probe Flow Arrangement

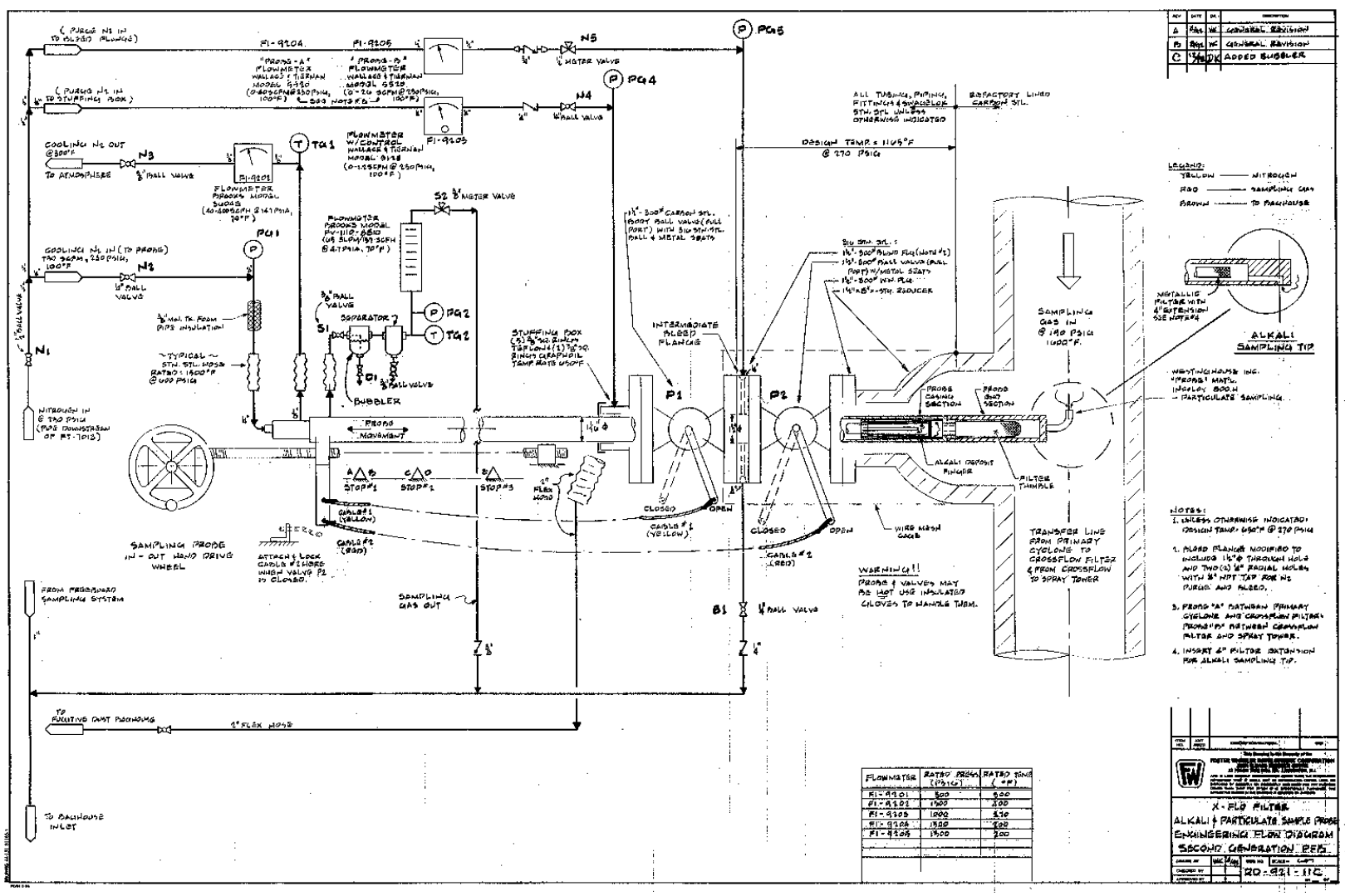

Figure 3.7.4 WSTC Alkali Probe Sampling Arrangement 
The alkali configured probe draws a non-isokinetic sample (typically about 1 ACFM) through a high-temperature, 5 micron, porous metal (Hastelloy X) thimble-shaped filter provided in the tip of the probe to remove particulate. The gas then passes into the cooling section of the probe to condense and collect alkali. Cooling is achieved by a continuous counter flow of high-pressure nitrogen in the inner concentric tube assembly. The sample gas passes through the outer annulus and cools to approximately $200 \mathrm{EF}$ with the alkali vapor condensing on the walls. The cooled gas exits the probe, passes through a bubbler, moisture separator/ knockout pot, rotameter, flow control valve, and proceeds to the pilot plant stack gas incinerator. The control valve sets the gas sampling/extraction rate, as measured by the rotameter, and the bubbler solution is analyzed after each test point to collect any alkali that escaped the probe; the knockout pot liquid content was negligible and hence none was available for analysis. Any particulate collecting on the thimble filter will gradually reduce the sampling rate and to minimize dust pick up during alkali measurements, the probe is oriented to face away from the flowing gas (Figure 3.7 5). In addition, the rotameter sampling rate is checked every five minutes and the control valve is adjusted accordingly to maintain the 1 ACFM sampling rate.

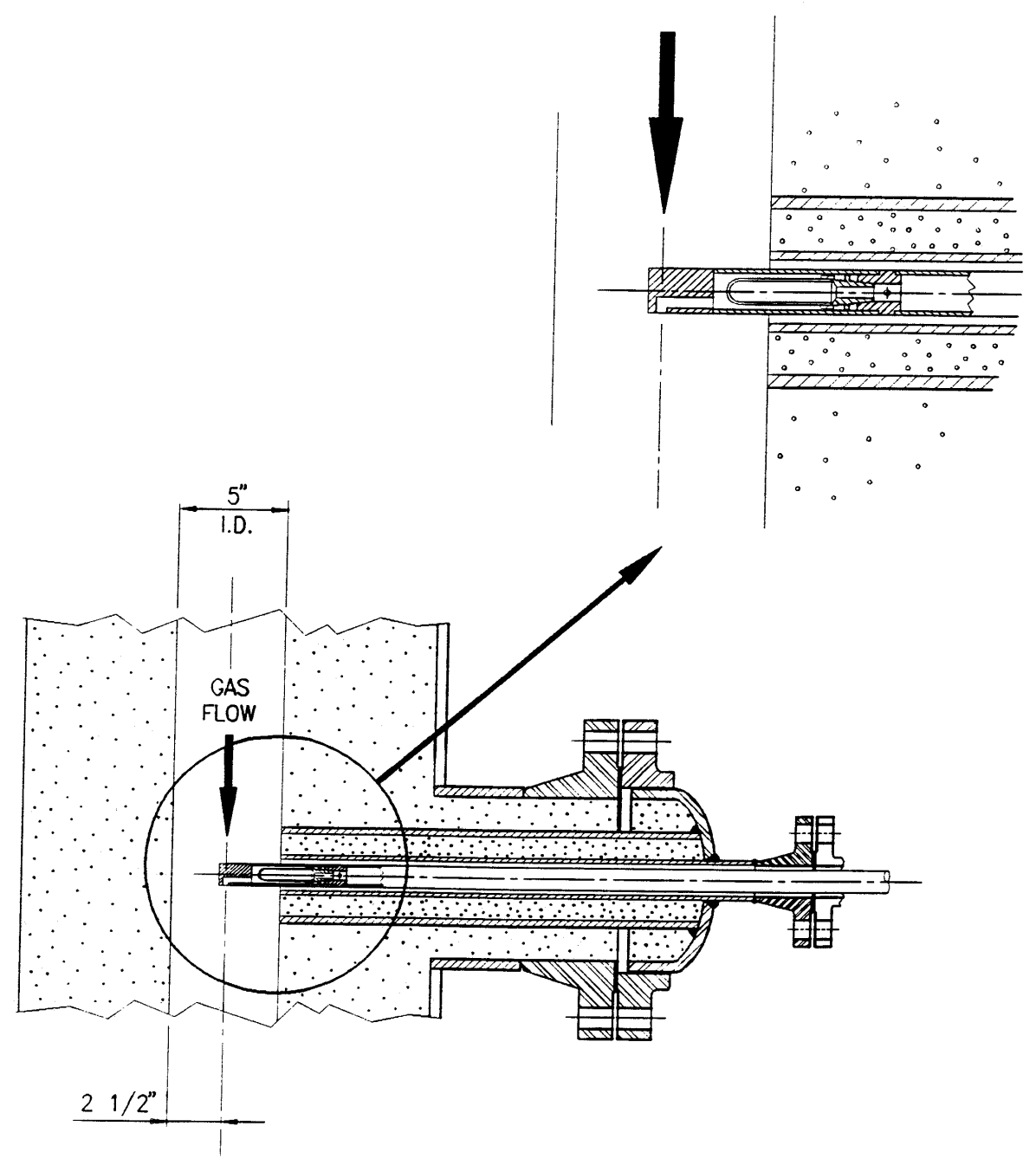

Figure 3.7.5 WSTC Probe with Alkali Sampling Tip 
After a sufficient sampling time period (typically about one hour), the probe is withdrawn from the syngas stream through a double block-and-bleed-valve arrangement (see Figure 3.7.4.). The probe is disassembled and appropriate sections brought in sealed plastic bags to the laboratory for analysis. Care must be taken at all times when handling the sections (a white glove operation) to prevent contamination of the specimens by dust or even perspiration as these can distort test results. Specimen handling and analyses are performed using WSTC developed/ recommended procedures. The particulate collected by and brushed off the porous metal thimble filter was weighted and where possible characterized to identify water-soluble and insoluble components. Alkali compounds were recovered from the thimble filter and cold finger using a rinse and recovery approach and these amounts, together with that obtained from the bubbler solution, were separately measured. On-site analyses were completed by selective-ion electrodes, atomic absorption, or inductively coupled plasma spectroscopy.

The gas temperature at the exact point of sampling was not measured during the Lakeland tests but can be inferred from nearby thermocouples. A thermocouple (TI 3001) located approximately 34 feet downstream of the filter outlet nozzle typically ran $110 \mathrm{EF}$ cooler than the filter outlet plenum. Based on this observation, the sampling point gas temperature, which is located approximately $6 \mathrm{ft}$. downstream of the filter, was about $20 \mathrm{EF}$ lower $(110 \times 6 / 34)$ than the filter outlet plenum temperature.

A total of 17 gas alkali measurements were made during 3 carbonizer test runs (TR4, 6, and 7) at carbonizer bed temperatures of $1725 \mathrm{EF}, 1750 \mathrm{EF}$ and $1810 \mathrm{EF}$ as determined by a thermocouple located 12.5 feet above the top of the central feed pipe. Being a pilot plant, the carbonizer, cyclone, candle filter, and piping have a high surface to volume rate. As a result, heat loss through the walls of these components yielded a candle filter outlet temperature that was about 400 to $500 \mathrm{EF}$ lower than the bed temperature and closely approximated the proposed Lakeland filter temperature. Hence, a syngas cooler was not installed in the Livingston pilot plant.

Tables 3.7.1 and 3.7.2 present the alkali data. During the alkali measurements, no dust leaks were experienced with the upstream candle filter and the particulate captured by the probe filter was so minimal it generally couldn't be checked for alkali content. As seen from Table 3.7.1 each thimble exhibited a weight gain during its one-hour sampling period and that experienced by thimble AK07 is close to the average gain. To understand the cause of the gain a transverse cut was made through thimble AK07 and examination of the exposed surfaces revealed:

1. by an Optical Microscope and a Scanning Electron Microscope (SEM) respectively, that entrapped dust particles were on the outside surface of the thimble filter.

2. Closer examination revealed no dust particles inside the porous thimble filter.

3. Energy dispersive $\mathrm{x}$-ray (EDS) analysis disclosed that the dust particles consisted of carbon, aluminum, silicon, sodium, sulfur, calcium, potassium, and titanium all of which are present in the test coal and limestone.

4. Recognizing that the thimble was exposed to the carbonizer syngas for only about an hour, no oxide or sulfide films were found on the thimble base metal.

Based on the above it was concluded that the thimble weight gains were caused by particulate trapped in the outer pores of the thimble, rather than by corrosion of the thimble. The water 
soluble alkali washed from the thimble filter and finger and that captured by the bubbler were added together and reported as the vapor phase alkali contained in the gas stream exiting the filter. The water soluble alkali that was extracted from the dust fines was not included in the vapor phase alkali summation as it is assumed it had condensed on the particulate upstream of and within the candle filter. Since the thimble filter contained particulate trapped in its outer pores, its washings tend to overestimate the vapor phase alkali content and since it yields conservative results no attempt was made to correct for this. Figure 3.7.6 plots the alkali vapor levels versus the candle filter outlet temperature for the 17 measurements and Figure 3.7.7 expands the vertical, condensed alkali scale. 
Table 3.7.1

Table 4 Alkali Sampling Summary for Lakeland Test TR04 to TR07 (Sep. to Dec. 1997)

\begin{tabular}{|c|c|c|c|c|c|c|c|c|c|c|c|c|c|c|c|c|c|c|c|}
\hline \multirow{2}{*}{$\begin{array}{l}\text { Set } \\
\text { Point }\end{array}$} & \multirow{2}{*}{$\begin{array}{l}\text { Sample } \\
\text { No. }\end{array}$} & \multirow{2}{*}{$\begin{array}{l}\text { Date } \\
\text { (m/d) }\end{array}$} & \multicolumn{3}{|c|}{ Time } & \multicolumn{2}{|c|}{ Carbonizert } & \multicolumn{2}{|c|}{ Candle Filtert } & \multicolumn{6}{|c|}{ Total Sampled/Collected } & \multirow{2}{*}{$\begin{array}{l}\text { Tpp } \\
\text { position }\end{array}$} & \multicolumn{2}{|c|}{ Flow meter } & \multirow[b]{2}{*}{$\begin{array}{r}\text { Fread } \\
\text { (liter) }\end{array}$} \\
\hline & & & $\begin{array}{l}\text { Start } \\
\text { (h:m) }\end{array}$ & $\begin{array}{l}\text { End } \\
\text { (h:mi) }\end{array}$ & $\begin{array}{r}\text { Dura. } \\
\text { (min) }\end{array}$ & $\begin{array}{r}\text { T3016 } \\
\text { (F) }\end{array}$ & $\begin{array}{r}\text { T3003 } \\
(\mathbf{r})\end{array}$ & $\begin{array}{r}\text { P3007 } \\
\text { (psig) }\end{array}$ & $\begin{array}{r}\mathrm{T} 3627 \\
\text { (F) }\end{array}$ & $\mathrm{lb}_{\mathrm{h}}^{\mathrm{G}}$ & (MW) & & $\begin{array}{l}\mathbf{t}^{*} \\
\mathrm{ppmw})\end{array}$ & $\begin{array}{r}\text { Vapor } \\
\text { (mg) }\end{array}$ & $\begin{array}{l}\text { Alknli } \\
\text { (pprnw) }\end{array}$ & & $\begin{array}{r}\text { PG2 } \\
\text { (psig) }\end{array}$ & $\begin{array}{r}\text { TG2 } \\
\text { (F) }\end{array}$ & \\
\hline TR07. & AK02 & $12 / 10 / 97$ & $15: 35$ & $16: 35$ & 60 & 1727 & 1660 & 174 & 1230 & 4738 & 26.8 & 0.125 & 26.3 & 0.195 & 0.041 & down & 145 & 104 & 3730 \\
\hline TR05. & AKO1 z & $09 / 24 / 97$ & 09:02 & 10:02 & 60 & 1745 & 1709 & 124 & 1320 & 6246 & 26.1 & 0.001 & 0.1 & 0.287 & 0.046 & down & 83 & 108 & 4860 \\
\hline TR0s. & AK 02 z & $09 / 24 / 97$ & $13: 29$ & $14: 29$ & 60 & 1757 & 1718 & 126 & 1316 & 5832 & 26.1 & 0.021 & 3.5 & 0.168 & 0.029 & dom & 80 & 104 & 4538 \\
\hline TR05. & AK04 & $09 / 25 / 97$ & $02: 20$ & $03: 20$ & 60 & 1756 & 1734 & 137 & 1368 & 4602 & 26.1 & 0.036 & 7.8 & 4.107 & 0.892 & down & 128 & 84 & 3581 \\
\hline TR05. & AK05 & $09 / 25 / 97$ & $04: 10$ & $05: 40$ & 90 & 1764 & 1745 & 139 & 1371 & 4584 & 26.1 & 0.042 & 9.1 & 0.422 & 0.092 & down & 126 & 80 & 3567 \\
\hline TR04. & AK01 & $09 / 17 / 97$ & $12: 45$ & $13: 40$ & 55 & 1759 & 1702 & 84 & 1264 & 5029 & 26.3 & 0.099 & 19.6 & 0.595 & 0.118 & & 60 & 97 & 3921 \\
\hline TR04. & AK02 & $09 / 17 / 97$ & $17: 11$ & 18:06 & 55 & 1760 & 1706 & 86 & 1259 & 5369 & 26.3 & 0.085 & 15.9 & 0.589 & 0.110 & dow & 75 & 95 & 4186 \\
\hline TR04. & AK03 & $09 / 17 / 97$ & $19: 39$ & $20: 39$ & 60 & 1758 & 1707 & 87 & 1262 & 5414 & 26.3 & 0.061 & 11.3 & 9.738 & 1.799 & dor & 79 & 97 & 4222 \\
\hline TR04. & AK04 & $09 / 17 / 97$ & $22: 20$ & $23: 20$ & 60 & 1763 & 1703 & 94 & 1282 & 6590 & 26.3 & 0.067 & 10.2 & 0.096 & 0.015 & dow & 82 & 116 & 5139 \\
\hline TR04. & AK05 & $09 / 18 / 97$ & $01: 40$ & $02: 40$ & 60 & 1753 & 1705 & 94 & 1283 & 6326 & 26.3 & 0.071 & 11.2 & 0.080 & 0.013 & dox & 91 & 125 & 4933 \\
\hline TR04. & AKO6: & $09 / 18 / 97$ & $09: 19$ & $10: 14$ & 55 & 1759 & 1697 & 93 & 1280 & 5954 & 26.3 & 0.068 & 11.4 & 45.71 & 7.678 & down & 79 & 110 & 4642 \\
\hline TR04: & AKO 7 z & $09 / 18 / 97$ & $11: 59$ & 12.54 & 55 & 1761 & 1679 & 95 & 1264 & 6064 & 26,3 & 0.063 & 10.3 & 0.045 & 0.007 & down & 83 & 132 & 4729 \\
\hline TR04. & AK08 & $09 / 18 / 97$ & $23: 20$ & $00: 20$ & 60 & 1814 & 1745 & 99 & 1296 & 6803 & 26.3 & 0.079 & 11.6 & 0.212 & 0.031 & & 84 & 101 & 5306 \\
\hline TR04. & AK09 & $09 / 19 / 97$ & $02: 25$ & $03: 25$ & 60 & 1823 & 1752 & 102 & 1299 & 6860 & 26.3 & 0.073 & 10.7 & 0.249 & 0.036 & $d o v$ & 86 & 100 & 5351 \\
\hline TR04. & AK10 & $09 / 19 / 97$ & $04: 35$ & 05:30 & 55 & 1803 & 1741 & 106 & 1304 & 5311 & 26.3 & 0.061 & 11.5 & 0.222 & 0.042 & down & 82 & 91 & 4143 \\
\hline TR04. & AK11 z & $09 / 19 / 97$ & $08: 53$ & $09: 48$ & 55 & 1817 & 1732 & 110 & 1287 & 6779 & 26.3 & 0.059 & 8.7 & 0.155 & 0.023 & dow & 102 & 104 & 5288 \\
\hline TR04. & AK12 & $09 / 19 / 97$ & $13: 30$ & $14: 25$ & 55 & 1796 & 1747 & 110 & 1311 & 6550 & 26.3 & 0.017 & 2.5 & 0.910 & 0.139 & down & 93 & 100 & 5109 \\
\hline
\end{tabular}

Note:

Vapor Alkali means alkali from thimble, cold finger, and bubbler.

* - sum of the dust fine collected and weight gain by thimble; ppmw is only for reference since isokinetic sampling was not used.

+ - both temperature and pressure are the average value in the alkali sampling period.

$Z$ - ZnO injection during measurement.

T3016 is the temperature at $12^{\prime} 61 / 8^{\prime \prime}$ above the top of feed pipe, T3003 \& P3007 are freeboard tempexature \& pressure are at 32' $61 / 8^{\prime \prime} \& 31^{\prime} 1 / 8^{\prime \prime}$ above feed pipe respecti

Probe filters are metalicic (Hastelloy $X$ ) with pore size of 5 micron.

All tests used Kentucky coal with Florida limestone.

PG2 and TG2 represent the averaged pressure and temperature of sample gas at the rotameter inlet.

Gâs flow lb/h is corrected for fuel gas molecular weight by (MWair/MWg) ${ }^{n} .5$.

Flow meter reading (liter) is accunulated air flow averaged for each 5 minutes $\&$ oorrected for pressure and temperature by $\left[((14.7+\mathrm{PG} 2) / 14.7)^{*}(530 /(460+\mathrm{TG} 2))\right]^{\wedge} .5$.

MWair = 28.96 MWgas is each set point averaged test data corrected for $\mathrm{N} 2$ leakage. 
Table 3.7.2

Table 5 Alkali Sample Chemical Analysis Summary for Lakeland Test TR04 to TR07 (Sep. to Dec. 1997)

\begin{tabular}{|c|c|c|c|c|c|c|c|c|c|c|c|c|c|c|c|c|c|c|c|c|c|c|c|}
\hline \multirow{3}{*}{$\begin{array}{l}\text { Set } \\
\text { Point }\end{array}$} & \multirow{3}{*}{$\begin{array}{c}\text { Sample } \\
\text { No. }\end{array}$} & \multicolumn{6}{|c|}{ Dust fine } & \multicolumn{7}{|c|}{ Thimble } & \multicolumn{3}{|c|}{ Finger* } & \multicolumn{2}{|c|}{ Bubbler* } & \multirow{3}{*}{$\begin{array}{l}\text { Sum } \\
\text { (mg) }\end{array}$} & \multicolumn{3}{|c|}{ Vapor } \\
\hline & & \multicolumn{2}{|c|}{$\mathrm{Na}$} & \multicolumn{2}{|c|}{ K } & \multirow{2}{*}{$\begin{array}{l}\text { Sum wh } \\
\text { (mg) }\end{array}$} & \multirow{2}{*}{$\begin{array}{l}\text { wh of } \\
\text { dust } \\
\text { (mg) }\end{array}$} & \multirow{2}{*}{$\begin{array}{r}\text { Ratio } \\
\text { sontwt } \\
(\%)\end{array}$} & \multirow{2}{*}{\multicolumn{2}{|c|}{$\begin{array}{l}\mathrm{Na}^{\mathrm{Na}} \\
\text { Sol Ins } \\
(\mathrm{mg})(\mathrm{mg})\end{array}$}} & \multirow{2}{*}{$\begin{array}{c}\text { Kol } \\
\text { Solns } \\
\text { (mg) (mg) }\end{array}$} & \multirow{2}{*}{$\begin{array}{l}\text { Sum } \\
\text { (mg) }\end{array}$} & \multirow{2}{*}{$\begin{array}{l}\text { gain } \\
\text { gaing) }\end{array}$} & \multirow{2}{*}{$\begin{array}{r}\text { Ratio } \\
\text { Survwt } \\
(\%)\end{array}$} & \multirow{2}{*}{$\begin{array}{r}\mathrm{Na} \\
\mathrm{Sol} \\
(\mathrm{mg})\end{array}$} & \multirow{2}{*}{$\begin{array}{r}\mathrm{K} \\
\text { Sol } \\
(\mathrm{mg})\end{array}$} & \multirow{2}{*}{$\begin{array}{l}\text { Sum } \\
\text { (mg) }\end{array}$} & \multirow{2}{*}{$\begin{array}{r}\mathrm{Na} \\
\text { Sol } \\
(\mathrm{mg})\end{array}$} & \multirow{2}{*}{$\begin{array}{r}\mathbf{K} \\
\text { Sol } \\
\text { (mg) }\end{array}$} & & \multirow{2}{*}{$\begin{array}{r}\mathrm{Na} \\
\mathrm{Sol} \\
(\mathrm{mg})\end{array}$} & \multirow{2}{*}{$\begin{array}{r}\mathbf{K} \\
\text { Sol } \\
\text { (mg) }\end{array}$} & \multirow[b]{2}{*}{$\begin{array}{l}\text { Sum } \\
\text { (mg) }\end{array}$} \\
\hline & & $\begin{array}{r}\text { Sol } \\
(\mathrm{mg})\end{array}$ & $\begin{array}{r}\text { Ins } \\
(\mathrm{mg})\end{array}$ & $\begin{array}{r}\text { Sol } \\
(\mathrm{mg})\end{array}$ & $\begin{array}{r}\text { Ins } \\
\text { (mg) }\end{array}$ & & & & & & & & & & & & & & & & & & \\
\hline TR07. & AK02 & 0.026 & 0.088 & 0.002 & 0.227 & 0.343 & $17 \theta$ & 0.31 & 0.0160 & - & 0.0050 & -0.021 & 14.1 & 0.15 & 0.1140 & 0.0200 & 0.134 & 0.0200 & 0.0200 & 0.040 & 0.150 & 0.045 & 0.195 \\
\hline TR05. & AK01 $\mathrm{z}$ & - & - & - & - & 0.000 & $0 . \theta$ & $B R R$ & 0.0400 & - & 0.0005 & -0.041 & 0.7 & 5.79 & 0.0240 & 0.0005 & 0.025 & 0.1470 & 0.0745 & 0.222 & 0.211 & 0.076 & 0.287 \\
\hline TR05. & AK02 2 & - & - & - & - & 0.000 & 2.3 & 0.00 & 0.0170 & - & 0.0005 & -0.018 & 28.2 & 0.10 & 0.0650 & 0.0520 & 0.117 & 0.0210 & 0.0120 & 0.033 & 0.103 & 0.065 & 0.168 \\
\hline TR0s. & AK04 & - & - & - & - & 0.000 & 30.5 & 0.00 & 0.0003 & . & 0.0005 & -0.001 & 25.4 & 0.00 & 0.0560 & 0.0200 & 0.076 & 4.0200 & 0.0100 & 4.030 & 4.076 & 0.031 & 4.107 \\
\hline TR05. & AK05 & - & - & - & - & 0.000 & 3.4 & 0.00 & 0.0030 & - & 0.0005 & -0.004 & 36.1 & 0.01 & 0.0760 & 0.0520 & 0.128 & 0.2800 & 0.0100 & 0.290 & 0.359 & 0.063 & 0.422 \\
\hline TR04. & AK01 & 4.840 & 0.130 & 0.030 & 0.220 & 5.220 & 28.8 & 18.1 & 0.0270 & - & 0.0005 & -0.028 & 69.7 & 0.04 & 0.0010 & 0.0005 & 0.002 & 0.0160 & 0.5500 & 0.560 & 0.044 & 0.551 & 0.595 \\
\hline TR04. & AK02 & - & - & - & $\cdot$ & 0.000 & 206 & 0.00 & 0.0320 & - & 0.0000 & -0.038 & 74.9 & 0.05 & 0.0060 & 0.0010 & 0.007 & 0.0140 & 0.5300 & 0.544 & 0.052 & 0.537 & 0.589 \\
\hline TR04. & AK03 & - & - & - & . & 0.000 & 3.9 & 0.00 & 0.0310 & - & 0.0140 & -0.045 & 57.3 & 0.08 & 0.0040 & 0.0030 & 0.007 & 9.6600 & 0.0260 & 9.686 & 9.695 & 0.043 & 9.738 \\
\hline TR04. & AK04 & - & - & - & - & 0.000 & 1.3 & 0.00 & 0.0260 & - & 0.0240 & -0.050 & 65.6 & 0.08 & 0.0110 & 0.0350 & 0.046 & - & - & 0.000 & 0.037 & 0.059 & 0.096 \\
\hline TR04. & AK05 & - & - & - & - & 0.000 & 0.0 & $B R R$ & 0.0200 & - & 0.0210 & $-0.04 I$ & 71.0 & 0.06 & 0.0190 & 0.0200 & 0.039 & - & - & 0.000 & 0.039 & 0.041 & 0.080 \\
\hline TR04. & AK06 z & - & - & - & - & 0.000 & 6.3 & 0.00 & 0.0520 & - & 0.0240 & -0.076 & 61.8 & 0.12 & 0.0100 & 0.0170 & 0.027 & 45.500 & 0.1110 & 45.61 & 45.56 & 0.152 & 45.71 \\
\hline TR04. & $\operatorname{AK07}_{\mathrm{z}}$ & - & - & - & - & 0.000 & 0.7 & 0.00 & 0.0010 & - & 0.0110 & -0.012 & 61.9 & 0.02 & 0.0010 & 0.0130 & 0.014 & 0.0010 & 0.0180 & 0.019 & 0.003 & 0.042 & 0.045 \\
\hline TR04. & AK08 & - & . & - & - & 0.000 & 4.2 & 0.00 & 0.0005 & - & 0.0062 & 0.007 & 74.3 & 0.01 & 0.0280 & 0.0270 & 0.055 & 0.0100 & 0.1400 & 0.150 & 0.039 & 0.173 & 0.212 \\
\hline TR04. & AK09 & - & - & - & $\cdot$ & 0.000 & 4.9 & 0.00 & 0.0005 & - & 0.0068 & 0.007 & 68.5 & 0.01 & 0.0660 & 0.0360 & 0.102 & 0.0100 & 0.1300 & 0.140 & 0.077 & 0.173 & 0.249 \\
\hline TR04. & AK10 & - & - & - & $\cdot$ & 0.000 & 1.5 & 0.00 & 0.0005 & - & 0.0005 & -0.001 & 59.6 & 0.00 & 0.0210 & 0.0300 & 0.051 & 0.0100 & 0.1600 & 0.170 & 0.032 & 0.191 & 0.222 \\
\hline TR04. & AK11 z & - & - & - & - & 0.000 & 1.9 & 0.00 & 0.0005 & - & 0.0005 & -0.001 & 57.0 & 0.00 & 0.0190 & 0.0160 & 0.035 & 0.0090 & 0.1100 & 0.119 & 0.029 & 0.127 & 0.155 \\
\hline TR04. & AK12 & - & - & - & $\cdot$ & 0.000 & 0.0 & $E R R$ & 0.7380 & - & 0.0280 & -0.766 & 16.7 & 4.59 & 0.0100 & 0.0140 & 0.024 & 0.0100 & 0.1100 & 0.120 & 0.758 & 0.152 & 0.910 \\
\hline & $\begin{array}{l}\text { "Sol" means } \\
\text { "Vapor = tot } \\
\text { "**11 means no } \\
\text { "-" means no } \\
\text { "Z" means Z } \\
\text { Other refer t }\end{array}$ & $\begin{array}{l}\text { al of th } \\
\text { insoly }\end{array}$ & $\begin{array}{l}\text { imble } \\
\text { uble al } \\
\text { cable. } \\
\text { ection }\end{array}$ & 48 & $\begin{array}{l}\text { and b } \\
\text { sent. }\end{array}$ & ubbler & $\mathrm{r}$ al & ali su & & & & & & & & & & & & & & & \\
\hline
\end{tabular}




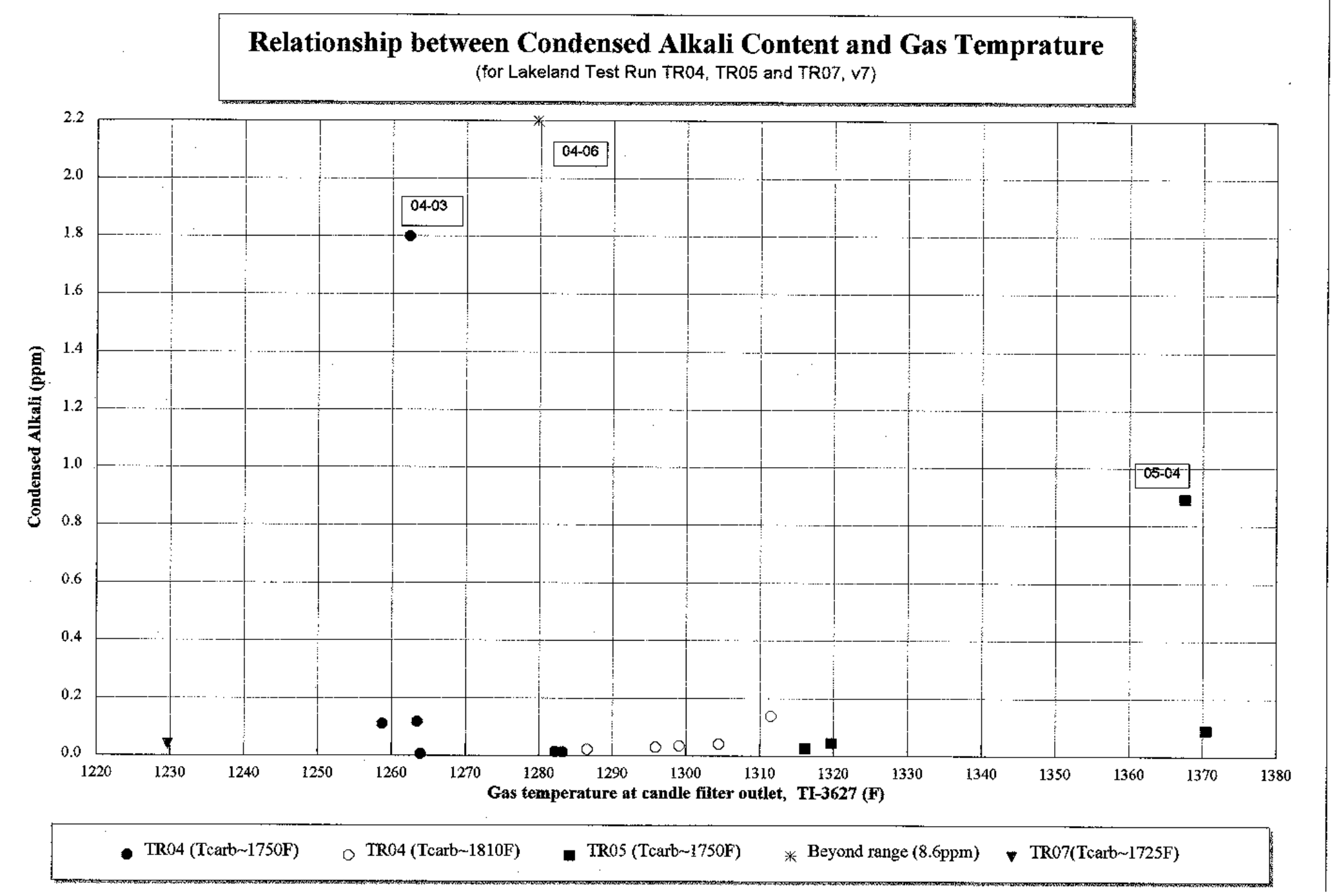

Figure 3.7.6 Syngas Alkali Vapor Level Versus Temperature 


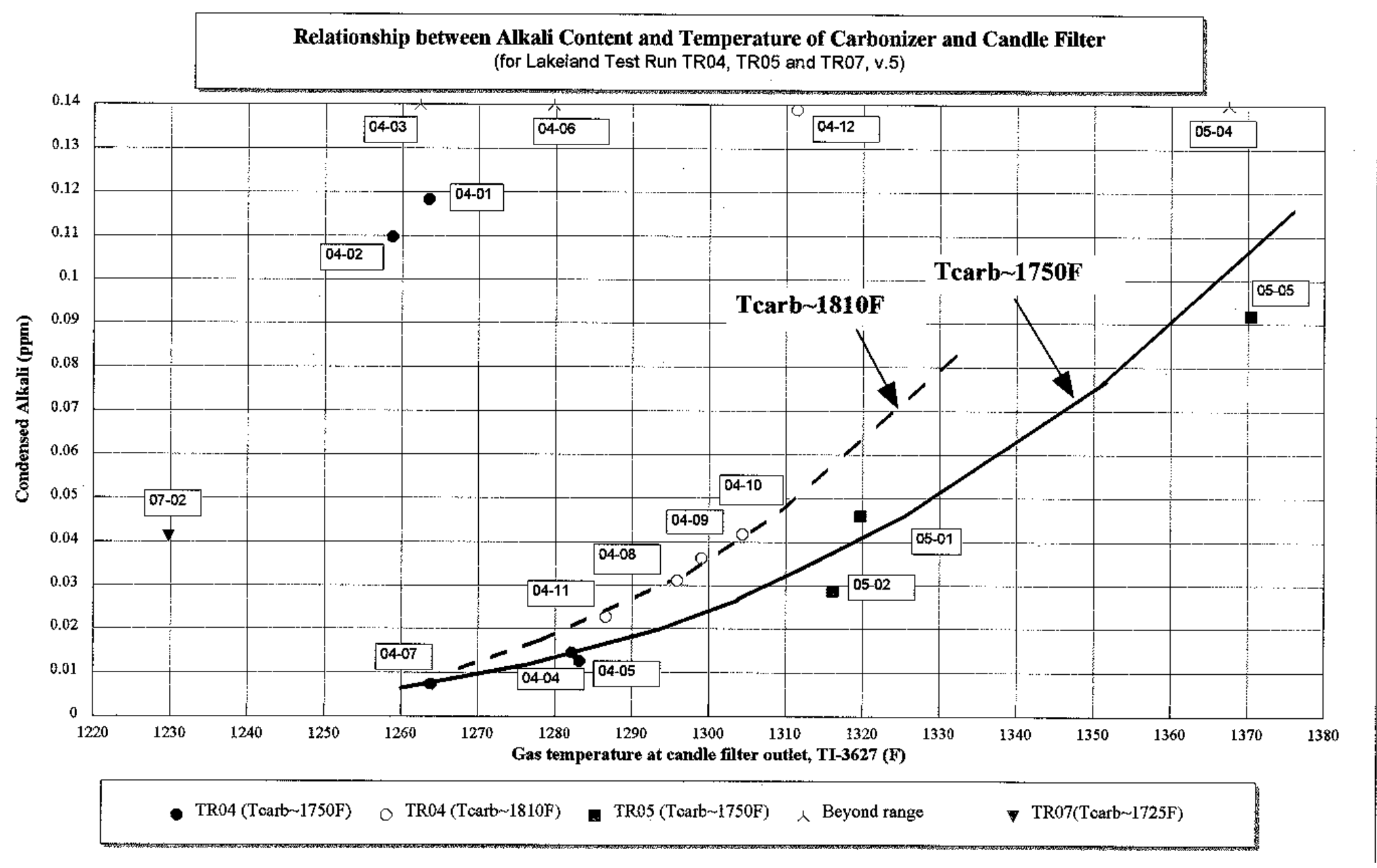

Figure 3.7.7 Syngas Alkali Vapor Level Versus Temperature (Expanded Scale) 
The alkali levels shown in Figure 3.7.7 are very low and accurate measurements at these levels are known to be difficult. Seven of the 17 points shown in this figure do not agree with the predicted theoretical trend and are one to two orders of magnitude greater than the other points. It is suspected those seven points were "bad" possibly reflecting specimen contamination. A check of published literature revealed that similar measurements had been made in a fluidized bed gasifier pilot plant in Finland [3-1]. The gasifier was a 6 inch diameter bubbling bed unit running at . $1750 \mathrm{EF}$ at 4 to 6 atmospheres pressure. The syngas generated by the gasifier passed through two stages of cyclones, a tubular heat exchanger/gas cooler, and a candle filter. Downstream of the candle filter syngas samples were extracted through an electrically heat traced line, cooled by water spray, depressured via a valve, passed through bubblers to condense the alkali, and vented to a flow meter. Although most of the testing was done using peat and wood as the fuels, some data was collected with the Illinois No. 6 coal shown in Table 3.7.3. Vapor phase alkali levels were found to be a function of the gasifier temperature, feed stock, and gas sampling temperature. The experimenter's results shown in Figure 3.7.8 exhibit the Figure 3.7.1 and 3.7.7 temperature relationship, and the peat and Illinois No. 6 alkali levels scatter for the most part from 50 to $100 \mathrm{ppbw}$ over the 932 to $1202 \mathrm{EF}$ temperature interval. The WSTC probe data shown in Figure 3.7.7 does not exhibit this scatter and, as a result, we suspect it to be the more accurate of the two techniques at these low levels. The Figure 3.7.7 WSTC probe data indicates vapor phase alkali levels should be less than $20 \mathrm{ppbw}$ at 1200EF, the planned operating temperature of the Lakeland syngas candle filter. 
Table 3.7.3 Gasifier and Feedstock Data Extracted from [3-1]

Technical Data of the VTT-PFG Test Facility

\begin{tabular}{|c|c|c|c|}
\hline Bed - I.D. & $15 \mathrm{~cm}$ & \multicolumn{2}{|l|}{ Feedstocks gasified: } \\
\hline Freeboard - I.D. & $25 \mathrm{~cm}$ & \multicolumn{2}{|l|}{ - Saw dust and wood wastes } \\
\hline Reactor height & $4.2 \mathrm{~m}$ & \multicolumn{2}{|l|}{ - Different peat product } \\
\hline & & \multicolumn{2}{|l|}{ - Rhenish brown coal } \\
\hline Operating pressure & 3-10 bar & \multicolumn{2}{|c|}{ - Hard coals: Iowa Rawhide, Polish Coal, Illinois No. 6} \\
\hline Bed temperature & 700-1000EC & Total pressurized test time & $1600 \mathrm{~h}$ \\
\hline Freeboard t (max) & $1100 \mathrm{EC}$ & Number of measured set points & 100 \\
\hline Fluidizing velocity & $0.5-1.5 \mathrm{~m} / \mathrm{s}$ & Amount of gasified fuels & 80 tons \\
\hline Gasification agents & Air, steam & Fuel feed rate (max) & $80 \mathrm{~kg} / \mathrm{h}$ \\
\hline
\end{tabular}

Feedstock Analyses

\begin{tabular}{|c|c|c|c|c|c|c|c|}
\hline & Pine & & & Rhenish & Iowa & & Illinois \\
\hline & $\begin{array}{l}\text { saw } \\
\text { dust }\end{array}$ & Peat A & Peat B & $\begin{array}{c}\text { brown } \\
\text { coal }\end{array}$ & $\begin{array}{c}\text { Rawhide } \\
\text { coal }\end{array}$ & $\begin{array}{c}\text { Polish } \\
\text { coal }\end{array}$ & $\begin{array}{l}\text { No.6 } \\
\text { coal }\end{array}$ \\
\hline Moisture content, wt $\%$ & $5-11$ & $9-16$ & $15-19$ & $11-13$ & $17-19$ & $5-7$ & $2-5$ \\
\hline \multicolumn{8}{|l|}{ Proximate analysis (d.b) } \\
\hline Volatile matter, wt $\%$ & 83.0 & 72.7 & 68.4 & 53.0 & 43.2 & 31.8 & 33.9 \\
\hline Fixed carbon, wt $\%$ & 16.8 & 24.3 & 27.4 & 42.7 & 49.5 & 59.9 & 53.2 \\
\hline Ash, wt $\%$ & 0.2 & 3.0 & 4.3 & 4.3 & 7.4 & 8.3 & 13.2 \\
\hline \multicolumn{8}{|l|}{ Ultimate analysis (d.b) } \\
\hline $\mathrm{C}, \mathrm{wt} \%$ & 50.2 & 50.1 & 54.5 & 63.8 & 70.8 & 75.5 & 64.6 \\
\hline $\mathrm{H}, \mathrm{wt} \%$ & 6.1 & 5.4 & 5.6 & 4.6 & 4.7 & 4.7 & 4.2 \\
\hline $\mathrm{N}, \mathrm{wt} \%$ & 0.1 & 0.8 & 1.8 & 0.8 & 0.7 & 1.3 & 1.3 \\
\hline $\mathrm{S}, \mathrm{wt} \%$ & 0.0 & 0.1 & 0.2 & 0.3 & 0.5 & 0.7 & 2.9 \\
\hline Ash, wt $\%$ & 0.2 & 3.0 & 4.3 & 4.3 & 7.4 & 8.3 & 13.2 \\
\hline $\mathrm{O}$ (diff.), wt $\%$ & 43.4 & 40.6 & 33.6 & 26.2 & 16.2 & 9.5 & 13.8 \\
\hline Na content, ppm-wt (d.b) & 40 & 380 & 330 & 300 & 1140 & 450 & 1420 \\
\hline K content, ppm-wt (d.b) & 500 & 690 & 440 & 140 & 570 & 1420 & 3610 \\
\hline Cl content, ppm-wt (d.b) & $<15$ & 180 & 270 & 250 & $<25$ & 760 & 1210 \\
\hline
\end{tabular}




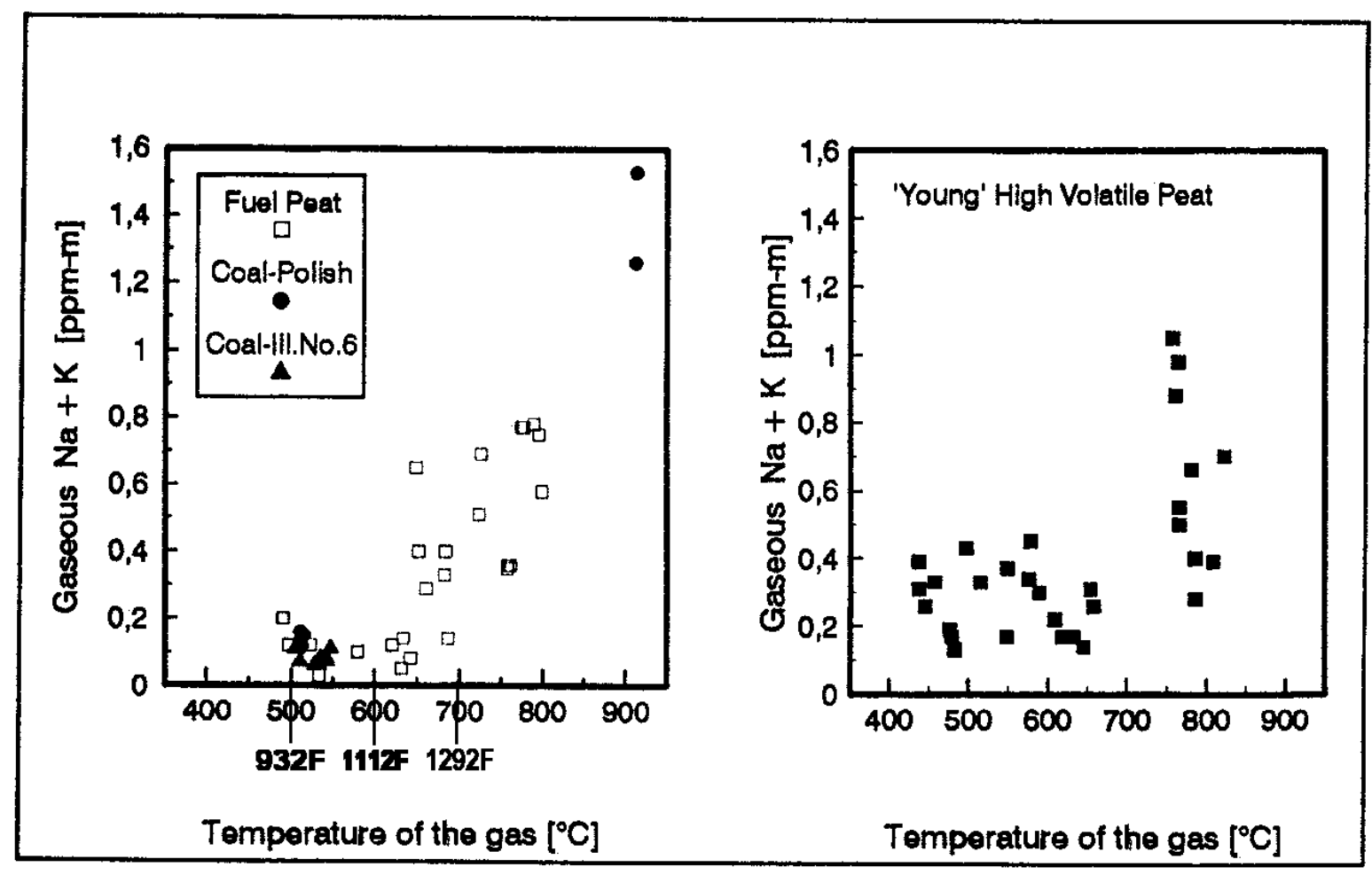

Figure 3.7.8 Alkali Results Extracted from [3-1]

Alkali measurements have also been made at several PFB test facilities utilizing other techniques. Although the PFB flue gas is oxidizing rather than reducing, similar temperature trends and minimal alkali levels are predicted by theory at $1200 \mathrm{EF}$. The alkali measurements that were made at the outlet of the Asahi ceramic candle filter in the 71 MWe Wakamatsu nontopped PFB plant compared two different measuring techniques. The first used Argonne National Laboratory's bed of activated bauxite to capture the alkali vapor (AASB Method) and after a specified exposure period the bed was analyzed to determine its alkali content. In the second method a sample of gas was continuously passed through a flame that was monitored by a calibrated atomic emissions spectrometer (FAES Method). Tables 3.7.4 and 3.7.5 and Figure 3.7.9 present the published Wakamatsu data [3-3]. For the PFB vitiated air (oxidizing) conditions they too predict a decrease in alkali vapor with decreasing gas temperatures. Figure 3.7.9 depicts this temperature trend and presents alkali measurement data from other facilities. The gas sampling point temperatures during the second and third Wakamatsu test periods ranged from 642 to $650 \mathrm{EC}$ (1188 to $1202 \mathrm{EF}$ ) and the alkali vapor ranged from 0 to 5 ppbw depending upon the measuring method used. Some experimenters have observed a time dependency on gas alkali vapor levels indicating an increase with time attributed to a gradual decrease in vapor absorption by upstream equipment surfaces. Eventually a pseudo-equilibrium is expected to be reached, but the time required to achieve it is uncertain and will depend on test rig size. The Wakamatsu data is believed to have been taken after about 4500 hours of operation (1800 hours with the ceramic filter) and hopefully has reached this equilibrium condition. The WSTC probe data shown in Figure 3.7.7 indicates, depending upon the bed temperature, vapor phase alkali levels ranging from about 30 to $50 \mathrm{ppbw}$; with a higher bed temperature (1750 to $1810 \mathrm{EF}$ vs. 
$1560 \mathrm{EF}$ ) and reducing gas conditions involved, the syngas data could be expected to be and does appear to be slightly higher than the oxidizing 1560EF PCFB data. The fact that the difference is in the right direction is encouraging.

Table 3.7.4 Wakamatsu Fuel and Test Conditions from [3-3]

Test Conditions and Sampling Results

\begin{tabular}{|c|c|c|c|c|}
\hline & First Run & Second Run & Third Run & Fourth Run \\
\hline Operating Load & $100 \%$ Load & $54 \%$ Load & $54 \%$ Load & $100 \%$ Load \\
\hline $\begin{array}{l}\text { Buming Cous (by suknery with } \\
\text { water and linestonne) }\end{array}$ & $\begin{array}{l}\text { Taiheiyo 50\% } \\
\text { Blainthol } 50 \%\end{array}$ & Blairthol $100 \%$ & Taineiyo $100 \%$ & Blairthol $100 \%$ \\
\hline Bed Temperature & $830-860^{\circ} \mathrm{C}$ & $850-860^{\circ} \mathrm{C}$ & $847-851^{\circ} \mathrm{C}$ & $834-845^{\circ} \mathrm{C}$ \\
\hline Bed Pressure & $1.013 \mathrm{MPa}$ & $0.728 \mathrm{MPa}$ & $0.728 \mathrm{MPa}$ & $1.033 \mathrm{MPa}$ \\
\hline $\begin{array}{l}\text { Gas Temperature at } \\
\text { Sampling Point }\end{array}$ & $780-800^{\circ} \mathrm{C}$ & $650-660^{\circ} \mathrm{C}$ & $640-642^{\circ} \mathrm{C}$ & $793 \cdot 804^{\circ} \mathrm{C}$ \\
\hline $\begin{array}{l}\text { Gas Pressure at } \\
\text { Sampling Point }\end{array}$ & $0.974 \mathrm{MPa}$ & $0.689 \mathrm{MPa}$ & $0.689 \mathrm{MPa}$ & $0.974 \mathrm{MPa}$ \\
\hline $\begin{array}{l}\text { Sampling Period for } \\
\text { AASB sampling }\end{array}$ & $44.5 \mathrm{~h}$ & $46.5 \mathrm{~h}$ & $50.0 \mathrm{~h}$ & $19.8 \mathrm{~h}$ \\
\hline $\begin{array}{l}\text { Total Sampling gas } \\
\text { quantity }\end{array}$ & $109 \mathrm{Nm} 3$ & $109 \mathrm{Nm} 3$ & $120 \mathrm{Nm} 3$ & $22 \mathrm{Nm} 3$ \\
\hline $\begin{array}{l}\text { Condensed water quantity in } \\
\text { in samping unit }\end{array}$ & Approx. $14 \ell$ & Approx. $11 \ell$ & Approx.9.5 l & Approx. $2.2 \mathrm{l}$ \\
\hline
\end{tabular}

Chemical Analysis of the Coal Slurry Burnt During Measurement

\begin{tabular}{|c|c|c|c|c|c|}
\hline & & First Run & Second Run & Third Run & Fourth Run \\
\hline \multirow{9}{*}{ 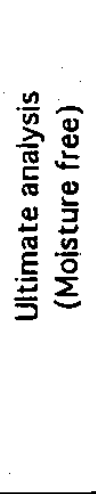 } & C (\%) & 59.6 & 67.1 & 64.6 & 68.5 \\
\hline & $H(\%)$ & 4.46 & 3.85 & 5.37 & 4.05 \\
\hline & $O(\%)$ & 18.43 & 12.69 & 13.48 & 14.19 \\
\hline & $N(\%)$ & 1.10 & 1.48 & 0.95 & 1.62 \\
\hline & S (\%) & 0.23 & 0.21 & 0.19 & 0.28 \\
\hline & Ash (\%) & 16.3 & 14.67 & 15.54 & 11.39 \\
\hline & $P(\%)$ & 0.019 & 0.011 & 0.029 & 0.014 \\
\hline & $C(\mathrm{mg} / \mathrm{kg})$ & 260 & 250 & 380 & 230 \\
\hline & $F(\mathrm{mg} / \mathrm{kg})$ & 30 & 10 & 20 & 20 \\
\hline \multirow{2}{*}{$\frac{5}{\frac{n}{n}} \frac{\frac{n}{n}}{\frac{\pi}{n}}$} & $\mathrm{Na}_{2} \mathrm{O}(\%)$ & 0.51 & 0.38 & 1.38 & 0.40 \\
\hline & $\mathrm{K}_{2} \mathrm{O}(\%)$ & 0.44 & 0.16 & 0.98 & 0.27 \\
\hline
\end{tabular}


Table 3.7.5 Wakamatsu Oxidizing PFB Flue Gas and Alkali Results from [3-3]

Exhaust Gas Analysis Result (at Gas Turbine Outlet)

\begin{tabular}{|l|c|c|c|c|}
\hline & First Run & Second Fun & Third Run & Fourth Run \\
\hline Moisture (Vol. \%) & 11.8 & 8.9 & 10.0 & 11.8 \\
\hline Specific weight $\left(\mathrm{kg} / \mathrm{Nm}^{3}\right)$ & 1.29 & 1.29 & 1.29 & 1.29 \\
\hline Dust concentration $\left(\mathrm{g} / \mathrm{Nm}^{3}\right)$ & 0.0135 & 0.0014 & 0.0017 & 0.0036 \\
\hline $\mathrm{SO}_{2}$ concentration $(\mathrm{ppm})$ & 9.7 & 3.8 & 11.2 & 13.4 \\
\hline $\mathrm{SO}_{3}$ concentration $(\mathrm{ppm})$ & 0.45 & 1.0 & 2.8 & 2.4 \\
\hline $\mathrm{Hcl}$ concentration $(\mathrm{ppm})$ & 1.7 & 3.5 & 12.7 & 5.7 \\
\hline
\end{tabular}

\section{Measurement Result of Alkali Vapor in Wakamatsu PFBC}

[UNIT: ppo wt]

\begin{tabular}{|c|c|c|c|c|c|}
\hline & & First Run & Second Run & Thisd Run & Fourth Run \\
\hline \multirow{7}{*}{ 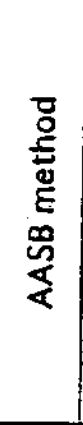 } & Sodium vapor concentration & $17.5-28.0$ & $0 \cdot 6.5$ & 3.4 & 8.9 \\
\hline & Potassium vapor concentration & $0.5-5.0$ & $0 \cdot 1.5$ & 0.0 & 1.5 \\
\hline & Sodtum concentration in fly ash & $0 \cdot 0.5$ & 0.0 & 0.0 & 0.0 \\
\hline & $\begin{array}{l}\text { Polassium concentration in Hy } \\
\text { ash }\end{array}$ & 0.0 & 0.0 & 0.0 & 0.0 \\
\hline & Total sodhem concentration & $17.5 \cdot 28.5$ & $0 \cdot 6.5$ & 3.4 & 8.9 \\
\hline & Total potassium concentration & $0.5 \cdot 5.0$ & $0 \cdot 1.5$ & 0.0 & 1.5 \\
\hline & Total akkali vapor concentration & $18.0 \cdot 33.0$ & $0 \cdot 8.0$ & 3.4 & 10.4 \\
\hline \multirow{5}{*}{ 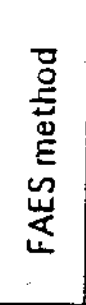 } & Sodlum vapor concentration & - & $1.9-3.7$ & $1.0 \cdot 3.2$ & $0.9-7.8$ \\
\hline & Potassium vapor concentration & - & $0.7-1.3$ & $0.3-0.7$ & $0.5 \cdot i .4$ \\
\hline & Sodium concentration in tly ash & - & (*) 13.2 & (*) 16.8 & (*) 14.3 \\
\hline & $\begin{array}{l}\text { Potassium concentration } \\
\text { infly_asth }\end{array}$ & - & $(*) 4.6$ & (*) 0.7 & $(*) 0.7$ \\
\hline & Total akall vapor concentration & - & $2.6 \cdot 5.0$ & $1.3-3.9$ & $1.4 \cdot 9.2$ \\
\hline \multirow{3}{*}{ 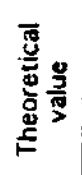 } & Sodtum vapor concentration & 6.0 & 0.12 & 0.26 & 6.58 \\
\hline & Potassium vapor concentration & 31.0 & 0.48 & 1.07 & 32.2 \\
\hline & Total akali vapor concentration & 37.0 & 0.6 & 1.33 & 38.8 \\
\hline
\end{tabular}

(") Peak value while puise cleaning of ceramic filter 


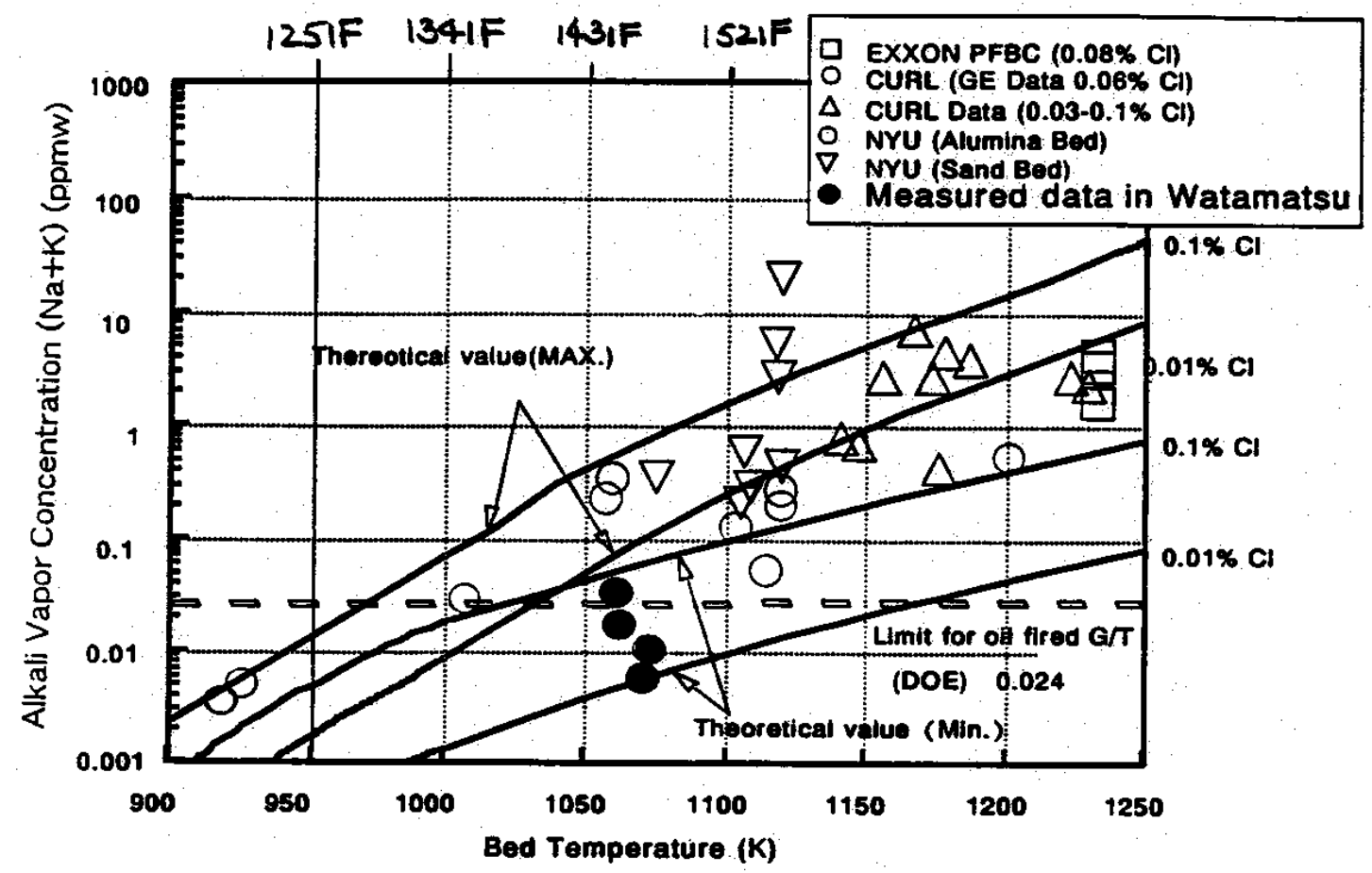

Alkali Vapor Measurement Results reported by various resesrch Organizations

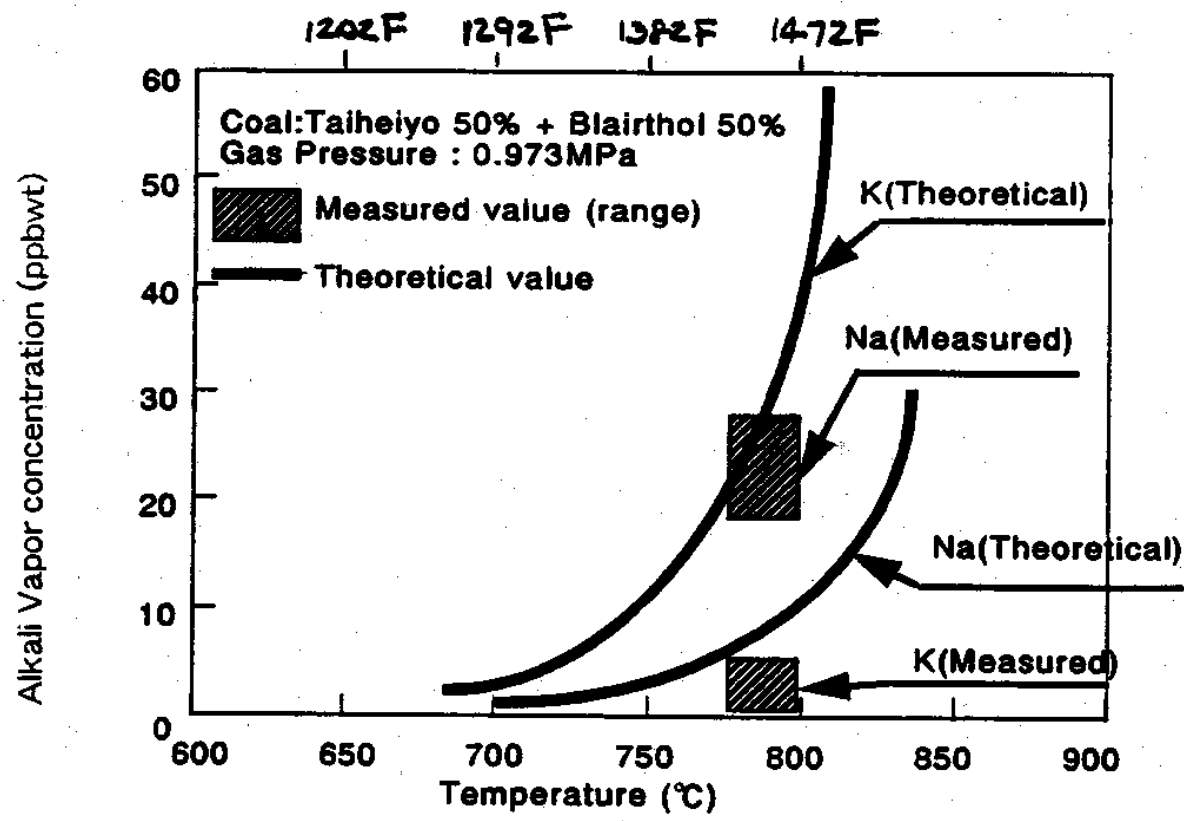

Theoreticcal Alkali Vapor Concentrations

Figure 3.7.9 Predicted and Observed Alkali Data in Oxidizing PFB flue Gas from [3-3] 


\subsection{Candle Filter}

The Westinghouse Ceramic Candle Filter used during the test is shown in Figure 4.1; it consisted of a 50 inch OD by $17 \mathrm{ft}$. -2 in. tall refractory lined vessel containing up to 22 candles split into two equal groupings. The candles were $2.36 \mathrm{in}$. in OD by $59 \mathrm{in}$. long and were hung from a metallic tube sheet in the cluster arrangement shown in Figure 4.2. Carbonizer syngas entered the vessel tangentially and flowed primarily over the top of a cylindrical shroud that protected the elements from direct gas impingement and promoted general downflow over the elements. The syngas passed through the porous wall of the candles, flowed up each candle, discharged into a plenum at the top of the unit, and exited through a $5 \mathrm{in}$. ID radial outlet nozzle. Particulate entrained in the syngas deposited on the outside of the candles and was blown off by intermittent pulses of high pressure nitrogen emanating from the inside of each candle. The dislodged dust cake fell to the bottom of the unit and drained by gravity through a 6 in. Sch 40 outlet to surge and lock hoppers provided beneath the unit.

During the fine sorbent test runs TR4 and 5, the filter was operated without a pre-cleaning cyclone and all material elutriated from the carbonizer bed entered the filter. Anticipating a high solids loading, these runs were conducted with all 22 candles installed and candles manufactured by Coors were used. For the coarse sorbent test runs TR6 and 7, a pre-cleaning cyclone was installed immediately upstream of the filter and, anticipating a lighter solids loading, only 10 candles were installed (5 Schumacher candles in the first cluster and 5 Pall Refraction candles in the second). The particulate captured by the cyclone drained through a "J" valve/loop seal to the surge hopper provided under the filter. 


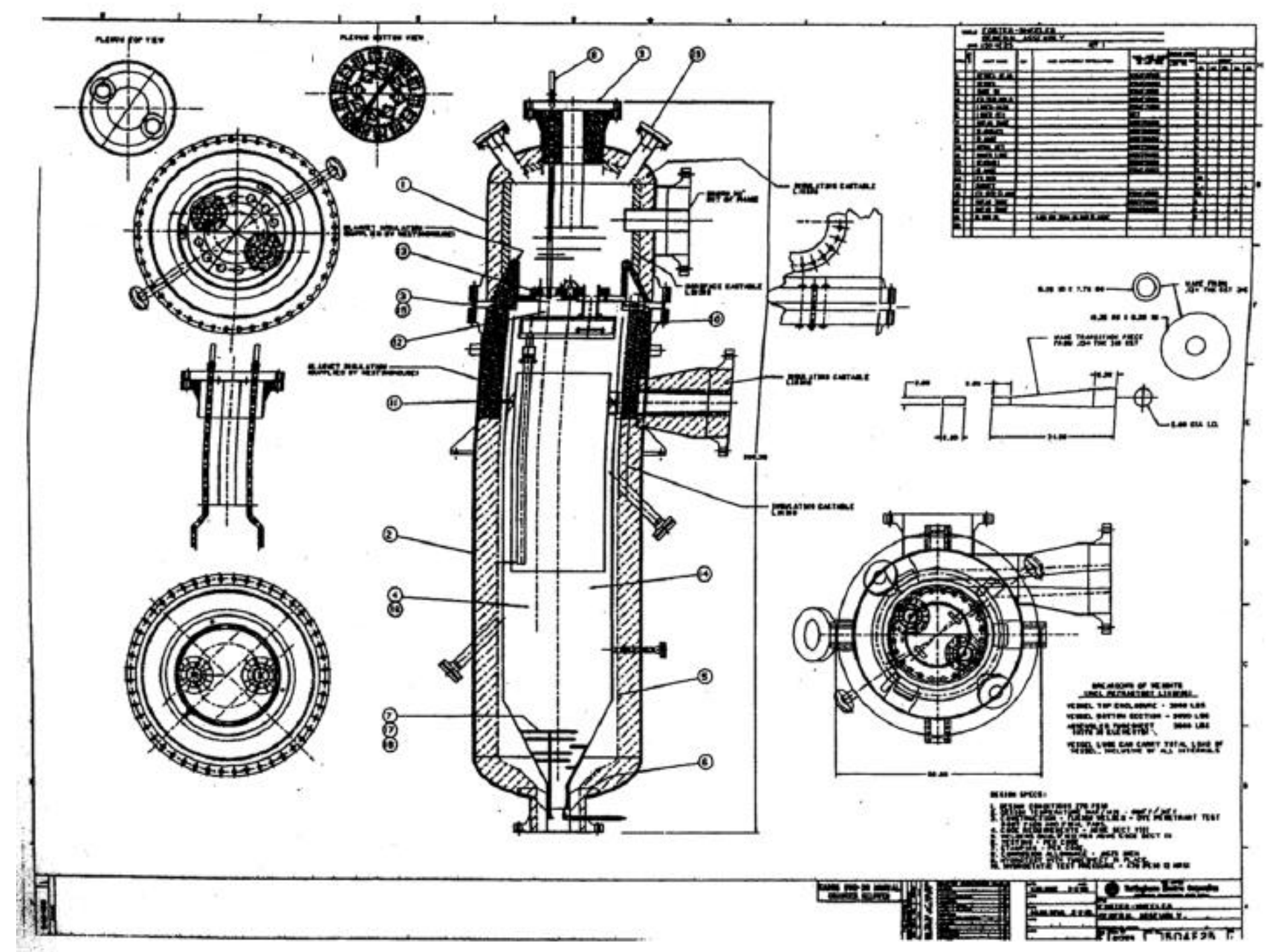

Figure 4.1 Candle Filter Layout 


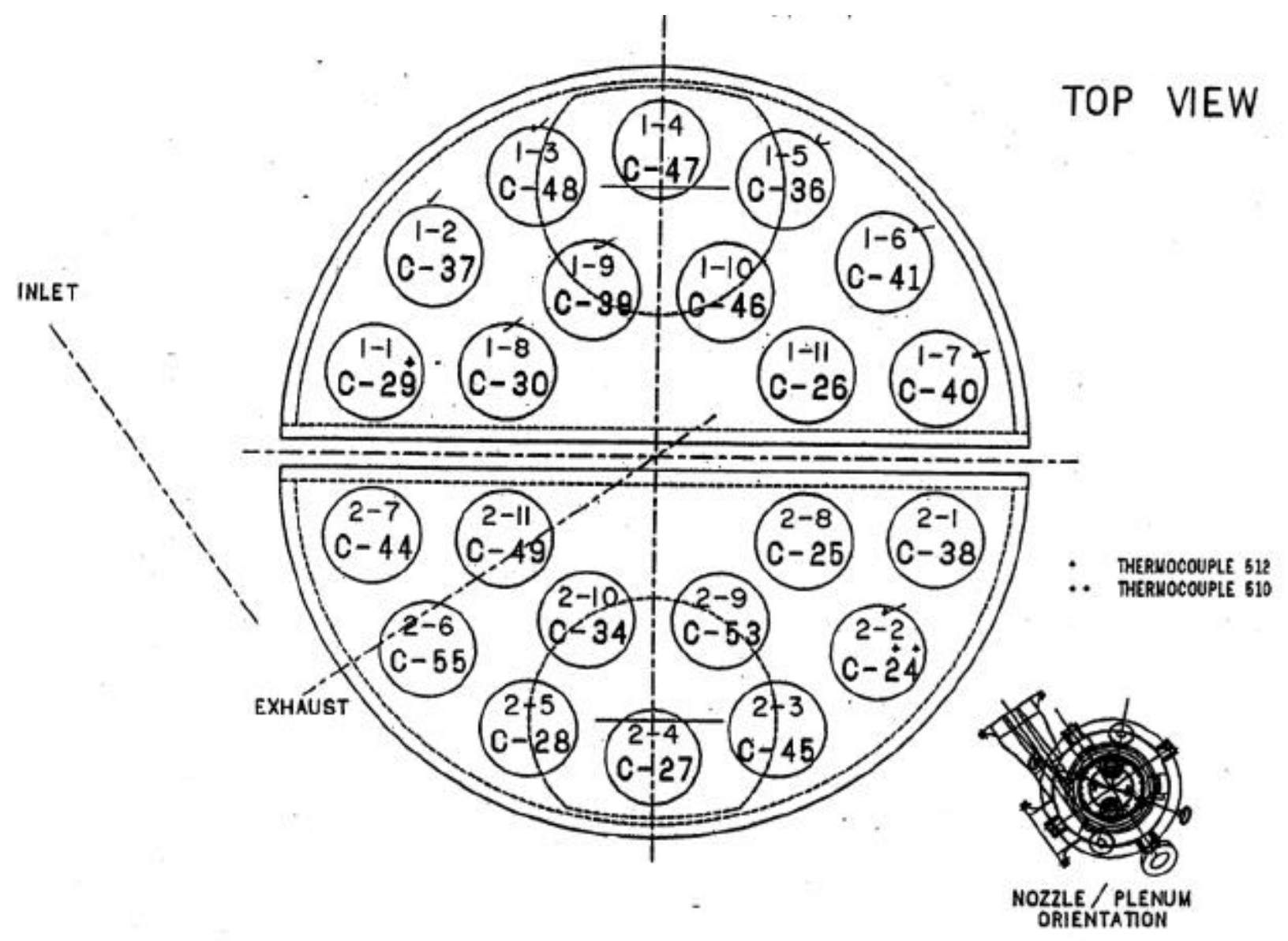

Figure 4.2 Candle Arrangement - Plan View 
Table 4.1 tabulates the filter operating conditions and it is seen the 22 candle system operated with a face velocity of approximately $1.9 \mathrm{fpm}$ with a solids loading ranging from $1.3(10)^{5}$ to $1.5(10)^{5}$ ppmw. With the 10 candle arrangement, the face velocity rose to approximately $4 \mathrm{fpm}$. Because the cyclone and filter shared the same surge and lock hoppers unlike TR4 and 5, the particulate loading to the filter in TR6 and 7 could not be calculated.

In all four test runs the filter operated successfully showing no signs of ash bridging or agglomeration.

Table 4.1 Candle Filter Performance

\begin{tabular}{|l|c|c|c|c|c|c|}
\hline Test Run & \multicolumn{2}{|c|}{4} & 5 & 6 & \multicolumn{2}{c|}{7} \\
\hline Set Point & 4.1 & 4.2 & 5.1 & 6.1 & 7.1 & 7.2 \\
\hline Pre-cleaning cyclone & No & No & No & Yes & Yes & Yes \\
\hline Solids drain rate, Ib/h & 149 & 149 & 182 & $\mathrm{NA}^{\vee}$ & $77^{*}$ & $101^{*}$ \\
\hline Syngas flow rate & 965 & 1082 & 1213 & 1460 & 1641 & 1597 \\
\hline Inlet pressure, psia & 104.7 & 119.5 & 136.3 & $\mathrm{NA}^{\vee}$ & 174.9 & 179.9 \\
\hline Inlet temperature, E F & 1390 & 1429 & 1441 & 1451 & 1407 & 1446 \\
\hline Syngas Mol Wt & 26.23 & 26.23 & 25.87 & $\mathrm{NA}^{\vee}$ & 27.50 & 26.76 \\
\hline Syngas Vol Flow, ACFM & 116.4 & 116.7 & 117.08 & $\mathrm{NA}^{\vee}$ & 114.05 & 113.20 \\
\hline Number of candles & 22 & 22 & 22 & 10 & 10 & 10 \\
\hline${\text { Candle filtration area } \mathrm{ft}^{2}}^{2}$ & 62.7 & 62.7 & 62.7 & 28.5 & 28.5 & 28.5 \\
\hline Candle face velocity, fpm $^{\text {Sandids loading, ppmw }}$ & 1.86 & 1.86 & 1.88 & $\mathrm{NA}^{L}$ & 4.0 & 3.97 \\
\hline Solid & $1.54(10)^{5}$ & $1.34(10)^{5}$ & $1.50(10)^{5}$ & --- & --- & --- \\
\hline
\end{tabular}

$\mathrm{NA}^{\mathrm{L}}=$ data not available

* Total collected by cyclone and filter

$+2.85 \mathrm{ft} 2$ of face/filtration area per candle

Typical filter performance data is presented for TR5 in Figures 4.3 and TR7 in Figure 4.4 where:

$\begin{array}{ll}\text { PI } 3007 & \text { carbonizer freeboard pressure } \\ \text { PI } 3603 & \mathrm{~N}_{2} \text { pulse tank pressure } \\ \text { PDI 3638 } & \text { Tube sheet pressure differential } \\ \text { TI 3049 } & \text { Syngas inlet temperature } \\ \text { TI 3109 } & \text { Solids drain temperature }\end{array}$

TI 3109 is a thermocouple located in the 6 in. solids drain nozzle at the bottom of the filter vessel, and its spikes reflect falling filter cake from the pulse cleaned candles. The 22 and 10 candle runs exhibit on the whole similar performance characteristics. In TR5 the pulse tank cleaning pressure was about $350 \mathrm{psi}$ above process, the cleaning pulse was triggered when the candle pressure drop reached about 50 in. of $\mathrm{H}_{2} \mathrm{O}$, and after cleaning the candle pressure drop was about 20 in. of $\mathrm{H}_{2} \mathrm{O}$. 


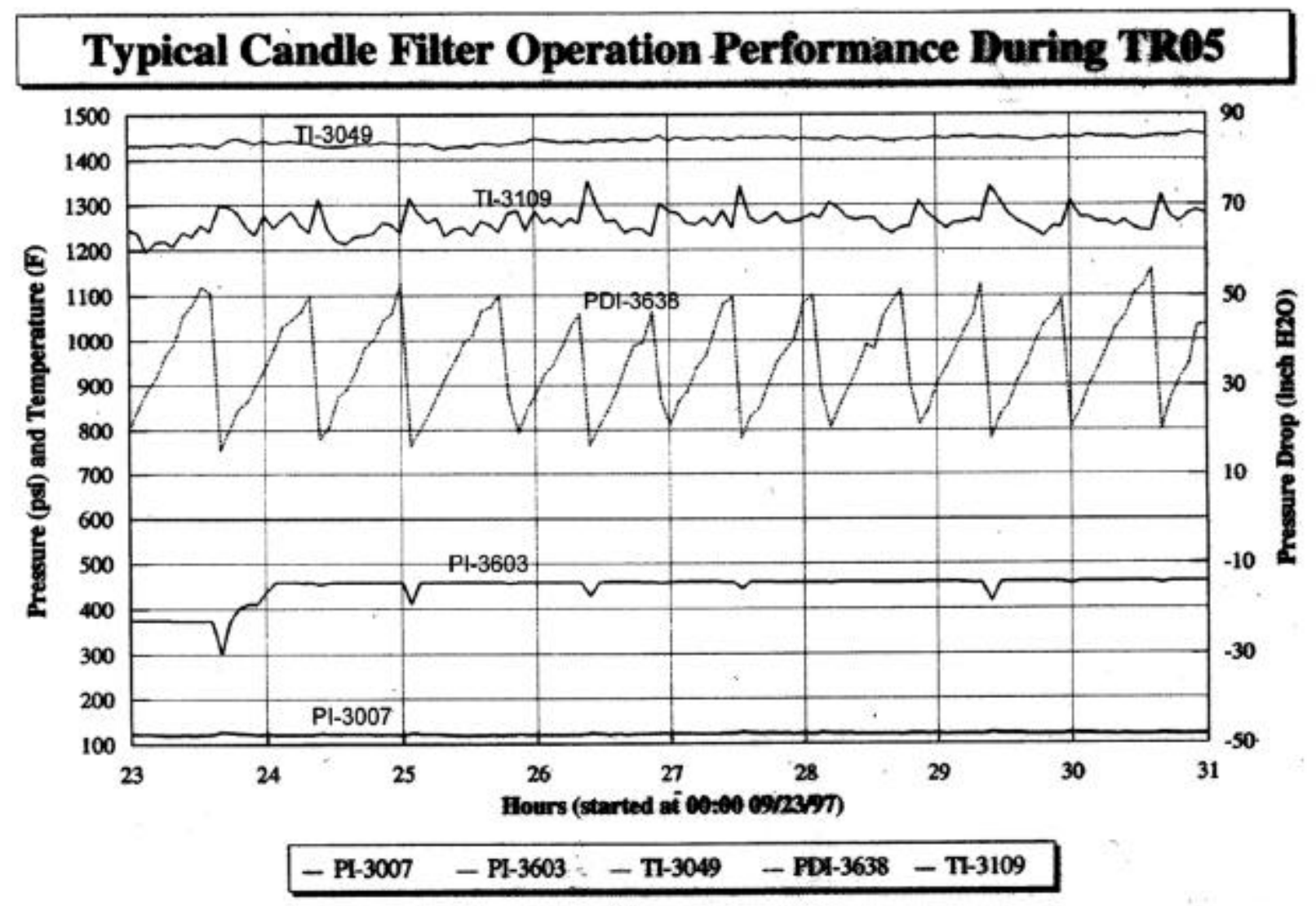

Figure 4.3 Typical Filter Performance During Test Run TR5 (22 Candles) 


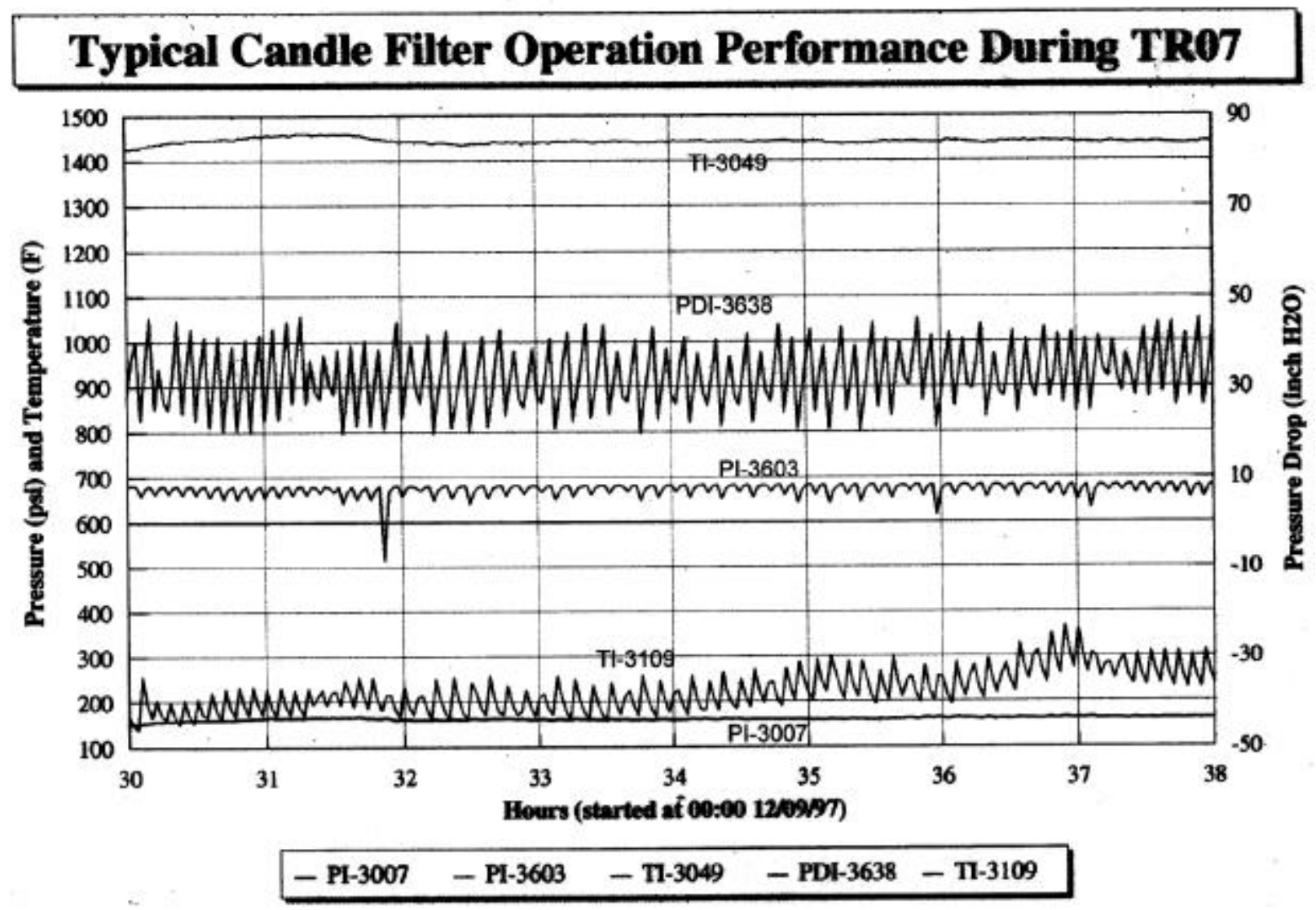

Figure 4.4 Typical Filter Performance During Test Run TR7 (10 Candles) 
In the 10 candle run the pulse pressure was about 525 psi over process, the cleaning pulse was triggered at about 40 in. of $\mathrm{H}_{2} \mathrm{O}$, and the candle pressure drop after cleaning was about $25 \mathrm{in}$. of $\mathrm{H}_{2} \mathrm{O}$. In both runs TI 3109, which is a thermocouple located in the $6 \mathrm{in}$. solids drain nozzle at the bottom of the unit, registers the expected temperature spike with each cleaning pulse as the dislodged cake drains from the unit. The most significant difference between the runs is the frequency of cleaning. With 10 candles the filter was pulse cleaned about 9 times per hour versus 2 times per hour with 22 candles. Although the former frequencies are high from the standpoint of long-term operation, they could have been reduced by raising the trigger pulse cleaning pressure differential to a more reasonable level of about 90 in. $\mathrm{H}_{2} \mathrm{O}$. Recognizing that test runs TR4 through 7 were of relatively short duration, no filter blinding was experienced and there appeared to be no significant increase in the candle after pulse cleaning pressure drop even after withholding cleaning for one hour. 


\subsection{Conclusions/Summary}

The Kentucky No 9 coal and Florida limestone proposed for use in the Lakeland $2^{\text {nd }}$ Gen PFB Demonstration Plant were tested in the Livingston carbonizer pilot plant. Four relatively shortterm test runs were conducted, and they showed the feedstocks posed no obvious operating problems to the carbonizer or its ceramic candle filter. In the first two runs a fine limestone feed size $(\mathrm{d} 50 \approx 150 \mu)$ recommended for the PCFB boiler was used, whereas in the second two runs a coarser minus $1 / 8$ in. feed was employed. Since the carbonizer was operated on a once-through basis (no recycle of elutriated fines back to the bed) most of the fine sorbent elutriated and left behind a predominantly char bed. With less sorbent in the bed, the fine feed sulfur capture efficiency was less that that of the coarse feed (about 931/2 versus 95 per cent); and the coarse feed size $1 / 8$ " x 300 micron is recommended for the Lakeland demonstration plant carbonizer.

Agglomeration was experienced in the carbonizer during the tests, and it was initially thought to be caused by the lack of sorbent in the bed with the fine feed. When agglomeration was also experienced in the first coarse limestone run, an examination of operating data traced the cause to inadequate fluidization around the feed pipe. By raising the velocity to $2 \mathrm{ft} / \mathrm{sec}$ in the drain annulus that surrounds the feed pipe, agglomeration was eliminated.

The carbon conversions and gas yields observed in the tests agreed with values predicted by Foster Wheeler's proprietary carbonize computer model; this model is also being used to predict Lakeland plant performance. A portion of the coal nitrogen that is released in the carbonizer is converted to ammonia. Previous testing has shown this conversion to be a function of the feedstocks and operating conditions. Ammonia conversion with the Lakeland coal and limestone ranged from 6.7 to $22.5 \%$ of the coal nitrogen released in the carbonizer.

Pilot plant tests were also conducted to determine what increases in sulfur capture efficiency could be achieved by the injection of zinc oxide into the carbonizer syngas upstream of the candle filter. The tests were conducted with the Lakeland 1.4\% sulfur Kentucky No 9 coal and limestone; the pulverized zinc oxide was injected as a 5 to $15 \%$ by weight water slurry into the gas stream at the top of the carbonizer. The tests showed that large water injections can cause sulfur, already captured as calcium sulfide, to be re-released to the syngas from entrained particulate matter and the ash cake in the candle filter. Despite this effect, with 15 weight per cent zinc oxide slurries it was possible to increase the carbonizer sulfur capture efficiency from $93.7 \%$ to over $98 \%$. Although this was achieved at a $\mathrm{Zn}$ to syngas sulfur molar feed ratio of 6.5, lower feed ratios would be required if higher slurry densities or dry feeding zinc oxide feeding systems were to be used.

Gas turbine limits on vapor phase alkali levels are in the parts per billion range and, because low alkali levels, high temperatures, and high pressures are involved, these measurements are difficult to make. Using an extractive probe that was designed and supplied by WSTC together with their laboratory handling/analyses procedures, alkali measurements were conducted by Foster Wheeler in the Livingston carbonizer pilot plant. The measurements were made downstream of the ceramic candle filter with the carbonizer operating with the temperature and feedstocks (Kentucky No. 9 coal and Florida limestone) planned for the Lakeland plant. The vapor phase alkali levels measured with the WSTC probe decreased, as expected, with 
decreasing gas temperature. Even though the alkali levels were very low, the temperature trend exhibited minimal scatter and the data indicates carbonizer syngas alkali levels should be less than 20 ppbw at $1200^{\circ} \mathrm{F}$, a value that should be acceptable to a gas turbine.

The ceramic candle filter operated at about 1300E F. During the first two runs, the filter operated without a pre-cleaning cyclone, and to accommodate the higher solids loading a $1.9 \mathrm{ft} / \mathrm{min}$ candle face velocity was used ( 22 candles were installed in the filter). In the second run, a pre-cleaning cyclone was installed, and the face velocity was increased to about $4 \mathrm{ft} / \mathrm{min}$ by reducing the number of candles to 10 . In all four runs the filter performed successfully showing no signs of blinding, bridging, or ash hopper agglomeration. 


\subsection{References}

3-1 E. Kurkela et al, "Pressurized Fluidized Bed Gasification of Wood, Peat, and Coal Reseach at Otaniemi PFBC/G Test Facility", publication source unknown

3-2 A. Robertson, et al., "Conceptual Design and Optimization of a Second Generation PFB Combustion Plant,” Report DOE/MC/21023-2825, Vol. 1, Phase 1 Task 1 Topical Report, Prepared by Foster Wheeler Development Corporation under DOE Contract DEAC21-86MC21023, September 1989.

3-3 Y. Daijou et al, "Alkali-Vapor Measurements in the Wakamatsu PFBC Plant", Proceedings of the $14^{\text {th }}$ International Conference on Fluidized Bed Combustion, Vancouver, 1997

\subsection{Bibliography}

None Required

\subsection{Acronyms and Abbreviations}

ACFM Actual Cubic Feet Per Minute

ID Inside Diameter

$\mathrm{H}_{2} \mathrm{~S} \quad$ Hydrogen Sulfide

$\mathrm{NH}_{3} \quad$ Ammonia

PCFB Pressurized Circulating Fluidized Bed

PFB Pressurized Fluidized Bed

SCE Sulfur Capture Efficiency

WSTC Westinghouse Science and Technology Center

$\mathrm{ZnO} \quad$ Zinc Oxide 